UC-NRLF

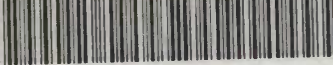
B 3271868

\title{
THE HERON OF
}

to:

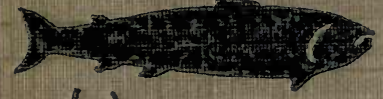

145

$+3$

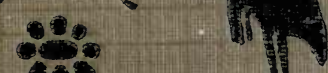

60
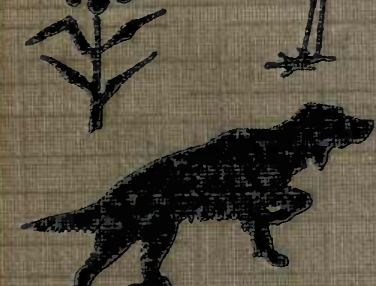

11

$b^{2}$
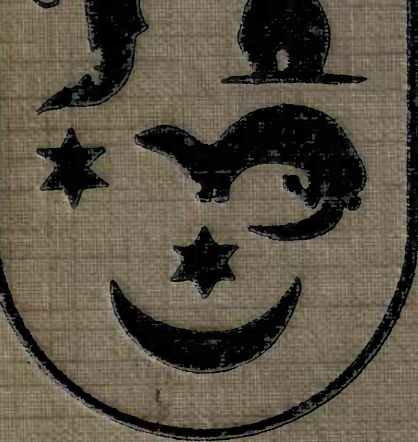

ALFRED W. REES 

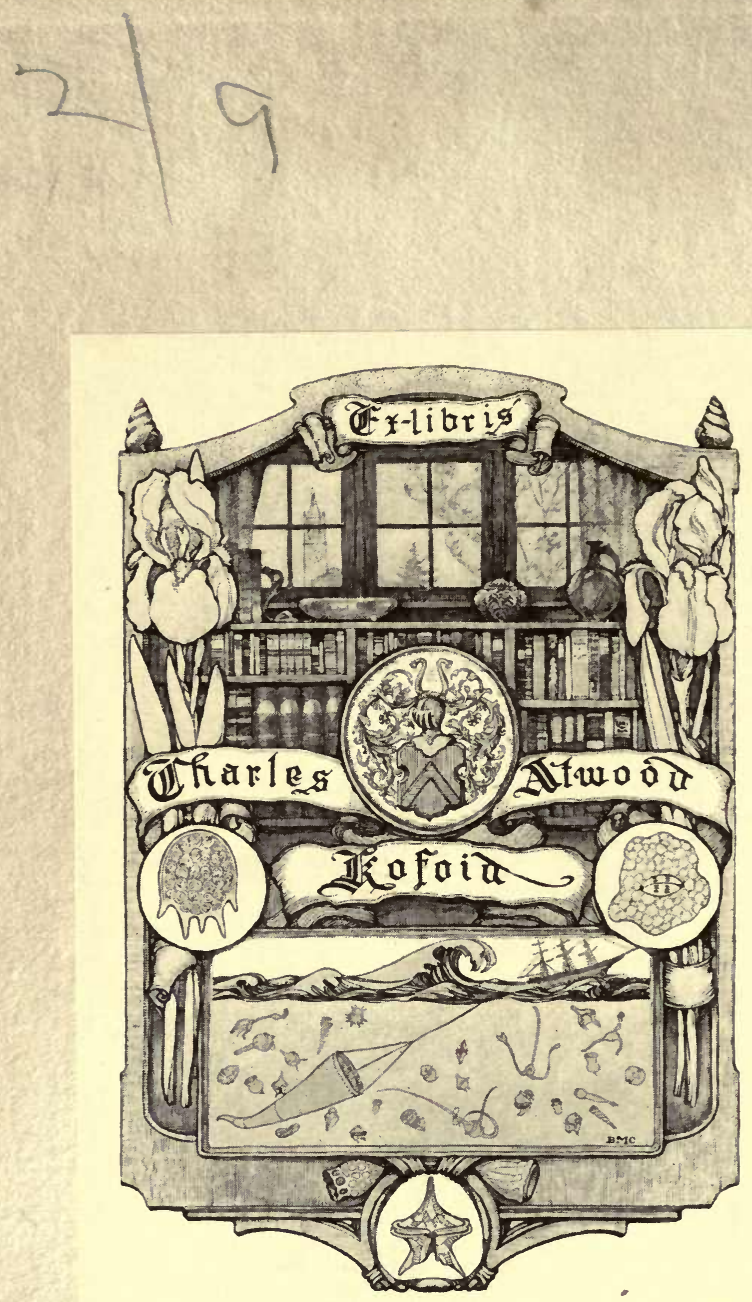


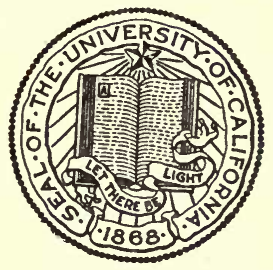

THE LIBRARY

OF

THE UNIVERSITY

\section{OF CALIFORNIA}

PRESENTED BY

PROF. CHARLES A. KOFOID AND MRS. PRUDENCE W. KOFOID 



\section{THE HERON OF CASTLE CREEK}




\section{BY THE SAME AUTHOR}

\section{IANTO THE FISHERMAN AND OTHER SKETCHES OF COUNTRY LIFE [Out of Print.}

The Times. - "The quality which perhaps most gives its individuality to the book is distinctive of Celtic genius. . . . The characters . . . are touched with a reality that implies genuine literary skill."

The Outlook. - "This book - we speak in deliberate superlative-is the best esșay in what may be called natural history biography that we have ever read."

\section{CREATURES OF THE NIGHT} A BOOK OF WILD LIFE IN WESTERN BRITAIN With Illustrations.

The Times. - "So graphic is Mr. Rees' writing, the reader himself feels one of the company, crouching in the brushwood in the moonlit wood, as a crackle of twigs or a glint of light makes the stealthy motion of otter, fox, vole, hare, or badger .... these pictures of them, in conditions so seldom described, form engrossing reading for all who love the wilder aspects of nature."

\section{LONDON : JOHN MURRAY}




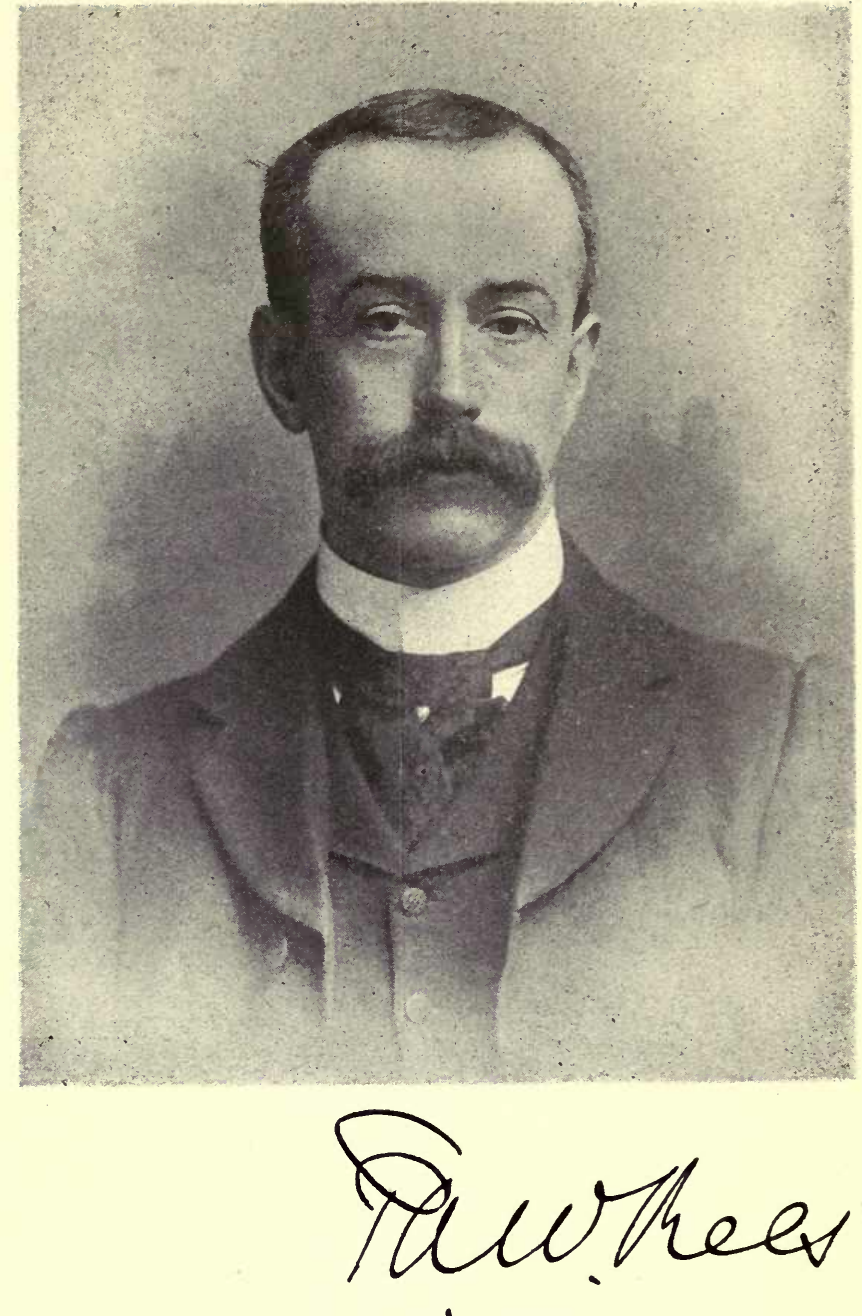

Photo by J. Russell \& Sons. 


\title{
THE HERON OF CASTLE CREEK
}

\author{
AND OTHER SKETCHES OF \\ BIRD LIFE
}

BY ALFRED WELLESLEY REES

WITH A MEMOIR OF THE AUTHOR BY J. K. HUDSON AND A PORTRAIT

\section{LONDON}

JOHN MURRAY, ALBEMARLE STREET, W. 1920 



$$
\begin{gathered}
k-Q L 673 \\
R 38 \\
\text { Bul } \\
\text { Lib. }
\end{gathered}
$$

To

"GEORGE" AND "ESTHER"

IN MEMORY OF

$$
\text { "PA" }
$$


"My birds, come back! the hollow sky Is weary for your note, (Sweet throat, come back! O liquid, mellow throat!) Ere May's soft minions hereward fly, Shame on ye, laggards, to deny The brooding breast, the sun-bright eye, The tawny, shining coat."

Alice Brown. 


\section{PREFACE}

TTHE articles in this volume were selected

1 some years ago by the author for re-issue in book form, and were partially corrected by him. Their publication was held over during the war, and owing to the author's death they still lacked his final revision. As Mr. Rees's literary executor I have prepared them for the press, and prefixed a short memoir.

The bulk of the book appeared originally in The Standard newspaper. I wish to thank the editor of Chambers' Journal for permission to reprint, in revised form, "Bird Life in a Western Valley." The chapter on the Bittern, called "A Moorland Sanctuary," appeared first in the Monthly Review (Murray). The portrait is reproduced by permission of Messrs. J. Russell \& Sons.

There still remains a considerable amount of Mr. Rees's work that seems worthy to receive a more permanent form. I trust the reception of this volume will justify the issue of another, perhaps more miscellaneous, selection.

J. K. HUDSON. 



\section{CONTENTS}

Memotr of the Author . . . . . . 1

The Wood-Wren . . . . . . 19

The Home of the Willow-Wren . . . 42

Misadventures of Bird-Watching . . . 52

Bird Life in a Western Valley-

I. The Kingfisher $\quad$ • . . . . 67

II. The Heron . . . . . . 74

III. The Dipper . $\quad . \quad$. $\quad . \quad . \quad$. 78

IV. The Dipper's Nest $\quad$ - . . $\quad$ - 90

The Heron of Castue Creek-

I. The Wounded Heron • • . 97

II. Young Herons in Training . . . 111

A Moorland Sanctuary $\quad . \quad$. $\quad . \quad$. 124 The Partridge-

I. Partridge Nesting Habits a $\quad$ - 139

II. The Summer Life of the Partridge 152

III. Enemies of the Partridge . . . 162

IV. The Changing Year - . . 175

V. A Day with the Partridge • . 187 Wild Life in Hard Weather . • . . 197 INDEX . . . . . . . . . 217 . 

MEMOIR OF THE AUTHOR 



\section{MEMOIR OF THE AUTHOR}

\section{TTHOMAS ALFRED WESLEY REES, the "Alfred Wellesley Rees" of Ianto the}

Fisherman and Creatures of the Night, was born December 7th, 1872, at Pembroke Dock. His father, Richard Rees, was in the employment of the Admiralty as a Government Inspector of Iron Contracts, and is described by his eldest son as "a man of decided and admirable character; he was an unpaid preacher among the Wesleyans, and one of the best preachers I have had the good fortune to hear." His mother was a Wilkins, belonging to a mid-Glamorgan stock. While he was therefore of Welsh blood on each side, he belonged both by ancestry and upbringing to the English-speaking fringe of South Wales, ruled in early days by Norman families, and here and there colonised by Flemings.

Of his two brothers the eldest was a banker, and the second a Wesleyan minister; both were of strong literary tastes, and acquired libraries alike remarkable in extent and rich in rare books 
and manuscripts. Alfred, the youngest of a trio of exceptional ability, had affinities with each. He started his career as a banker, and became subsequently a clergyman; he possessed an instinctive love of literature, especially of clear, balanced, and euphonious prose-writing; and he gradually developed in his own work a literary style which won him, to quote the words of a critic of his first book, "a place which was all his own in the great succession of writers who have made Nature their theme."

Alfred Rees received a sound education at a good private school at Pembroke Dock; but his interest as a boy lay mainly in natural history. $\mathrm{He}$ "would come home, hauling out of his pockets snakes and toads and all kinds of living things - to his mother's great horror." His brothers collected books; he, like many another boy, collected birds' eggs, butterflies and moths, and he arranged his collections with a care, thoroughness, and artistic finish worthy of a museum. He showed thus early that passion for perfection which distinguished him in the various pursuits-and these, as will be seen, were many-in which he afterwards engaged.

At the age of about sixteen, he entered the service of the ill-fated National Bank of Wales, 
and in 1891 was put in charge of the suboffice at Llandyssul, Cardiganshire. This is the village of which he wrote so much and so lovingly; the beautiful country surrounding it forms the background of most of his nature studies; here he found the human types, which he developed and idealised in "Ianto" and "Philip"; and here, while yet a stripling, he married. His two children are the "Myfanwy and Morgan" to whom his second book was dedicated. Llandyssul, for weal and woe, had a decisive influence on his life. It opened up to him many new interests; unfortunately these came to engross a disproportionate amount of his energy, and his bank work grew increasingly distasteful.

The River Teifi has excellent trout and salmon fishing, and was at that date much less closely preserved than at present. Rees threw himself, heart and soul, into the sport of angling ; and he added to the practical and traditional lore, taught him by "Ianto," all that he could glean from books, and all the suggestions of his own thought and close observation. In autumn and winter he turned to shooting with the same intense ardour. Here his quickness of sight and movement stood him in good stead, and he became one of the best shots in the district at birds and rabbits, as also in clay- 
pigeon matches. His evening pursuits included - the observation of ants-in which he followed and verified Lord Avebury's work on the subject -and billiards, a game in which he quickly became proficient. In all these things he was satisfied with nothing short of the best; and there seems little doubt that he spent upon them far more money than the slender salary of a junior bank-clerk warranted, and in so far unwisely mortgaged his future. His affairs were further complicated by the failure of the Bank of Wales; the assistants, indeed, were mostly retained by the Metropolitan Bank, which took over from the bankrupt concern; but Rees, like many others, lost his invested capital.

In 1896 he was transferred to Swansea, where he spent the next five years of his life. Here his opportunities for sport were much restricted, but at the week-ends he found in the Gower peninsula fresh fields for natural history work. He also had drawing and painting lessons, and attained considerable skill in each branch. It was at this time that he began to try his powers as a writer. He kept careful diaries of his nature rambles, and on solitary walks constantly amused himself by literary " phrasemaking." He had the usual experience of the novice in writing. His business training led him 


\section{MEMOIR OF THE AUTHOR}

to keep a record of his articles - the order and date of composition, the titles, the various papers and magazines where they were offered, rejected and finally accepted, and the prices received (or sometimes not received). Ultimately his work found regular acceptance, first in the Evening Standard, and later in the Standard, then under the editorship of Mr. G. Byron Curtis. When, in 1901, he returned to Llandyssul he was under agreement to supply the Standard with an average of (I believe) three articles monthly at special rates.

His second period of residence at Llandyssul opened with bright prospects. The bank had constructed new premises, and the agency was now turned into an independent branch. Rees was the youngest manager in the service. In addition to salary and house, he was now drawing a regular income from his journalistic work and had ample opportunity for the pursuits he loved. But even in this short space of time much was changed. Formerly Dol-llan, the house across the river, had been rented by a keen and widely-travelled sportsman, who remained one of Rees's life-long friends; but the house was now empty and its upper garden -the "ruined garden" of Ianto-had become a tangled wilderness. "Ianto" himself, his old river companion and tutor, was dead. Rees's 
own outlook on life and nature was also changed. The sportsman's instinct on a fine day "to go out and kill something" was rapidly dying out in him; he preferred rather to watch the habits of living birds and animals, and to divine their instincts, feelings, and actions. At a meet of fox-hounds, harriers, or otter-hounds, he would follow every movement with keen zest, but his sympathies turned more and more to the side of the quarry, rather than to that of the hunter. When he went shooting, he now cared little about the size of his " bag" ; his joy was rather to watch the working of the beautiful dogs he had himself trained, to note the haunts and movements of the birds, and to watch the everchanging aspects of sky and landscape. In spring he was content to go day by day to the "island" below the village, or to the river bank opposite; to sit and watch the nesting birds; to think and dream.

All this was reflected in his literary work. A vein of tender sentiment was there revealed, which seemed strangely at variance with his earlier character, and with the boisterous fun and high spirits aroused in him by the company of those he knew well. And the change went deeper. The careless scepticism of his youth passed slowly away, and was replaced 
by a growing sense of religion. Ultimately, though here I anticipate the order of events, he resolved to take orders in the Church of England.

Among other activities of this period may be mentioned photography and amateur acting. $\mathrm{He}$ designed proscenium and scenery for the County School of the little town, painted the scenery with his own hands, and inaugurated its use by organising a performance of Caste, in which he played the part of old Eccles with marked ability. He was henceforth known as " $\mathrm{Pa}$ " to his old associates in the play.

At one time he thought of devoting himself entirely to literary work, but was strongly urged by Mr. Curtis not to do so. In spite of this, he resigned his position in the bank in July, 1904. Misfortunes quickly followed. Before the end of the year the Standard newspaper was acquired by Mr. (now Sir C. Arthur) Pearson, in the interests of the Tariff Reform movement. Mr. Curtis and nearly all the staff resigned. Gradually under the new management Rees lost that position as a regular contributor which was now his chief source of income; and finally he resolved to take orders.

In 1906, after a strenuous period of prepara- 
tion, he entered Lampeter College, where he spent two years, at the close of which he emerged as the best man of his year. Professor Hugh Walker has written the following appreciation of his Lampeter career :

\section{LAMPETER, 13 th July, 1919.}

Mr. T. A. W. Rees matriculated at St. David's College in October, 1906. At that time I had read none of his writings, but I knew that he was the author of a volume published by Murray, and I looked forward with interes to his essays. They were at first so feeble and so illexpressed that my interest in Rees's writings withered and, as I believed, died. Towards the end of his first term, however, a friend handed me Ianto the Fisherman and asked me to read it. I took the volume without enthusiasm, sat down by my fire and began to read. At once I was fascinated, and I read on without a pause until I had finished the book. I naturally asked Rees for an explanation of the singular fact that for me he wrote drivel, and drivel that could hardly be called English of even the humblest sort, while in his published writings he showed himself not merely an accomplished naturalist but a master of style. His reply was that when he wrote Ianto the Fisherman he chose his own subject, wrote in his own study and was undistracted by the slightest noise. The College essays were of the nature of exercises in the art of being examined. The subjects were dictated, the men were gathered together 


\section{MEMOIR OF THE AUTHOR}

in large rooms, and they shuffled, fidgeted and turned this way and that in the search for ideas. They did not always find ideas themselves, but they effectually scattered those of the solitary student. Neither by word nor by tone did Rees suggest a complaint. I am confident that he never challenged the justice of the judgment which ranked him for a time among the least competent of his fellow-students; and he never shirked a task which must have been odious to him, as a weaker man might have done. His good sense showed him that if he was to end his College career with credit he must learn to write under the conditions which he then found so distracting. He had his reward. Very soon he mastered his difficulties, and long before the end of his period of residence he was decidedly the best essayist in College. The calm acquiescence with which he accepted the conditions under which he had to work was characteristic of the man as I knew him. In the same spifit he faced all his difficulties, and he conquered them with equal completeness. In his final examination his work was pronounced by the examiners to be the best they had seen. He had in the meantime taught his fellow-students to be proud of him; at least he had taught the more generous of them, for there were $a_{b}$ few who were petty enough to feel their own dignity diminished by his superiority. He had also shown that he was scarcely less a master of the art of speaking than of that of writing. Feeling that the time was brief and that for a man whose education had been irregular there was much to do, he seldom allowed himself to go outside the curriculum; but once he gave to one of the 
students' societies a lecture on ants, as delightful in expression as it was rich in knowledge. This gift of speech of course stood him in good stead after he was ordained. "The people hang on his lips" were the words of his first vicar to me.

As a man of mature years, and married, Rees naturally, in some respects, stood outside the circle of students. But he was far too human to separate himself from them completely. He was even willing to play the boy on occasion. There was no hint of condescension in his attitude to them, no air of superiority, though the superiority was real. I do not think that he readily made friends, but he was most loyal to those whom he admitted to his heart. He knew that I liked him and admired him and meant well by him, and he was acutely pained on one occasion when he believed that he had quite unwittingly done me an injury. Even if he was right, I fear that I had beforehand injured him at least as much by the emphatic expression of my opinion of him. It is easy to forget that some sprats imagine themselves to be the peers of whales and resent the blunt assertion of the fact that they are considerably smaller. But if men of mark almost inevitably stir envy and jealousy in the mean, they have their reward in the admiration of bigger souls. I have already quoted the generous words of Rees's first vicar, and I know that this hearty appreciation was not confined to the vicar. I had been instrumental in placing Rees there, and a neighbouring vicar, aware of the fact and admiring Rees, asked me to send him "a curste like Rees." I was obliged to own that it was quite beyond my 
power to do so. In my long experience of Lampeter I have known some very able men, but only one Alfred Rees-only one man capable of writing Ianto the Fisherman.

To this I may add that Rees's method of composition was peculiar. He would sit down with pencil and large sheet of paper, and compose slowly, writing a neat but extremely minute hand, with the lines very close together. Corrections, deletions, transpositions followed, till each sentence was moulded to his fastidious liking. The final result was sent to his unfortunate typist to decipher! Professor Walker is not quite right in saying he required absolute quiet for his work. He would often write with two or three others working and talking in the study, though doubtless it was less easy for him to do so; but he rather prided himself on his power of concentration. Later on his sermons also were often written in similar conditions. The difficulty with his college essays was largely, I think, the limit of time; he was accustomed to brood slowly over his subject, and at first probably found himself with about ten minutes to go, and nothing yet done. Hence a rapid rush at the end, and"drivel"! 
After leaving Lampeter, in 1908, he served as a curate for four years at Holy Trinity, Oswestry, and for a similar period at the parish church, Bowden, Cheshire. My own last glimpses of him were at this place. A holiday at the seaside, spent largely in sea-fishing with rod and line, had aroused afresh his old love of angling. All his spare moments during his last winters here were spent in contriving and making all kinds of ingenious tackle for the sport.

Now, as ever, he flung himself with all his extraordinary energy into his new work, and immediately made his power felt in the multifarious activities of a busy parish. In particular he won recognition as a preacher; but as a writer his work was over. No time was available, though he looked longingly forward to resuming it, when, as he hoped, he should receive a country living.

That time appeared to have come when he was appointed in 1916 to the living of Exmoor. He entered on this with high hopes both of literary and research work; suddenly his health mysteriously failed.* In January, 1917, he

* Physically, Rees was of short, stocky build ; broad in the body, and endowed with considerable muscular strength. Doubtless he had in early life made over-great drafts on his physical and nervous energy; but, in spite of occasional illness from his Lampeter days onward, no organic disease was suspected. 
consulted a specialist, who found him to be suffering from a long-standing kidney disease. Strict diet produced for a time an improvement; but in May his condition changed rapidly for the worse, and he passed away on June 11th of that year. A friend who was with him at the end writes: "In the short time he has been here he has much endeared himself to his parishioners, and in spite of ill-health he has done much in the way of bringing about better conditions of farming. . . His year at Exmoor was one of rapidly failing health. Just at first-in the height of the summer beauty-he was in a rapture of delight, and said he felt better than he had done for months. Then came the terribly long and cold winter, which was fatal to his complaint ; the loneliness and isolation preyed upon his spirits and, I feel sure, hastened the end. When I saw him in January, after an interval of five months, I was struck with the scared expression in his eyes, and with his passionate dread of another winter on Exmoor. Had he been well he would have felt differently, and Exmoor would have become to him a place of rest and adoration. After all he had the joy of a most radiant summer."

Such in brief outline was the life of Alfred Rees. In his short career he lived through more 
joys and sorrows than most of those whose span is "three score years and ten," or over. Faults he had, and he suffered much through them. His brother writes: "His strength lay in going at all hazards and forgetful of all else for what occupied his attention for the time being. His weakness was the forgetfulness of everything that did not contribute to and fall into line with the all-absorbing subject occupying his whole mind at the time." His impulsiveness and ardour led occasionally to serious mistakes and aroused enmity; and in his younger days at least he did not "suffer fools gladly." But he faced his difficulties and "dreed his weird" without whining. As Tennyson said of J. R. Green, "he was a jolly, vivid man"; and I think that on the balance the joys of his life outweighed the sorrows. Like Charles Kingsley, he lived each day to the full, and preferred to wear himself out rather than to rust. He had many talents, which he sedulously used and developed, and he spent his last years ungrudgingly in the service of others, where his duty lay. His personal friends and those who knew him only through his writings alike deplore the tragic fate which struck him down so suddenly just as he had reached a goal manfully sought for and attained. Mellowed and chastened by 


\section{MEMOIR OF THE AUTHOR}

experience, with his trained powers of observation at their height, with leisure at last at his disposal, and a new and fertile field /of work before him, he seemed about to earn fresh laurels. Then suddenly the "silver cord was loosed and the golden bowl broken" and the ardent "spirit returned unto God who gave it."

J. K. HUDSON.

Fowey, Cornwall. 



\section{THE HERON OF CASTLE CREEK}





\section{THE WOOD-WREN}

RAR up in the dark sky, myriads of tiny 1 birds sped northward from the arid plains of Africa. Ever northward, hastening to their distant homes, they journeyed through the night. Instinct guided them, as, since remote ages, it had directed their species towards the old haunts in the springtide fields and woods of higher Europe. Above them shone numberless stars from the transparent heavens; beneath them, now and again, flashed the lights of ships, or of lonely beacons on rock or shoal, placed there to guide the merchant mariners. Over the night brooded the silence of utter calm, broken only by the whir of many wings cleaving the air, or by the distant clang of a bell-buoy rocked on the waves, or by the music of the surf as it washed the shelving sands and iron-bound promontories that lay, indistinct, beneath the rolling, drifting mists. White clouds, at intervals, sailed slowly under the crescent moon, casting dark shadows along the wan streak that lay on the sea. Ever northward swiftly moved in dense array the countless host, almost the last of the 
great bird-multitudes to seek the ancestral homes. Occasionally, as if according to some careful plan, the living mass divided, as band after band broke the close ranks and shaped its course from the main line of flight. These divisions became increasingly frequent, till, as the grey dawn broke slowly in the east, most of the great valleys in mid-Europe were occupied by flocks of twittering birds.

Almost unobserved, one of the migrant armies reached the shores of Britain just before sunrise, and, after resting for a while in the woods and copses near the southern coast, dispersed in every direction, to fill with song the woodlands now almost breaking into leaf. Among our summer visitors were hundreds of wood-warblers, mostly males; the females, according to a general habit, having for a little while delayed their journey. Towards evening on the day of his arrival in Britain, one of these wood-warblers reached the island copse below our village in the west. Recognising that he had returned to the place where last year he had first looked out on the world of summer from the shelter of a snug nest hidden in the grass, he resolved to stay there, and immediately, giving expression to his contentment and delight, burst into song. He was hungry and tired and cold after his long flight from the torrid regions of the south, and 
so, when his sweet little trial song was endeda simple and unpretending song, meant only for his own uncritical ears-he set his thoughts on supper. Presently, having found the evening duns plentiful among the leafy bowers fringing the river, he retired to the blackthorn thickets in the middle of the island, and tucked his head under his wing, just as the sky was darkened in the west and the last lay of the willow-wren was hushed in the sprouting alders.

The night passed uneventfully, save that the hoot of an owl, coming from the woods across the river, caused a momentary feeling of insecurity, and a thrush in the furze-brake beneath the twig on which the warbler slept gave a false alarm, imagining that a weasel was wandering in the thicket. In the twilight of dawn the warbler awoke, but the air was damp and chill, and he did not leave his perch till the first rays of the ascending sun lit up the thatched roof of the farmstead on the hill, and the leisurely rooks crossed the valley from the elms near a lonely mansion to the dewy ploughlands where the worms had not yet descended into the lower galleries of their burrows after their night's wanderings in the open air. White clouds passed slowly overhead on the breath of a north-west wind. The leaves of the hawthorn and woodbine were half unfolded; awaiting the coming of the 
bees, the yellow flowers of the coltsfoot, asleep, drooped over their crimson stalks. The golden garment of the gorse was aglow in the slanting sunbeams.

To the wood-wren everything seemed too wonderful to be true. The old familiar sights and sounds aroused a hitherto unknown longing for the arrival of the tiny mate that was to share his summer happiness; and, as he carefully preened his feathers, he decided on a tour of inspection through the copse and the adjoining wood. Ephemerals were plentiful on the twigs and under the leaves. Yesterday had been warm and fine, and at noon a cloud of dancing insects had moved over the bright face of the river. Though the trout and salmon-pink had played sad havoc with the spent "dark blues" borne down beneath the surface of the stream, and with the cock-winged duns floating on the sun-flecked ripples, many a delicious morsel yet remained to satisfy the wood-wren's appetite. Sensitive to the gladness of spring and the charm of home, the warbler called and sang, but no sweet answering cry was heard in the bushes, though his music set all the willow-wrens atune, so that the copse was ringed with the subdued and immature strains of their sweet and wistful melodies.

Following the example of the willow-wrens, 
the robin in the hazel, the wren in his ivied retreat among the lowest branches of the hawthorn, "Silver Wings" the chaffinch on the topmost bough of a beech, sang merrily their morning songs; the thrush, forgetful of the night's alarm, piped gaily in the thick bushes around his mud-built nest. The wild, whistling carol of the dipper came from the shallows upstream, where, with snow-white waistcoat, and restless, flirting tail, the bird stood on a rock jutting out into the deep, shadowed flood at the far side of the rapids. Now and then a sandpiper, uttering a shrill, plaintive call, glanced by on pointed pinions as he skirted the island and sped from shallow to shallow.

The day wore on; the water-flies left their hiding-places under the leaves, or rose from their pupa-cases in the grass, and with irregular flights moved to and fro beneath the fringing alders on the river reach. The hovering greentail dimpled the circling backwaters as she deposited her eggs on the surface; the blue dun strayed, whirling in a film of fragile wings, towards the alder clumps; that May-fly of the mountain torrent, the big March brown, ranged swiftly from bank to bank. The island was alive with singing birds; every feathered inhabitant of wood and field seemed to have come hither for the daily feast of flies. Again and again the 
warbler sang and called, but still no answering cry was heard.

About a week had passed when, one afternoon, a flutter of grey-green wings was seen near the rose tree by the stream, and the wood-wren flew thither to find that another of his kind had come to the island copse. During the rest of the day he never for a moment lost sight of her. She was coy, and made pretence of scolding him for the ardent affection displayed as he hovered on swift-vibrating wings before the branch on which she rested. Sometimes, frightened by his boisterous attentions, she flew away, with a harsh little note of defiance; but he pursued her in and out of the bushes and tree-trunks, entreating her always, with quick, twittering voice, to live with him in his mid-stream fastness, whither no prowling cat or stoat ever came to disturb a nesting bird.

The jealous willow-wrens were fighting among themselves continually in the trees, but no rival came to disturb the wood-wren's peace of mind. His courtship, compared with theirs, was almost commonplace, and before April had gone he and his mate, after much deliberation, chose a suitable nesting-place, and in earnest began their household duties. The first hours of each day were occupied in breakfasting on ephemerals that, sleepy with cold, hid beneath the foliage. 
Afterwards, till the noontide swarm of insects burst from their nymph-cases, the warblers turned their attention to building. When the flies, enticed by the increasing warmth, drifted everywhere on frail, transparent wings, and the "plop" of rising trout came from the reaches beyond the sloping gravel-banks, the woodwrens, like the fish, made the most of their opportunity to secure a supply of dainty food. In the afternoon they were again busy about the nest. The evening was regularly given up to courtship and fly-catching. And nightly, as the misty gloom spread slowly over the countryside, they retired to sleep in the gorse near the copse.

The spot selected for a building site was a tuft of grass beneath a clump of broom on the edge of a thick tangle of briar and furze. A green, moss-covered pathway, trodden only by the cattle that in the cloudless summer days sometimes waded across the cool shallows from the farm meadows to browse in the shade of the copse, here intersected the furze-brake, and led onward to the tall avenue of beeches near the island pond, where a pair of moor-hens had their home among the sedges. Directly opposite the wood-wren's nest was an ash tree, overlooking another thicket of furze, and forming a convenient alighting place from which the birds 
could reconnoitre before dropping into cover and thence flitting straight into the nest.

Nearly every member of the warbler family loves to nest in such a situation, where insect life is plentiful, and the undergrowth is so artlessly arranged that it forms an ample screen while admitting sufficient light for the health of the young and the satisfaction of the sunshineloving parent birds. And a special tree, as a post of observation, seems indispensable to wood-wren and willow-wren alike. The warblers, whose habits are in many ways almost identical, are seldom found far from the lowlands ; for in the lush meadows, and in the brakes of fern, and briar, and furze on the borders of brooks and rivers, the insects on which they feed are hatched out in greater profusion than in the cornlands and pastures on the slopes of the hills, where the bitter winter wind, the furrowing ploughshare, and the close-browsing rabbits and sheep are never-tiring enemies to the lowlier forms of life that dwell in the grass.

Great care and ingenuity were shown by the wood-wrens in the construction of their dwelling. The moss used for a roof and foundation was readily obtainable from the cattle-path close by. When this had been moulded into shape, dry grass-bents and leaves were woven together within the dome; next, at the bottom and sides 
of the bollow, were placed fine fibres brought from the roots of plants exposed in the river bank. Then a still finer lining of hair, red and white and black, left among the thorns by the wandering cattle, was twisted into shape; and, as if to confuse the assumptions of our naturalists who tell us that the willow-wren's downy couch is never imitated by the wood-warbler, the structure was completed with a soft lining of feathers, pilfered from the disused nest of a long-tailed tit, and from the neighbourhood of a pheasant's nest in the copse.

By the second week in May all was in readiness; and the first of seven pearl-white eggs, slightly larger than those of the willow-wren, and speckled with dark reddish purple, was deposited in the hollow beneath the dome. Sometimes one, sometimes the other, of the happy pair brooded over the dainty treasures, but to their welfare the hen was more closely attentive than the cock. Her mate's chief delight lay in hunting for food, and in visiting her while, with beady eyes peeping from the open door of the nest, she sat in quiet and proud possession of her wellfurnished home. He found for her the choicest tit-bits-flies fresh from their nymph-cases, and unsoiled by rain or sun, and caterpillars, hanging by their lines of spun silk from the leaves. Often, after feeding her, he stayed to help turn 
the eggs, or to discuss, in soft twitterings, all kinds of family affairs.

Strange and wonderful were the doings of the woodland folk around that snuggery in the grass, and many an anxious moment was experienced by the brooding birds. The nest was not so completely domed as the willow-wren's on the far side of the thicket by the river front. The roof was higher, and rather less compact; and no threshold of twisted grass, as constructed by the smaller bird, lay at the entrance. The little domicile by the side of the grass-tuft might, in fact, have been better concealed. Many an incident that would have passed unnoticed had the warblers built high up in the furze after the manner of their neighbour the greenfinch, gave them serious cause for apprehension. The pheasant, whose nest was in the heart of the copse, sometimes came across the path to an ants' colony about three feet from the nest, and, scratching vigorously in search of the fat pupæ nursed within the underground galleries, caused quite a shower of earth and gravel to fall about the warblers' home, so that the little birds every moment feared disaster.

Once, in the moonlight, a rat from the riverbank stole along the path, and paused for a moment beneath the furze, sitting there on his haunches while, half believing that he had 
detected a nest wherein might be obtained a delicious supper of eggs, he sniffed the air repeatedly. But his attention was diverted by the same owl that had frightened the cock warbler just after arriving on the Island, and he scurried away to shelter beneath the hawthorns. One night, just as the eggs, grown heavy, were about to be hatched, an otter trod on the edge of the nest. The hen warbler was crouching asleep in the far corner beneath the dome. Awakened and panic-stricken by the rude intrusion, she scrambled out and flew for safety to the nearest furze-brake. But before the eggs had become perilously cool, the dawn, lightening the east, enabled the mother-bird to see that no harm had been done, and that the way was clear for her to return home. Night brought with it many unpleasant surprises, but by day nothing startling occurred; the keeper across the river had freed the island from hawks, jays, and carrion crows.

The warblers became, however, increasingly anxious as the eggs gave signs of hatching. Even the usual intervals of leisure, spent by them together at evening in the tree-tops, were shortened. The time of courtship - that holiday season of freedom and delight, when the hen bird, fascinated yet reluctant, was wont to watch her mate as he hovered for a moment overhead, and dropped on upturned wings to- 
wards her through the air, uttering meanwhile a trill of music that was more like a shy caress than a song-had passed away; henceforth family cares were to be purely and simply business, and suspiciously like irksome drudgery, but for that parental gladness which is the very breath of summer's morning.

Towards the end of May, six of the seven spotted eggs in the wood-warblers' nest hatched out successfully; the seventh was addled. The helpless nurslings - of awkward shape, with long neck, long legs, ridiculous little fleshy projections for wings, and, for head, a round ball, with blueblack protuberances where the eyes lay beneath the tight-drawn envelope of the sealed eyelidssquatted, each too weak to move, in the position formerly occupied by the eggs from which they had emerged, on the downy lining of the rainproof chamber. For some hours the fledglings lay in abject feebleness; then, with a sudden access of strength, but doubtless utterly unconscious of the meaning of the action, they craned their necks, like the buds of some strange flower with stiffened stalks, and each barbshaped beak opened to reveal a cavernous, orange-coloured receptacle for flies.

Work had commenced in earnest for the parent wood-wrens. Day by day their labours increased as the callow brood grew into vigorous nestlings, 
at first clothed with irregular patches of blueblack down, and, later, with a few pale, greenish grey feathers on head and back, leaving the down visible only about the eyes, which in time opened to the gentle light filtering through the leaves. Nature seemed to have carefully arranged the minutest details for the welfare of the birds. Though packed on the bed of the nest as tightly as goods in a bale, so that it seemed impossible, had the addled egg been sound, for the seventh midget to have found accommodation, the woodwren's family suffered nothing from the usual ill-effects of overcrowding. No dirt could cling to them, for hardly a single feather grew on the underside of their bodies while they remained in the nest; side by side they filled their allotted positions, from which they seldom, if ever, moved.

Probably because they received a more liberal allowance of food, the three near the door of the nest were perceptibly bigger and stronger than the three behind them. Indeed, the nestling that occupied the far corner, away from the light and beyond easy reach of the parent warblers, was the delicate member of the family. But kindly nature, in due time, made amends; this little bird, when his brothers and sisters left the nursery, remained at home, and for a few days, till he, too, became strong enough to 
hop out into the undergrowth, was feasted royally; for the more venturesome youngsters, scattered in the grass, were not always easily found when a nice beakful of flies had been brought from the riverside; and their portions often fell to his lot.

It is an interesting fact that a bird's nest, if built compactly, with circular walls, generally appears to contain as many inhabitants as it can possibly hold, let the number be two or ten. Many young birds, particularly thrushes, linger at home till the walls of the nest actually bulge from the pressure within; but, as a rule, when discomfort is felt, some of the fledglings become impatient of confinement, and seek more commodious quarters out of doors.

Almost immediately the young wood-wrens had broken from the eggs, a strange visitor, destined often to perplex and annoy the warblers till they became familiar with his presence, appeared on the scene. The cock-bird was removing the last of the broken egg-shells to the thicket on the outer side of the path, when the quick, irregular sound of human footsteps was heard on the pebbly shingles near the ford at the top of the island. Ever.on the alert, the warbler, having dropped the shell he was carrying into the bushes, flew to his look-out station, from which he saw that a man, having waded through 
the ford, was sitting on the grass by the stream. Presently the new-comer took something from a pouch that dangled by his side, and placed it to his eyes. The warbler, alarmed, noticed that the dark instrument was turned towards him, and immediately dived to the shelter of the undergrowth. Thence he flew to the arching spray of the rose bush that screened his nest, and, greatly excited, trilled a loud strain, apparently a song, but in reality a succession of decoy notes: chit-chit-churrrrr! chit-chit-churrrr! churrr-chit chit-chit-chit! The intruder approached nearer and nearer to the nest, till he almost stepped on its mossy dome. The hen-bird, panicstricken, flitted up on the off-side of the broom, but her exit was evidently noticed, for the intruder at once began to search leisurely in the grass. Still the loud decoy rattle continued. The cock was low down beneath the rose-tree, in a tremor of excited concern for the success of his ruse, when, to the birds' unfeigned delight, the dreaded disturber passed down the path, and sauntered along the river front, followed craftily by the anxious pair. The hen-bird was silent till her mate, thinking that his efforts to mislead had so far met with successful results, gave her a signal, which she answered by a churr-r-r, pitched in a lower key than that of her partner's music; she then returned secretly to the nest. 
The cock stayed behind, and deliberately set about endeavouring, for more than an hour, to persuade the stranger, who now stood motionless in the shadow of a hawthorn, that the nest was concealed beneath a neighbouring clump of gorse.

Presently, as luck would have it, a willowwarbler, carrying a fly in her beak, flew into an alder scarcely a dozen yards away, and the man's attention was diverted. The mothering bird, eager to feed a nestful of fledglings older and hungrier than those in the wood-wren's nest, hopped on the edge of a waving fern spray, then, heedless of danger, made straight for her nest on the ground in a low tangle of brambles, and disappeared within. Having waited for a few moments, the watcher moved across the path, stooped down, and discovered the little dwelling in the side of a mound. Seemingly satisfied, he walked back as far as the pond, and then turned along the opposite side of the island. The wood-warbler, recognising that the danger had passed, uttered a last decoy-note, half in caution, half in bravado-chit-chit-churrrr-and slipped away to his nest. From the top of the ash he saw that the watcher was preparing to cross the ford; and, as the sun went down, the woodland home was once more left in peace.

But, unfortunately, next day the intruder came again. On the same rose-bush, busily 
reeling off the same decoy signals, stood the woodwarbler, but the watcher was not to be misled this time. Remembering that a bird had flown up almost beneath his feet during his former visit to the Island, he came to the ash, and there, much to the wonder of the wood-wrens, seemed to disappear into the ground. An hour passed by, and then the hen warbler, convinced that the danger was over, flitted in and out of the broom and furze, pecking on tiptoe at stray flies hidden among the leaves, and occasionally flashing into the air, to hover for a second, and secure an insect that had been disturbed in its concealment. The furze was in full golden bloom, and the atmosphere laden with its luscious scent. Along slight, pale-green wands stood boldly out the fresher and more brightly coloured blossoms of the broom. Bees droned hither and thither, drowsy beneath their loads of pollen dust. Thousands of busy flies, transparent and silvery in the light, but with dark heads and brown legs, threaded the maze of their unceasing evolutions, ascending straight towards the treetops, then dropping suddenly, to circle and twist in the spaces between the vernal sprays bedecked with yellow blossoms. The blue eyebright dotted the sward, amid notched leaves of chickweed and dandelion, and long, slowly-waving plumes of foxtail grass. 
But almost the fairest gem in the setting of the perfect day was the little bird fluttering among the flowers. The sun shone on her as, ever restless, she moved towards the nest. From a distance she was hardly to be distinguished among her surroundings, but now so near was she to the watcher that the diverse markings of the feathers were distinctly visible. No appreciable difference could be detected in the plumage of the parent birds-pale ash-grey on the under surface of the body, inclining to greenish yellow on the throat, beneath the tail, and near the wings; olive-green on the upper side of the wings, and extending over the head to the fringe of the beak; dull flesh-colour on the legs ; dark streaks, extending horizontally beyond the eyelids, and fringing the lower side of the wing; above the eye a sulphur-yellow line.

The warbler, hunting for her fledglings' food, happened to catch an unusually large ephemeral. With this in her bill, she approached nearer and nearer to the nest, when a feeling of insecurity suddenly overcame her. Turning in the very act of alighting on the ground, she flew back to the ash-tree above the watcher's head. There she hopped lightly down from twig to twig, determined to explore the shadowed recess under the tree. Peering between the leaves, she caught sight of a grey motionless object lying in 
from the pathway, beneath an arch of broom and gorse. It gave no sign of life, so she ventured into the shadow, and for about ten minutes viewed the strange thing from every side, pretending, meanwhile, that her thoughts were entirely on fly-catching. Nothing stirred in the thicket, and the male wood-wren, grown bold, appeared on the lower branches of the broom. Gaining confidence, the female joined him. Both, nevertheless, still showed signs of uneasiness. The hen was silent; but the cock, though he, too, carried a fly in his beak, and ran the risk of dropping the morsel when he ventured to make a sound, continually uttered a soft note, imploring caution-heu-whee, heu-whee. At last, impatient of prolonged delay, the female, after a swift glance to right and left, overcame her timidity. With a flit-flit of delicate wings she darted downwards, stood before the nest door, and deposited her burden in one of the wide-open beaks uplifted at her coming. The male, without more ado, alighted by her side, and also fed the young. Both stayed for a few seconds-she within the nest, and he outsideattending to the cleanliness of the infant brood; then they flew away in different directions to search for further supplies of ephemerals. Their secret was revealed. Day after day the naturalist crossed the ford to pry on their doings, and the 
warblers wasted a deal of their time in trying to lure him away from their young.

Just as the larks on the upland pastures have each a sacred place, sometimes little more than a square yard, with a stone or mound marking the boundary beyond which no neighbour may venture unchallenged, so each pair of willowwrens, nesting along the island front, held rights over a special plot, and defied all other warblers that dared to encroach. Yet, in spite of the pugnacity of their diminutive cousins, the woodwrens, while following the disturber of their sanctuary, trespassed unhesitatingly on many a little preserve, and sometimes ran the gauntlet of a fierce-and unrehearsed attack.

As, deeply interested in the least important detail, the naturalist noted carefully their every movement, he found it hard to decide whether the wood-wrens or the willow-wrens were the most fairy-like of the tiny songsters inhabiting the island retreat. While the song of the woodwarbler was a loud trill, often repeated, the carol of the smaller bird was a varied, wistful strain of minor music that sometimes suddenly changed into a low refrain, so deceptive of direction and distance as seemingly to be uttered by a woodland singer far away. This peculiar, ventriloquial change was most noticeable when, towards evening, the willow-wren left his brood to. 
the care of the mother bird, and retired to the boughs of an alder overlooking his home. There, as the sun, from the far entrance to the gorge, flooded the valley with a glory of yellow light, the willow-wren, abandoning for a brief interval his search for flies, poured forth an incessant stream of subdued, delightful melody. The call, heu-whee, heu-whee, of the wood-wren, though almost similar to that of the willow-wren, was slightly fuller and sweeter in tone; and whereas the willow-wrens exchanged greetings when in the immediate neighbourhood of their nest, the hen wood-warbler, on visiting her treasures, seldom made response to the notes of her spouse.

Gradually, taught by experience, the woodwrens decided that the strange being who took such evident interest in their doings meant no harm, and so they relinquished much of their caution, till, one afternoon, the little ones, now almost ready to fly, were unexpectedly taken by the intruder from the nest and placed in a group on an arching branch of the broom. Something, of a peculiar shape, stood before the spray, mounted on three long pieces of wood, and covered with a black cloth, beneath which, now and again, the naturalist disappeared, before finally he moved to the side of the cloth and pressed a ball which he held in his hand. Immediately afterwards, the fledglings were safely 
returned to their home. But though the woodwrens had grown so trustful that once they had even shown the watcher how the feathery lining of the nest was partially removed to make room for the growing fledglings, this incident brought back all the old distrust, and before the following evening the young were hidden in the grass some distance from the empty nest. Obedient to their parents, they crouched motionless in their secure retreat-as lately they had been taught to remain in the widened chamber beneath the broom-whenever danger threatened, and the loud chur-r-r of warning, varied by a soft heuwhee, heu-whee, of entreaty reached their ears. They skulked, like long-legged mice, in the undergrowth, hissing audibly if alarmed, and seldom venturing aloft to the tops of the gorse and broom till, grown strong, and somewhat independent, they caught flies for themselves, and accepted the unselfish attentions of their parents only when a feeling of weariness made them disinclined for exertion. When unusually hungry, they made known their wants by low sibilant call-notes that sounded like an indrawn whistle; and, crouching before the old birds, with a pleading flutter of grey-green wings begged for the tit-bits brought to satisfy their greedy appetites. Soon the feathers appeared strong and firm on every part of the body, and young and 
old were almost alike in colour as well as in habits.

The brood continued under the supervision of the adult wood-wrens throughout the summer. The golden blossoms of the broom faded, and gave place to ripening pods. The seed clusters of the gorse dried and crackled in the sun; and the prickly, greyish green twigs lengthened on the bushes. Tall, stately rows of foxglove bells, alive with murmuring bees, fringed the thickets ; roses opened their white petals along the thorny sprays under which the father wood-wren lurked when first he tried to entice the watcher from his nest. And with the constant succession of bright flowers, unfolding and withering away, occurred an equally constant succession of gauzewinged water-flies circling over the pools and shallows of the shining river. At last, in September, when the days were shortening, the happy family journeyed together to a southern county, and thence, uniting with a vast flock of migrant birds, sped away towards a warmer land, whither the hot sun and the summer had already departed. 


\section{THE HOME OF THE WILLOW-WREN}

CERTAIN events stand out prominently in the calendar of the naturalist-sportsman; just as the middle of October marks the coming of the woodcock, and suggests the immigration of our winter bird-visitors, so the middle of May is associated with the arrival of the spotted flycatcher from the south, " the last of our migrants, a laggard." With the spotted fly-catcher the coming of our welcome woodland visitors is ended; our resident birds should then have built their nests and hatched their young. The insectivorous birds that in our northern summer find food plentiful, even for their fastidious appetites, should either be building, or about to build, the homes wherein their eggs are to be laid and their fledglings hatched, with such promptitude that autumn will witness a goodly company of fleet-winged emigrants following the sun to southern climes. The swift is by no means the first of our visitors from distant shores. The martins begin to arrive in the middle of April-the swift delays his journey till a fortnight afterwards. But his stay is short, and 


\section{THE HOME OF THE WILLOW-WREN 43}

he returns to a more congenial latitude than ours long before the swallows think of forsaking the old church in the valley. In the heights of the sky, where the swift loves to wheel his arrowy flight, insect life becomes rare when the showers of August begin to fall; and soon, on wide-spread pinions, this free, bold bird of summer takes his farewell, abandoning his nesting-place to the chattering sparrows that in winter often seek refuge in the cranny above our study window; from which, each spring, they are evicted with the unceremonious haste always displayed by the relentless, business-like swift when he returns from Africa for his brief sojourn in our valley.

The song of the willow-warbler is now much louder than when he came to us in the second week of April. Then it was hardly to be heard at a greater distance than about fifty yards from the songster, and, indeed, was not noticeable, among other bird-voices, even when the listener stood scarcely half that distance away. Frequently, in those days, when, with everything new and strange, yet evidently delightful, in his surroundings, he waited anxiously for the coming of his tiny mate, I daily watched the frail songster in his summer haunt-a thick hedgerow near the river-and grew to imagine that his actions, in some subtle fashion, were 


\section{THE HOME OF THE WILLOW-WREN}

gradually becoming an index to his thoughts, and more and more to be interpreted as such.

For a while his movements suggested little beyond an inquisitive restlessness. By day, at any rate, he was never for a moment at ease. I wondered how he could possibly fold his head beneath his wing and go to sleep when night stole over the fields, and I was inclined to believe that even in his sleep he must fidget first on the right leg, then on the left; with his head first under one wing and then beneath the other. The night would appear damp and chill after the warm zephyrs of the south, and in the deep shadows of the hedgerows the cold would be unusually severe, and the willowwarbler would feel, as we often feel when the winds of spring blow from the north-east, that discomfort followed him everywhere, and that the long-looked-for summer must yet be far away. It might be, however, that in some previous May, when the hawthorn blossoms beneath the hazels made a sweet-scented paradise of the shady hedgerow, he had opened his fledgling eyes in a dome-shaped nest carefully hidden in the grass, and not far from the spot to which he recently returned from his latest pilgrimage.

If I remained motionless near the hazels, the warbler presently became familiar, and in his intimacy ventured to give me lessons in the 


\section{THE HOME OF THE WILLOW-WREN 45}

theory and practice of fly-catching. Each twig was examined so carefully that surely not a fly in the neighbourhood could escape the attention of the fragile midget. From bough to bough, up to the highest leaf-bud of the hazels, or down in the long grass-where among the hawthorns the nut-brown wren gossiped and chattered concerning her nest in the leaves by the ivied trunk - or far out on the branch hanging over the rill, the warbler searched for spoil ; then with a faint rustle of rapid wings flew out into the sunlight and caught a stray insect that had been frightened from a leaf-bud as the bird pecked sharply at a slender twig. As he searched diligently among the hazels and willows, the warbler, on the look-out for caterpillars, peered on tiptoe into every fold of the leaf-buds, or, if he thought of flies and beetles, into every likely hiding-place between the stamens of the catkins. The shapely little head was cocked knowingly, now on one side and now on the other, as though first the right eye and then the left had a keenness denied to the other.

Occasionally, as if to vary his tiptoe curiosity and his insatiable greed of flies, the willowwarbler would pause for a moment to whisper a carol of spring; then, as if the thought occurred that even somewhere on himself a fly 


\section{THE HOME OF THE WILLOW-WREN}

might be hiding, he would ruffle his feathers and arch his neck in order to inspect his downy breast. His most humorous attitude was struck when he held his head erect, so that his beak resembled a thorn stuck in a bunch of feathers, while he gazed at the sky, or perhaps at a leaf where a fly might be seen as a dark shadow in a setting of semi-transparent green. But his song seemed to belie the fun and frolic so easily conjectured from his artless demeanour ; the low, sweet phrase betokened some exquisite sentiment beyond description, but which I almost believed that sympathy enabled me to understand.

Frequently I have been struck by this peculiarity in the song of a bird-that it indicates more than a mere exuberance of joy, more than the one simple emotion evident in a melodious call-note, and more than mere wonder, anger, expostulation in the harsh, unmusical note of alarm. This point may be illustrated by the song of the skylark. While the lark soars, circling, into the sky, his carol is a loud, bubbling trill, instinct with vigorous health, free movement, and utter delight-an evident challenge to sorrow and pain. The phrasing lengthens when he attains the zenith of his flight, and as the bird descends his song changes and becomes plaintive, pleading, questioning, till, as he drops 


\section{THE HOME OF THE WILLOW-WREN 47}

with shut wings to the earth, it ends with two or three notes the most passionate and beautiful of all. It were vain to attempt an interpretation of the skylark's carol, for it cannot be compared with the outcome of any emotion felt in the human heart. But it is, nevertheiess, akin to something that strives within us for utterance.

There is one essential difference between the outburst of the lark and the spring music of the warbler-one tells of a spirit of abandonment to be expected in a bird that loves to climb the sky towards the very gate of heaven; the other whispers of a scarcely less charming spirit of diffidence befitting a bird that delights in the seclusion of the willows and hazels near the river. The early lay of the willow-warbler is perfect in every note; nothing occurs in it to mar its wonderful sweetness. But if we would really enjoy the sweetness of the melody, we must wait and listen, and turn over its gentle phrases again and again in our mind. The song will remain with us when summer passes away.

Since his arrival in the valley, the warbler has partly changed his habits. $\mathrm{He}$ is shyer than he was when first I saw him; day by day the leafy screens are becoming denser about his retreat, and he takes full advantage of his surroundings to hide away from prying 


\section{THE HOME OF THE WILLOW-WREN}

eyes. But while more retiring, he is less selfconscious. His little mate has joined him from the south, and together they are occupied in household cares. A carefully-woven nest, made of grass and moss and leaves, and lined with downy feathers, will shortly be their chief delight. Many a journey will the tiny singer make to the home in the grass at the foot of the hedgerow, during the time when his mate sits anxiously hatching her eggs, or later, when the six white shells spotted with red have released their tiny, helpless occupants, whose constant needs become a ta $\dot{x}$ on the insect-catching abilities of their parents. Filled with the anticipation of parental pride, the warbler, grown bold in song, though still shy in habit, trills a far more perfect carol than that which I heard practised artlessly among the sprouting alders in the cold, damp days of April. His throat swells into the shape of a pouch, and the feathers ruffle out when the notes are for a moment sustained; he sings apparently in the consciousness that his great ambition in life, the care of a wife and family, is about to be fulfilled.

It is most amusing to observe this diminutive woodland songster making love to the equally diminutive object of his ardent affection. He stands on a twig in sight of his mate, and 


\section{THE HOME OF THE WILLOW-WREN 49}

assumes an almost lackadaisical air, his head held down, and his wings wide open and fluttering gently like those of a tortoiseshell butterfly, when the gaudy insect, on wooing bent, climbs over the edge of a flower. Occasionally, to break the monotony of his entreating gestures, or as if afraid that he is beginning to look foolish in the eyes of his lady-love, the willowwren stretches upwards to peck at a leaf-bud or willow-catkin ; then leisurely settles down to his love-making again, as if it were a hopeless but fascinating pursuit; while the coy recipient of his springtide blandishments answers him with a mocking, irritating call, from the neighbouring tree. Presently she flies away; and half in sport, half in earnest, he chases her in and out of the thickets with a persistency that defies her modest remonstrances, and for that very reason, perhaps, at last appeals to her secret admiration for her swift and strong-willed lover.

The willow-warbler, or "yellow wren," as he is named by the country-folk, may by that local description be readily distinguished from the many other warblers which in summer fill our woodlands with song. His sweet undertones, as of subdued and tranquil joy, with which is blended the faintest trace of regret and sorrow, are heard from morning till night as he threads his way through the thickest tangles, 


\section{THE HOME OF THE WILLOW-WREN}

or flies in and out among the upright wands that fringe the marshy places in the meadow where the kingcups grow, and garlands of wind-flowers encircle oozy beds of reed and sedge. One moment he is hidden on the far side of the bramble; the next, he reappears near by, and alights on a twig above a blaze of golden gorse. He now sings as loudly as his small voice permits; then, with a flirt of his grey wings, hops down on the bank and instantly vanishes.

Noiselessly I move towards the spot where he was last observed, for there is little doubt as to the reason of his disappearance. On my approach he flies up from the grass, and reveals the whereabouts of his nest. The cattle, when leaving their favourite drinking-pond for the fields above, have with careless hoofs torn down the turf from the bank, and at the end of one of the furrows thus formed in the yielding soil the warbler has found a depression exactly suited to his purpose. His domed nest, perfectly concealed from every casual visitor, is nearly complete ; in a few days the feathery lining will be suitably adjusted, and the first pearly egg will be deposited by his dutiful spouse. Then he will be heard singing more frequently than before; and every rival warbler in his neighbourhood will vie with him, taking up the burden of his pleasing melody the 


\section{THE HOME OF THE WILLOW-WREN 51}

instant he relinquishes it, or breaking in on his half-uttered phrase with a high-pitched, musical ripple that precisely corresponds with the beginning of his own dreamlike song.

When the first falling leaves give warning of winter's footsteps, the frail, restless little warbler will join the vast flocks of migrant birds collected near the coast, and set out across the southern seas, to find in distant countries a welcome change in food and climate. 


\section{MISADVENTURES OF BIRD-WATCHING}

A FTER some years of bird-watching, the as one of the sports of his country life. It is a quiet, unpretending sport, demanding the exercise of much patience ; and the chief drawback is that considerable leisure must be at the disposal of the watcher if a fair measure of success is to be assured. Frequent disappointments are inevitable, but these serve only to foster increasing care and vigilance, in order that the results at last obtained may preclude the possibility of doubt. The naturalist cannot but realise the value of the advice given by several of our best writers on the life of the fields-that every fact should be treated as new ; exhaustive notes should be made, and compared with those written by other hands on the same subject; and the observer should never be slavishly bound by the opinions even of recognised authorities. It will presently dawn on him how little is known concerning the habits of some of our commonest birds. He may shoot our woodland friends, identify them, measure their feathers and their 


\section{MISADVENTURES OF BIRD-WATCHING 53}

bones, and describe the colours of their plumage at different seasons of the year. He may compare and classify and theorise. But to learn much about their interesting ways of life, their " daily walk and conversation," is quite another matter, belonging to many an hour spent in the open air under spring and summer skies, and having nothing to do with the study and the midnight oil. - The reader can have but a faint idea of the charm inseparable from systematic observation of the habits of birds unless he himself has special opportunities and inclinations for such a pursuit.

Mention has already been made of frequent disappointments. I shall never forget an incident connected with my endeavours to learn as much as possible about a warbler which frequented a copse on the steep river-bank below the village. One evening I discovered the bird quite unexpectedly. Evidently she was not aware of my presence, for she flew to a bramble twig overhanging a dense tangle of grass, in a beautiful wild garden, where blue hyacinths and pink campions grew luxuriantly under the shadows of tall ox-eye daisies, and boughs laden with the snowy bloom of the "may." Thence, without hesitation, she descended into the middle of the undergrowth, evidently with the intention of visiting her nest. 


\section{MISADVENTURES OF BIRD-WATCHING}

I remained motionless for a while; then, thinking that she had settled down to brood over her eggs or her nestlings, I crept towards the bramble spray, knowing that directly I came near she would flutter up from the grass and betray the whereabouts of her nest. But I had not considered that it would be necessary to climb a difficult hedge before entering the copse. The hedge proved to be nothing less than a labyrinth of brambles, furze, hidden stakes and hawthorn branches, in the midst of which, having an eye only for the appearance of the warbler, I got hopelessly entangled, and, floundering about, fell into the torturing embrace of a myriad sinuous nettles.

On regaining my feet, the first sound I heard was the rapid heu-wee, heu-wee, heu-whit of the startled warbler that, flitting from bough to bough overhead, indicated in plain language how unmistakably suspicious was my conduct. Nor was her opinion altered when, after forcing a way back from the thicket, I danced about in the manner peculiar to one whose cheeks and hands are tingling with the effects of nettle poisoning. After half an hour's interval, during which numerous blisters had been soothed by the application of bruised dockleaves, I crept up to the hedge, and, hiding as far as possible in the ferns, peeped through 
the gap made in my struggles among the thorns.

But the warbler would not venture near her nest. She gradually moved away to the left, came back to the rose-bush immediately in front, crossed the gap, flew into the holly on the right, and, in full view, endeavoured to persuade me that her nest was in the shadow between the hazel and a guelder-rose. Then she flew across the path to the copse on the margin of the river, stayed there for about ten minutes, returned, and over and over again repeated her little deceptions.

For an hour I watched her every movement, except when the intervening foliage screened her from sight; and when she was hidden learned her whereabouts by the plaintive notes she continually uttered. Her mate came to sight only once, when he took up his position on a flowering hawthorn at the crest of the slope. $\mathrm{He}$, however, remained silent, and presently flew back to the thicket on the left.

This shyness of the male bird is not unusual, but, according to my own experience, he generally assumes the rôle of a decoy, and his heu-wee, heu-wee is heard oftener than that of the hen, while she, if his artfulness in drawing away the watcher is successful, steals to the nest, and remains there with her treasures. 


\section{MISADVENTURES OF BIRD-WATCHING}

Twilight came over the valley, and I returned home without having discovered the nest.

Next evening I went again to the spot, creeping stealthily beside the cover of the hedgerow till I was able to kneel under the rose-bush. The warblers were evidently unaware of my presence; no signal of alarm was heard though the birds flitted about the copse and occasionally perched on the bramble which apparently hung over the nest, whence they peered into the undergrowth as if to assure themselves that their charges had not been molested. Just as it appeared certain that the warblers would soon betray their secret, a bull appeared close to the hedgerow, right above the copse, and began to rub his horns and neck against the trunk of an oak. The birds, greatly agitated, tried to lure the animal away, but, taking no notice of them, he remained under the tree, and, leaning over the low bank dividing the meadow from the copse, browsed noisily on the rank herbage. In desperation I retreated towards the river, and endeavoured to drive the animal away by a cannonade of sticks and stones. But this action caused still greater alarm; and that evening like the first, passed fruitless so far as its main object was concerned.

An amusing adventure occurred on the third occasion. Not a dozen yards from the nest a 
pair of blackbirds were busy educating a hopeful young brood; and, directly I arrived on the scene, they commenced a vociferous alarm, making such use of their tongues that every furred and feathered inhabitant of the valley seemed keenly alive to an imagined danger. Needless to say, the warblers were on the alert, and the hen at once began to indulge in her favourite methods of misleading. Thinking it useless to remain in the accustomed hiding-place, I crept towards the river, and there, ensconced beneath a furze-clump, endeavoured to follow the movements of my wily friends.

The clamour of the river, raging through a narrow channel between the rocks immediately behind, drowned the heu-wee, heu-wee of the warblers ; and so, having once lost sight of them, I was unable to trace their movements by their frequent notes of alarm. I resolved, in spite of everything, to watch intently the place to which it was likely that the warblers would ultimately return; but the "everything" could hardly be expected to include the bull. After an hour of useless watching, I suddenly found that a herd of cattle had browsed towards me, headed by the patriarch, a beast of forbidding aspect, with a ring in his nose, and altogether much more formidable in appearance than he had appeared when, on the previous evening, he rubbed his 
horns against the oak tree on the crest of the slope. I beat a retreat, not precipitately, but craftily, dodging on the far side of the furze, till I gained the copse, and climbed through the gap.

But soon another difficulty arose. The bull, suspecting my presence, came near, sniffed in the hedgerow, bellowed hoarsely, and gave undoubted manifestations of a desire to clear me out of his domain. However, he eventually moved away, but, alas! only to occupy such a position that escape along the path up-stream was well-nigh impossible. To climb the slope of the copse was out of the question, for a sheer wall of rock barred any exit at the top, and on either side the undergrowth was so dense and thorny for a hundred yards or more among rugged boulders, that after trying to force a way towards the wood I gave up the attempt. The only alternative was to break cover and take the chance of a long chase down the valley; but knowing too well the unhesitating delight with which he would thunder after me, and knowing also that I should fare badly if he happened to be close behind at the hurdle-fence separating the meadow from the swamp near the corner of the glen, I abandoned that project and returned to the watch.

Lying prone on the wet grass, I once more 
turned my attention to the warblers. For half an hour nothing of unusual interest happened; but the monotonous alarm-notes indicated that the birds knew I was near, and that the utmost caution was their order of the day. At last, cramped and tired, and anticipating all manner of ills from lying in the drenched undergrowth, I rose, determined to make for home in spite of the bull. This time, happily, the enemy was nowhere visible. He had evidently gone down the bank to the ford above the cataracts; so I crossed the gap, and, taking advantage of every clump of furze and broom along the way, came down the glen; then, turning sharply to the right, ascended the cattle-path, and skirted the hay-field above the copse. There, peeping through the hawthorns, I discovered that the bull had come up from the ford, and, with head through the gap by which we had left the thicket, was leisurely engaged in an attempt to discover my hiding-place.

Next evening heavy showers came over the valley soon after I had taken my position near the copse, and thus I was doomed again to disappointment. These showers were the beginning of a week's wet weather, and on the next visit to the thicket I discovered that the young birds had left the nest.

Now it had happened that on one occasion, 
while in the valley, I noticed that somebody, half concealed in the hedgerow above the furze brakes, was following my every movement with apparently as much interest as I myself derived from prying on the doings of the woodland folk around; but as the landlord of the estate was a friend, I thought nothing of the incident, and desired only to be left in peace. A few days afterwards, however, Dan the gillie came to me with a tale. Said he, "Ieuan Ty-bach (John of the Little House) met me this morning, and told me you was a-poachin' under the wood by the farm last Wednesday afternoon, sir." "Poaching! what do you mean, Dan?" "Well, sir, he says as how you'd lost your ferrut, whatever -that she'd stuck in a hole, and you went off home without her." "What on earth are you talking about, Dan?" "You needn't be so wild, Mister; I'm sure there's been a mistake somewhere, but Ieuan said as how you was lyin' down watching the nets under the trash, and the ferrut stuck, and then you went back and fore a lot of times, but couldn't coax her out nohow. He says as he couldn't make heel or elbow of the business-why you didn't come for a day's shootin' if you wanted it, 'stead of creepin' in and out of the fern like as you was afraid to be seen workin' a ferrut. To tell truth, sir," and Dan's voice sunk into a whisper, "I 


\section{MISADVENTURES OF BIRD-WATCHING 61}

tried to stick up for yer, and gave Ieuan my mind on it. 'Why,' says I, 'you're all wrong; leastways I b'lieve so. He wouldn't go a-ferrutin' rabbits this time o' year. Most likely Mister's got a worm, or a Jinny flewog (caterpillar) that he's a-studyin' of ; that's what he's doin' under the wood.' But Ieuan says as no man would go after a worm or a Jinny flewog all that way, or he'd better go a bit further, to th' 'sylum, quick; and then Ieuan talks about tellin' th' landlord, and all that. But I says if he'd as much as breathe about you poachin', he'd put his foot in it and no mistake."

Then the truth dawned on me, and I recognised at once that it was Ieuan who had been watching from the hedge, and that it was Ieuan who had endeavoured, in his own cunning way, to stop my depredations among his rabbits by turning loose the old bull, whose antipathy for all and sundry had won him abundant respect throughout the countryside.

In this case I failed to identify the warblers, though I watched them evening after evening, spending in all probability thirty hours near their haunts. The reader may wonder at this assertion, and may express an opinion to the effect that it would be easy to obtain a satisfactory clue from some first-class book on natural history. But I am nevertheless certain 
in my own mind that all was done that was possible under existent circumstances to ascertain their species. Luck was adverse. Birds, particularly some of the warblers, are not easily identified from coloured illustrations, or from elaborate descriptions of their habits. If I had heard the male in full song, I might have instantly recognised him. Though he probably sang while I was near, he certainly must then have been out of sight in the thicket; and, had I arrived at any hasty conclusion, the very end to which my observations were directed might have been defeated. Several of the warblers make use of alarm notes that are almost identical; still, but for the fact that for the past six years I had been unable to spend my leisure, at favourable intervals, in the companionship of the birds, I might have formed an accurate idea, from some slightly distinctive sound, of the species to which the warbler belonged.

I made one careful attempt at finding the nest, but the undergrowth was matted and thick, and it seemed likely that to beat it down, or turn it roughly aside, might mean unnecessary labour and the destruction of the nest. My chief desire was to ascertain the exact point from which the hen-bird dropped into the nest; but she only once visited the spot while I was near, and that was on the first occasion, when she perched on 
the bramble spray, and afterwards, for a moment, remained with her young. Her persistent endeavours to lead me away to a safe distance occupied by far the greater part of the time spent near the copse.

While I was in durance vile, held there by the bull, the warbler suddenly changed her alarm signals into distinct calls to her mate; her voice was pitched in a higher key than before; and, making note of the change, I was persuaded that before long she would gain confidence and fly over to the bramble spray. But, after making a preliminary tour of inspection, she again pretended to be deeply distressed on account of the strange being lying still, but vigilant, by the furze brake.

Such disappointments as have just been descirbed are by no means infrequent, but birds are seldom so shy that the discovery of their nesting-place is impossible. With the warblers, and with a number of woodland birds, it is, however, an easier task to find the nest than to find the young birds which have just ventured forth into the world. The fledglings, directly they gain a little confidence in the use of their wings, are scattered about in the undergrowth, and there, in turn, each is fed by the parents. The old birds are now more than ever keenly alive to the value of secrecy, and, if they suspect 


\section{MISADVENTURES OF BIRD-WATCHING}

danger, take advantage of every available bush and tree when approaching their offspring.

In the earlier days of summer I found a whitethroat's nest among the fern and nettles at the margin of the copse. No great patience was needed for the discovery; the hen-bird descended straight towards her home from an overhanging twig, and, after she had on three occasions entered the tangle from the same spot, I was able, without treading down the undergrowth, to turn aside the leaves that screened the little domicile. When the young had grown healthy and strong, I took them out of the nest that I might carefully examine the development of their wing feathers. They squeaked harshly when first touched, and the hen-whitethroat, alarmed for their welfare, ventured close to me, and continually scolded in a loud check-checkcheck. Owing, doubtless, to this interference, the little family next day left the nest; and when, towards evening, I again visited them, they were hiding here and there in the tangle. Anxious to secure a photograph of the brood, I sought high and low, but the old birds were far too careful, and baffled me completely by entering the bushes - under which the fledglings were hiding - by one way, and leaving by another. On hands and knees I crawled into all sorts of likely places, but failed entirely to get hold of the youngsters. I was 


\section{MISADVENTURES OF BIRD-WATCHING 65}

stung by nettles and torn by thorns, and yet all $\mathrm{my}$ efforts and inconvenience was in vain. I listened intently, hoping to hear some harsh little note which would direct the search, but, warned by the persistent "checking" of the adult whitethroat, the fledglings remained quiet and motionless.

Most of the warblers, even those which build on the ground, are so overcome with inquisitiveness that they appear in sight directly their haunts are invaded. The exception to the rule is perhaps the grasshopper-warbler, which creeps through the thickets like a mouse, and is rarely seen. Unlike full-fledged birds, nestlings pass the greater part of the day in sleep, but they awake when food is brought to them. Once, before photographing a nestful of willow-warblers, I waited till, impatient at the absence of their parents, the little birds began to show unmistakable signs of hunger.' Wide-open eyes and beaks, and six tiny heads in two rows at the entrance to the feather-lined snuggery-I congratulated myself on the prospect of a pretty picture. But while the plate was being exposed, the tired little heads gradually sank into an attitude of repose, and the little beaks and eyes were shut. A meaningless blur was ultimately all that marked the centre of the developed negative, though every twig and leaf around was perfectly distinct. 


\section{BIRD LIFE IN A WESTERN VALLEY}

T FIND that as my quiet years occupied by an 1 unremitting study of wild life in one of the most secluded districts of Britain have passed, and ever and anon I have gained new ideas of Nature's purposes, my methods of observation have gradually changed. In studying certain creatures as types, I had been apt to form a too hasty opinion regarding the habits of various members of the family to which they belonged. Now, however, in each separate study of a mammal, a bird, a fish, or an insect, I am led to pursue that study to the farthest limit possible to me, even though I had already observed with care some creature nearly allied to the one engaging my attention.

But there are many creatures whose habits of life are so peculiarly fascinating - the fox among mammals, the owl among birds, the salmon among fish, and the moss humble-bee among insects may be instanced-that a preference for these is well-nigh inevitable. Without the fox, the life of the coverts and the upland fields would seem incomplete; without the owl, the 
night in the woods would be devoid of much of its appealing mystery ; without the salmon, our rivers would have far less charm than now for angler and naturalist alike; and without the humble-bee, the summer meadows in the sweltering heat of noon would seem silent and deserted.

Similarly, the dipper-the cheery, restless, white-breasted robin of the brook-is so completely at one with his surroundings that in his absence the gorge, the glen, and the low watermeadows by the mill would lose not a little of their own special attractiveness. Though the dipper is as much at home on the main river as on the tributary stream, he is more particularly associated in our mind with the dams and the leats and the purling shallows, over which the branches of the arching alders meet, than with the wide, uninterrupted sweep of salmon-pool and trout-reach where, as he stands at the water's brink, he may be mistaken, from the opposite bank, for a white pebble thrown among a number of stones brown with sun-bleached moss and grey with the natural hue of the river-bed.

\section{The KingFisher}

I have not found it so difficult to observe the habits of the dipper as those of the kingfisher, the heron, and the water-rail. Often, by accident, I come across the kingfisher perched on a 
stump or branch above the water. Long before I am aware of it he has seen my approach, and directly I pause he is gone, with a glint of topaz and emerald, through sunlight and shadow, to some distant haunt that I have not discovered. Only in summer, when he makes his home beneath a gravelly bluff where the river-bank is so steep that the path of the angler deviates for some distance from the course of the stream, am I sure of being able to watch him well during most of the long, bright day. But then I am amply repaid for all my patience as I lie hidden in the undergrowth on the bank opposite to the kingfisher's home.

The excessive shyness of the kingfisher may be the result, in this western valley, of constant persecution from sportsmen and poachers. As he flashes by on his way to some favourite pool, he seldom fails to awaken immediate curiosity and wonder. Too often, alas ! the gun leaps to the shoulder, and the radiant butterfly-bird becomes a crumpled, blood-stained bunch of feathers floating down the sunlit stream towards the ford. Afterwards, when inartistically stuffed and mounted by a taxidermist in some local market-town, he becomes the principal ornament in the gunner's best parlour; or his skin, nailed clumsily to a piece of wood and cured with a home-made compound in which pepper is a chief 
ingredient, is sold for a few pence to a village fisherman, who in time uses the beautiful feathers as the dressing of the "shoulders" of a salmonfly. Because of the kingfisher's timidity, and also because of certain of his habits, the production of a complete story of his life is beset with many difficulties. Much has been written of the habits of this bird which is wholly incorrect, unless, indeed, such habits differ to an amazing extent from those of the particular bird I have watched in his favourite breeding haunt about two or three miles from my old village.

The kingfisher, on the approach of winter, often leaves his home beside the brook, flies far away down the main river to the estuary, and takes up his abode near the fringe of the sea. There he subsists on the small fish that the stormlashed tides, receding from high-water mark, leave imprison 3 in the pools of the rocks; till with the advent of spring the heavy floods become infrequent in river and brook, and, encouraged by the increasing warmth, the tiny samlets, soon to be followed by the silvery minnows, glance again in the shallows beneath his old nesting place.

But even in summer the kingfisher's movements are not regular along the course of the stream near which he rears his family. In his flight from one point of the stream to another I 
have seen him leave a certain salmon-reach at a bend beneath the woods, and fly straight along the line marking the ancient bed of the river. Often, beside this old river-bed, I have found him sitting in lonely state on a projecting willowroot, and looking intently at his image in the placid mirror of the rain-filled hollow beneath him. I would not assert with confidence that on these silent, sunny mornings he was gratifying a personal vanity, though I can hardly doubt that birds, especially in spring, are conscious of their charms; but the pool contained not a single fish of any description, and such an expert as the kingfisher, knowing this, could not have been so mistaken as to visit the spot for the jurpose of obtaining food. Yet again, I have startled the kingfisher from his day-dreams in a certain quiet place near the margin of a tiny rill in the heart of a wood where the summer shadows are cold and dark.

The rare sight of a kingfisher engaged with his mate in teaching an eager, attentive little family of three or four how to catch fish is something never to be forgotten. Below the hole inhabited by the kingfisher, the pool is calm and deep, with a shelf of rock in midwater, and a leafless oakbough shadowing the surface just above the shelf. The spot is perfectly chosen. No inquisitive angler intrudes on the solitude; no prowling. 
otter, stoat, or weasel can climb the sheer ascent to the nest; shoals of silvery minnows wander in the summer sunshine over the shelf of rock, and from the old oak-branch the bird can watch each movement of the tiny fish.

Once, when I had crept silently into my hidingplace, I saw both parent kingfishers perched on the oak-bough. The mother was calling eagerly, yet persuasively; and now and again, from the dense shadows beneath the bushes, came a feeble, piping cry. This calling and replying continued at intervals for some time, till an odd-looking fledgling fluttered out from the shadows, and with a mighty effort succeeded in perching close by its parents. Another youngster followed, and still another, and then the family was complete.

The birds sat in a row with their heads turned up-stream. But directly the little ones became familiar with their surroundings, they-unusually hungry, perhaps, because of a long absence from their parents - sidled along the bough, opened wide their beaks, and with trembling wings begged the old birds for food. One of the parent birds, apparently the male, uttered a low, harsh $k r-r h$, and edged away to the end of the bough. The hen, however, seemed to be questioning and reasoning with her impatient offspring till, one by one, they moved to their 
former positions, and, as if in obedience to her injunctions, remained quite still and silent. Both parent birds now kept watch intently on the pool where the water flowed slowly over the submerged shelf of rock.

The male was the first to leave his perch. Quickly lowering his head, he dived with a splash into the river and disappeared, but soon came up with a minnow wriggling in his beak, and returned to his resting-place, where he killed the fish by a few smart blows on the branch. Instantly the little kingfishers, their appetites sharpened by the sight of the silvery minnow, crowded about their parent, and snatched the prize from his possession. The hen also dived from her perch, but failed to catch a fish, and immediately resumed her watch on the pool. The minnows did not reappear till all the occupants of the bough were once more motionless. In her second dive the mother bird was successful; she carried an unusually fat minnow to the bough and surrendered it to her little ones.

After obtaining a fish for the third time, she changed her methods and dropped the disabled minnow into the river just as her fledglings were striving to take it from her. One of the young birds, eager to grasp the dainty, slipped from the bough, but, fearing to enter the water, soon struggled back to its perch. Several times in 
succession both parent birds dropped the disabled minnows back into the pool, while in great excitement and anger the young birds protested against the treatment they were receiving, and failed in their persistent but feeble attempts to secure the falling fish. At last, desperate with hunger, one of the fledglings took a plunge, and came quickly to the surface with a minnow in its beak; then, failing to fly up straight to its perch, fluttered across the pool to a low alderroot, and there, in the shadow, called continually to the rest of the family. Either from pity or because they knew not what else to do, the kingfishers, both old and young, at last flew over to join the disconsolate adventurer, and soon afterwards the parents proceeded in earnest to feed their brood.

Next day, when I came again to the place, the education of the kingfishers' family seemed to be entering upon another stage. The little birds had discovered a convenient perch close above a shallow by the bank, and their parents, having perhaps taken the failures of the previous day to heart, were carrying thither minnows they had captured by diving from the old oak-bough, and were dropping them, disabled, into the ripples. Now one, then another, of the fledglings would dive in pursuit, and sometimes the three would dive together and a tug-of-war would take place 


\section{BIRD LIFE IN A WESTERN VALLEY}

for possession of the fish. Much splashing and scolding and many topsy-turvy falls lent variety to the proceedings. Carried away by excitement, the youngsters were unconsciously becoming accustomed to immersion, and were learning to use their beaks and wings with increasing strength and dexterity.

When yet again I came and watched the kingfishers' family, the lessons had so far advanced that the young birds would enter the deep water, without the slightest fear, from the oak-bough, and had fully recognised the importance of remaining motionless on their perch, instead of begging food from their parents, till the shoal of minnows, its numbers sadly diminished, rose from the deptbs of the quiet pool to play about the rock.

\section{The Heron}

The heron, like the kingfisher, escapes observation with a skill to be estimated only by the patient naturalist who has succeeded, but much more often failed, in his attempts to stalk the gaunt, motionless bird as it stood in some quiet little bay at the bend of the stream. I remember how once, when I had discovered a heron fishing in the glen, and had almost crept down to him beside a thickset hedge, a moor-hen, noisily splattering out from a ditch, gave instant alarm, and sent him away, as hastily as his great, 
cumbrous wings could carry him, to the dim distance of the up-river woods. No bird possesses a keener sight than this lean hermit of the wilds. However well the watcher may hide in the brushwood near some favourite fishing place, the bird overhead, while spying out the land before descending, will catch sight of the dread human form - the form of an enemy to the heron since the earliest days of falconry-and will pass onward till a mile of field and woodland separates him from the object of his fear. While he stands rigid in the water, apparently intent only on the movements of the minnows and the salmon-fry beneath, he is always listening and looking for the slightest indication of danger.

Last spring, however, I got the better of an old jack-heron that had baffled me by his untiring vigilance. Two of the large feathers in his tail had been permanently destroyed, and thus his flight had long been familiar to me. I had seen him in the glens and the gorges, beside the millleat near the mouth of the brook, at a pool on the main river, and even by the old Corrwg bridge about five miles from his usual haunts. I was for ever coming upon him when I least expected to do so, and when he was perfectly aware of my approach.

But one morning, as I lay in wait for the return of a timid sandpiper that I had disturbed 


\section{BIRD LIFE IN A WESTERN VALLEY}

from her nest on the shingle by the stream, the old heron suddenly appeared, flying leisurely in the direction of a fir-spinney a hundred yards or so away. He alighted quietly on one of the trees, and, as I followed his movements intently through my field-glass, I saw him feed another heron whose head was thrust up above a large pile of sticks forming a nest amid the green tops of the firs. He soon left his lofty perch, and, much to my satisfaction, headed straight towards a pool at a bend of the stream not far from my hiding-place. I waited for him to return to the wood; then stealthily and slowly, and with a watchful eye on his movements, I crept behind the bushes and made my way towards a furzeclump that commanded a view of the place where he had fished. Before I had reached the spot, however, I saw him beginning his journey back to the pool. I instantly dropped to the ground, crawled into a ditch, and lay there till he once more went to his nest; then I crept on, and gained my post of observation.

For over an hour the bird continued to visit the same place for food. While he stalked through the water-sometimes wading deeply till the current touched his feathers, and at other times only so far as to wet his claws-or, as moveless as the stones around him, stood alert for the least sign of an approaching fish, I 
watched him eagerly through my field-glass. Time after time he transfixed with his long, powerful beak an unfortunate salmon-pink; and once, among the pebbles in the shallows, he caught a big, fat frog that he immediately carried off to his mate. During his journeys to the nest I stretched my cramped limbs and altered the focus of my glasses in readiness for observing him feeding the mother-bird. At last he varied his course of action by relieving the brooding hen. She, much to my disappointment, flew away to a distant part of the stream; while I, refraining from following her, moved back to watch the sandpiper on the shingles under the beech-trees.

The heron's nest forms the centre of a wide circle, within the limits of which-to marsh or leat or river or brook-his lines of flight are frequently varied even in the breeding season. On being disturbed, he flaps away to such a distance that hours of careful stalking are often necessary before another glimpse of the gaunt, motionless bird can be obtained. I have noticed, however, that just as the bee, honey-gathering among the flowers, will, for a period, confine her attention to one species of plant, so the old heron, found "frogging" in some stagnant upland pond, will generally, when surprised, make his way to another pond where frogs are plentiful ; or, if alarmed while fishing for unwary 


\section{BIRD LIFE IN A WESTERN VALLEY}

minnows and salmon-pink at a ford, will seek a place where the conditions of water and of fishing are apparently similar.

\section{The Dipper}

The dipper has never been harassed in these western valleys to the same extent that the kingfisher and the heron have. He makes no imposing show, as the stately heron does, in a glazed case, with artificial rocks and reeds and painted background, over which the sky is a marvel of vivid blue such as only the mind of the country taxidermist could suggest. And though, amid his natural surroundings-rippling streams, and tumbling waterfalls, and many-coloured rocks and ferns and moss and trees, decked with those wonderful pearly lights and shadows which are peculiar to narrow valleys divided into swamps and islands by numerous watercourses-the dipper, with his snow-white throat, rust-brown waist, and dark-grey head, back, wings, and tail, is at all seasons a neat and dapper little fellow, his appearance is not nearly so distinguished as that of the brilliant kingfisher.

A familiar figure by the brook, as the blackbird or the wren is in the meadow-hedge, the dipper is seldom molested by the passing sportsman. Like the wren, he sings in all kinds of weather. His blithe and fearless heart is never saddened by 
the winter storm. Even when the blast is bitter as the breath of death, the stream still sings among the pebbles by the ford. Perhaps, while seeking his food beneath the surface of the water, the dipper had heard the secret of perpetual happiness whispered by the spirit of the brook -as perhaps the wren had often heard it whispered by the spirit of the wind through the patter of the hail on the withered oak leaves in the hawthorn-hedge-and for that reason is wholly undismayed. The song of the wren is, somehow, in keeping with that of the wind, and the song of the dipper with that of the waterfall; and probably,-just as the song of the wren has made that bird a favourite among the country-folk, so the song of the dipper has a bright, peculiar charm for the sportsman, who, in the secluded fastnesses along the brook, listens to the wild, twittering carol rising clear above the undertones of the breeze and the brook.

About half a mile from my home, the Lower Road beside the river turns abruptly northward, and begins a steep ascent in the direction of the moorlands. At the foot of the hill, a weaver's cottage stands near a sun-flecked brook that turns an old-fashioned water-wheel. Here all day the rhythmic clack of the shuttle mingles with the sounds of the groaning wheel, the splashing "feeder," and the rippling ford. 
I often climbed this rugged road only that I might look on the glorious landscape and enjoy the fresh, cool breezes always playing about the hill. Then, during my winter expeditions with gun and spaniel, I explored the course of the brook, and my delight was unbounded as I wandered through dingles and gorges where every turn in the path revealed a change of scenery, and I was promised opportunity for lonely summer studies of wild creatures amid conditions of life apparently unchanged through many peaceful years.

There were several reasons for the unusual variety of animal life in this valley. Among the silent, romantic gorges cultivation had never been attempted. So steep were the declivities that the burning of the gorse would have meant at least the destruction of the trees along the slopes; and frequent trimming with bill-hook and "prong" would have been both tedious and unremunerative.

Each narrow gorge was an almost perfect sanctuary for wild creatures. High pinnacles of rock caused the water from the hillside springs to divide and trickle into numerous tiny fountains along the edge of the cultivated uplands beyond. Whenever a gorge opened out into low-lying pastures, a tangled swamp was to be found on each side of the brook, so frequently had its ill- 
tended sluices overflowed on the way to mill or farmstead.

The brook-trout were too small to tempt any angler to leave the sport afforded by the main river, and as the byways of the country had little attraction for my neighbours, I was always alone when rambling through the dingles and the gorges.

After becoming thoroughly familiar with every part of the valley I seldom proceeded further than a certain spot, only about half a mile from the weaver's cottage, but difficult of access at all times to a stranger. With one exception, the numerous cattle-paths leading thither end in swamp and tangle, and this one path is not easily followed.

The perfumed breath of spring seemed to ascend like an invisible incense-cloud from the dingle far beneath, as one morning I climbed the low hedge-bank half-way up the hill beyond the cottage, and afterwards moved down the path skirting the precipitous woods towards the brook. The sounds of the feeder, the wheel, and the loom mingled in a distant monotone. Nearer, at the margin of the woods, many little cataracts hissed and bubbled. And still nearer, within the woods, where the brook reflected the sunlight between the trees, the voice of the water was subdued and tremulous, as the current rose 


\section{BIRD LIFE IN A WESTERN VALLEY}

and fell about the moss-grown stones and among the hollows of the alder-roots. Everywhere beside the path the sword-shaped leaves of the wild hyacinth were standing erect above the rich brown soil, the iris flags were lengthening, the anemones were blooming, and the earliest buds of the daffodil were beginning to assume the pendulous position in which they open their yellow cups. As the only dense shadows in the woods were beneath a clump of fir-trees near the brook, I seated myself on the dry brown "needles" carpeting the grass, where I found that I could command a view of the brook and of the slope on either side ; and where, if silent and motionless, I should probably remain unseen by the wild creatures on whose haunts I trespassed.

I had not long taken up my position in the shadows before a little wood-mouse stole out from his burrow under the dry oak leaves at the edge of the glade, and passed on his journey quite close to my feet. At any other time I might have thought that the timid mouse, continually persecuted and therefore ever suspicious of the presence of a possible enemy, had thus unwittingly paid a compliment to my knowledge of wild life; but now the breath of spring was in the wood, and the mouse, intent on courtship, had probably rid himself of his haunting 
fears and wholly surrendered himself to a subtler, more insistent influence. He had gone for some distance from his home, and much rustling and squeaking had caused me to believe that fighting and love-making were in progress among the withered leaves, when suddenly, as I turned my head towards the brook, I saw, to my surprise, that a dipper stood leisurely preening her feathers on a stone in the middle of the stream, not more than three or four yards from my hiding-place.

The scene before my eyes was one of great beauty. The brook reached away like a shining path through an avenue of trees; a steep declivity, strewn with fern-clad boulders, between which, here and there, grew stunted oaks and pines, towered from the farther margin of the stream; while on the nearer side, beyond the firs, the glade ended in a gradual slope on which were some of the stateliest beeches on the country-side. The wood, except beneath the firs, was, as I have already said, almost shadowless, for the trees had not yet opened their leafbuds; but the colours of spring were on the flowers in the grass and on the fresh green weed that, in long filaments, trailed from the pebbles on the bank of the brook; and the air was full of reinvigoration.

The dipper, unaware of my presence, showed 


\section{BIRD LIFE IN A WESTERN VALLEY}

no sign of hurry while with elaborate care she preened her feathers. Every part of her plumage seemed in turn to need her close attention; but, like the majority of the water-birds that I have been able to watch intently, she devoted most of her care to the underside of each wing, to the breast, and to the neck, where every feather, after being dried and shaken into place, was stroked out, whorl by whorl, and dressed with oil from the gland near the tail. For a little time the performance was highly entertaining; but at last the bird's fastidious repetitions failed to interest me, and I became somewhat impatient, especially as my position was uncomfortable, and afforded only a view of the stream towards the falls, and not of the nearer pools and shallows under the boulders.

I had resolved to risk detection in an effort to gain a better position, when the dipper suddenly finished her toilet. Walking deliberately off the stone, she disappeared, with a flick of her wings, beneath the surface of the stream, and proceeded to hunt for worms and grubs among the stickles and the backwaters by the bank. As for the time I was completely hidden from the bird by a projecting ledge of rock, I moved from my seat and stealthily crept towards the shelter of a bramble-clump from which an uninterrupted view of the dipper's haunts could be obtained. 
Exercising the utmost caution, I slowly gained the heart of the thicket, and there, not far from the edge of the brook, gathered about me a small heap of withered leaves which, as opportunity served, I quietly sprinkled on the briars, that I might be still better hidden while watching the water-ouzel as she searched the bed of the stream for food.

Presently a loud, ringing call-chit-chit! chitchit!-came from some distance away, and a second dipper flew straight up-stream, and alighted on the stone where, a few minutes previously, the first bird had been standing. Without delay he joined his little mate in her search for food in the shallow, and I was treated to a display such as hitherto it had never been my privilege to witness. Now and then, the birds were so close that I could follow with ease their every movement in the clear water.

They shot hither and thither beneath the surface, using their wings as fins in playful pursuit of each other; they explored the hollows between the pebbles in diligent search of worms and caddis larvæ; occasionally they pushed the stones aside, and firmly grasped them with their long, curved claws while they thrust their beaks into the gravel; then, having found the desired dainty, they quitted their hold on the stones, floated buoyantly to the top, and with 


\section{BIRD LIFE IN A WESTERN VALLEY}

evident relish gulped down the morsel before diving once more to resume their frolic and work. Each action was quick and decided, manifesting exquisite ease and the perfect adaptability of the birds to their surroundings. Whenever they tired of such proceedings, they adjourned to convenient restingplaces at the margin of the brook, where they stood blinking at the sunlight, and repeatedly twittering and curtsying to each other.

After a while the hen, perched on a mossgrown ledge, called to her mate, just as he happened to float up with a large worm in his beak from the bottom of the stream. He immediately flew towards the ledge, and offered her the dainty he had secured. As he stood in the shallow beneath her, and with gently fluttering wings begged that she would accept the titbit, and she with much show of coyness and misgiving stooped to take the tribute, it seemed to me that in the affection of these happy birds I could recognise a sentiment subtly different from mere animal passion-if such I may term the instinctive desire to which the matter-of-fact naturalist is accustomed to refer nearly all the actions of beasts and birds in the mating season of the year.

I cannot explain why it seemed to be so. In those rare brief periods of outdoor study when, 
to my surprise and delight, I have caught a glimpse of what, for want of a better phrase, might be termed the humanity of Nature, I have not merely imagined, but have felt sure, that many of the finest feelings of man-pity, sympathy, devotion, unselfish comradeshipare shared in no small measure by creatures considered to be far beneath our plane of life.

Directly his gift had been received, the dipper waded out, dived with a flourish and a splash into the deep water past the stickles, rose quickly a little way down-stream, swam to the bank, ran up the gravel, and flew to a large, round pebble well within the shelter of an alder. He shook the drops of moisture from his wings, dipped once or twice as if to satisfy himself that the stone afforded a sure foothold, then, turning so as to face the brook, poured forth a low, sweet, bubbling song, full of joy, and love, and the hope of spring and sunny weather. Having ended his carol, he flew up-stream in the direction of the gorge ; and as his last chit-chit reached my ears from the corner of the meadow beyond the wood his mate departed in pursuit.

I have seldom found a dipper far from his favourite haunt by leat and rivulet. If he has chosen the source of the river among the mountains for his nesting site, he quits this bleak spot during the winter frost and snows for the 


\section{BIRD LIFE IN A WESTERN VALLEY}

shelter of the down-stream glens and gorges; but if he has fixed his summer abode on the lower reaches of the brook, he rarely migrates, for he is sufficiently hardy to endure such changes of temperature as may there occur. Once he has thoroughly explored his chosen haunt, he resists to the utmost of his power every intrusion of strangers of his own species. It is, therefore, more than likely that a dipper coming down for the winter from the mountain torrent meets with considerable persecution, and, like an alien gipsy, is passed on under unwelcome escort from place to place till he finds a stretch of water where the rights of proprietorship are not too strictly enforced.

Almost every wild creature has its own fixed ideas of rights of privilege over a certain district about its home, and in no creature are such ideas more strongly developed than in the dipper. It would be interesting to learn, from the observations of naturalists in various parts where dippers are numerous, what is the extent of river or brook usually "preserved" by a breeding pair of these birds for their own exclusive family requirements.

As far as I myself have been able to ascertain, dippers almost invariably breed twice a year. The fledglings, directly they are well able to take care of themselves, vanish from the neighbour. 
hood of the old home; and the parents, though seldom afterwards seen feeding together, remain, till the pairing season comes round once more, in friendly possession of the reaches which served them with food for their young. Seemingly, their lines of flight reach farther on tributary brooks than on broad, quick-running rivers adjoining, where between the salmon-pools the water is shallow over the gravelly fords.

The dipper has been accused of preying on the spawn and the fry of salmon and trout, and consequently in a few districts has been unceasingly persecuted. There are undoubtedly some grounds for the accusation; the bird, finding an egg or a recently hatched fish beneath a pebble, would hardly disdain such a tempting morsel. The persecution, nevertheless, is altogether unreasonable, since the bird amply atones for his misdeeds. On our western streams he subsists chiefly on water-worms, leeches, and the caddises and the "creepers" of the stone-fly. No injury is done to the angler by robbing the trout of "bottom" food, because at all times, except in winter, "surface" food is abundant. On the contrary, the course thus pursued by the dipper is really productive of good; the trout in these localities, while they do not afford such sport with the artificial fly as on streams where "bottom " food is scarce, are occasionally induced through the 


\section{BIRD LIFE IN A WESTERN VALLEY}

depredations of the dipper to turn their attention to the March browns and the blue duns floating past the "hovers." I sometimes fear that if it were not for the dipper and other creatures as eager as the trout in pursuit of the stone-fly grubs, surface-fishing in these western streams would disturb the equanimity of the most philosophical angler that ever wielded a troutrod. The dipper is also of use to the fisherman by destroying great numbers of the nymphs of dragon-flies, which devour the spawn and even the very young fry of the salmon and the trout.

\section{The Dipper's Nest}

Soon after my long watch beneath the pines at the margin of the brook, I again visited the valley, entering at the point where the dippers had flown from sight around the bend on the outskirts of the wood. I had formed an opinion that spring was sufficiently advanced for the dippers to have nested, and that their nest would be found up-stream beyond the spot where they had vanished. If they had built, or even had done no more than choose a site, down-stream, they would, after the long intervals of feeding and playing in the shallows, have departed in the direction of the little cascades not far from the river.

This opinion was proved to be correct. For the first few hundred yards along the valley I 


\section{THE DIPPER'S NEST}

found no sign of the dippers; then, leaving the water's edge and ascending a steep, badly drained pasture, I crossed a cattle-path ankledeep in mire, turned into a copse of oaks and firs, and from between the tree-trunks gazed long and steadily through my field-glass at the brook, that, winding along the gorge far below, gleamed in the light of the sunny April day. A moorhen was feeding in the grass by the great crag at the neck of the gorge, and a few yards farther on a restless grey wagtail ran hither and thither over the pebbles.

But I could see nothing of the dippers till, after a few minutes, I laid aside my glass and searched with the naked eye the nearest reaches of the stream. At the corner beneath the scattered oak-trees, the rock had many generations ago been cut into a sheer precipice, and between the precipice and an old mossy wall the course of the brook had been deflected into a leat which opened towards the gate from a roughly built and leaky dam. In the shallows near, both dippers were busy at work, and for a time I watched them moving in and out of the ripples. Suddenly one of the birds flew off, turned the corner, alighted at the water's edge near the moorhen, rose again, and disappeared at a spot directly in the shelter of an oak-tree jutting from the crag. There, evidently, she had entered her nest. 


\section{BIRD LIFE IN A WESTERN VALLEY}

I waited on till the other bird became alarmed at a stone that I inadvertently loosened, and with a loud chit-chit sped down-stream out of sight. Then, swinging from tree-trunk to treetrunk, I descended to the bottom of the gorge, walked towards the crag, and quickly discovered the exact position of the dippers' nest. By the oak-tree's root hung a fringe of long, withered grass, and a thick cluster of polypody ferns drooped over the grey, lichen-covered base of the crag. Dead leaves, that had lingered through the winter on the oaks, and had at length been pushed away by the swelling buds, were strewn alike on grass and fern. Beneath the polypody roots, from the long filaments of which the rain had washed the soil, a number of leaves appeared to have been collected by chance while falling from the oak; but this seemingly haphazard collection really formed a ball-shaped structure -the snug, well-roofed sanctuary that my little friends had built with care and perseverance.

To approach the nest by climbing down the crag was impossible; the bluff towered perpendicularly for more than a hundred feet above the oak, and afforded not the slightest foothold. So, taking off some of my clothes, I waded into the ice-cold stream, which here spread out into a pool about three feet deep and five yards broad. When I had gone half-way across, the dipper 


\section{THE DIPPER'S NEST}

hurriedly left her home and flew along the millleat to join her mate. Standing on a slippery ledge of rock in the pool, I made a leisurely examination of the nest. It was cup-shaped and domed, and built of grass, with an outer covering of oak leaves and a lining of fine, hair-like roots of polypody fern. The opening, at first upwards under the dome, and then down into the cup, was so contrived as to be quite invisible till I stood close to the crag. Four creamy-white eggs, one much elongated and tapering to a point, the others almost spherical, lay on the soft, elastic floor of the little chamber.

Remembering how fastidious that nearest British relative of the dipper, the wren, invariably proves herself to be regarding the slightest interference with her domestic affairs, I handled both nest and eggs with exceeding care, lest possibly the rain should penetrate the loosened roof, or some other slight disarrangement occur and cause the wary birds to forsake their snuggery. Presently I moved away to a hiding-place up-stream, and there watched for the return of the dippers; but the afternoon was well advanced before they reappeared on the dam, and the mother-bird, satisfied that danger had passed, settled down again to brood on her white treasures in the little house beneath the drooping fern. 


\section{BIRD LIFE IN A WESTERN VALLEY}

Thenceforth, many of my daily rambles led to the gorge, and generally, either before noon or towards dusk, I spent an hour or two not far from the dam. The hen sat closely on her eggs, and I seldom saw her except when the morning sun shone brightly on the nest, and she came out to stretch her wings; while the cock, proud of the satisfactory progress of events, made his periodical visit to gloat over the treasures which, doubtless, he felt belonged as much to him as to his hard-sitting spouse. When the hen was brooding, the cock, however, was by no means idle. He tended his mate untiringly, brought her the choicest caddises and worms to be found by the dam, and worked and fussed as if the patient partner of his summer joys took quite an unimportant part in household duties.

In time the eggs were hatched, and during the first days after the event, while the young birds' appetites were quickly appeased, both parents enjoyed brief periods of relaxation, and were often seen far down-stream by the cascades or up-stream beyond the distant mouth of the gorge; and once or twice the cock was heard to sing the cheery carol he had practised weeks before on the pebbles in the shallows beside the dark-green firs, while the daffodils were opening and the wood-mouse ventured forth to seek his timid lady-love. The cock soon found his share 
in the task of feeding the four feeble nestlings lighter than that of providing for the hen's apparently insatiable appetite, while the hen on her part found a welcome relief from her long confinement in the comparatively light labour now falling to her share.

But holidays are brief in early summer, and before a fortnight had passed the dippers learned that family cares pressed heavily as the appetites of the nestlings increased. Seldom venturing far from home, they obtained food chiefly from the dam by the sluice and from crevices in the old wall a few yards further down the stream. At last, one morning, I ascertained that events had reached a crisis. The young birds, though unable to fly, had left the nest and were wandering shyly here and there among the ripples; while the parent dippers, with much ado, flew hither and thither, and dipped and dived and splattered in the stream, with an air of vast self-importance, as they taught their inquisitive offspring how and where to seek their food, and how to hide when a cruel hawk sailed overhead.

Another fortnight went by, and then the beetling crag near the dam no longer echoed to the oft-repeated calls of the little dipper family. All was silent in the gorge; the fledglings had taken wing to some far-distant retreat, and the parent birds, finding that food-supplies for a 


\section{BIRD LIFE IN A WESTERN VALLEY}

while had almost ceased in the neighbourhood of the nest, spent most of the day on the reaches by the weaver's cottage, till, towards the middle of May, the old home was cleansed and repaired, and again four cream-white eggs were deposited in the dark, snug chamber beneath the oak, that now displayed its first rich olive leaves at the foot of the giant rock. 


\section{THE HERON OF CASTLE CREEK}

I

\section{The Wounded Heron}

$\mathrm{N}$ a rocky eminence, near a winding creek that at ebb of tide was scarcely broader than the river flowing into it a mile above, was perched, like the gigantic eyrie of a bird of prey, the feudal Castle of an Earl. Already the ivy was climbing around the lower loop-holes of the keep, but in other places, on tower and turret, wherever it might afford a foothold for an escaping prisoner or a grip for hooks and scaling ladders, its growth had carefully been kept in check.

It was a mild, sunny day in late winter, and unusual preparations were in progress within the precincts of the Castle; the Justiciar had started on his itinerary and was shortly to visit the Earl. The drawbridge was down over the moat to landward of the creek; and wagons, filled with stable provender and firewood, with wines and meat, and with fresh rushes for the floors of halls and sleeping chambers, rumbled over the straining planks into the Castle yard. Here and there a man-at-arms or a green-gowned forester 


\section{8}

THE HERON OF CASTLE CREEK

mingled with the teamsters; and cooks and scullions loitered at the doors of butteries and cellars. A few couples of setting dogs and springers in leash followed at the heels of a falconer as he crossed the yard from the portcullis to the mews. High tide filled the creek, and boats and barges that had recently crossed the ferry lay unloading their miscellaneous freights at the water-gate.

On the grassy battlements of the keep, far above the highest tendrils of the ivy, and out of sight of the crowd in the Castle yard, stood a fair-haired boy practising archery. An old forester knelt by his side, directing him. The target, a rude straw image, with a circle painted in Norway tar for "clout," was placed at the edge of the woods on the opposite bank of the creek; and there, beside a giant beech trunk, another old forester watched the archery, and collected the arrows. Presently, when his quiver was full, he returned the shafts with ease and precision from his own bow to the archers on the keep, having first, however, tipped each barb with a small piece of wood cut from a pithy elder growing close at hand, and thus ensured that it should not be bent or blunted as it fell on the stones of the Castle roof.

Both these old foresters dearly loved the youthful archer. He, the only son of the Earl, 


\section{THE WOUNDED HERON}

was their pupil ; and, assisted sometimes by the seneschal, and sometimes by a light-hearted friar who, it was believed, knew more about sport and war than about the strict observances of the Church, they, from his earliest infancy, had guarded him, by day and by night, and had taught him how to bend the dainty long-bows they had shaped for him after the pattern and the balance of their own stronger weapons. The boy had grown adept in every martial pastime. Riding his palfrey at the miniature quintain that the seneschal had erected for him in a grassy close beyond the tower, he would rarely fail to point his slender lance aright, and afterwards elude the swinging sandbag. He could strike and ward with sword and shield as deftly as could many a wartrained squire.

Among the Earl's horses was a certain destrier that had often borne his master in the fray, but later had settled down to end his days in peace. The friar had taught the old horse to gallop, at a signal, straight from end to end of the close; then, the charger's lessons being complete, he had strapped a straw-stuffed dummy to the animal's back, and sent the youthful warrior, with spear in rest, full tilt against the effigy. Little Renoult soon loved this exciting sport far more than to ride against the quintain. The docile destrier 


\section{THE IHERON OF CASTLE CREEK}

never swerved in his thunderous career, the palfrey was obedient to the slightest sign; and, though at first the boy seldom struck the swaying effigy, misses became fewer and still fewer, till the mark was changed for the life-sized image of a knight in rusty helm and coat of mail, and with a rusty shield held slantwise beneath the visor. To hit the casque with such accuracy as to snap its light fastenings from the collarplate, and bear away the head-piece hanging by the vizor from the point of the lance, had for weeks been the boy's ambition.

But Renoult delighted most of all in the sports contrived for him by the two old bowmen who were now superintending his lessons in archery. His mother was a Saxon heiress, and his present companions had been in the service of her family long before she wedded the Earl. Perhaps, indeed, it was because of this that the Earl, a haughty Norman, looked tolerantly on exercises which, at heart, he scorned as unbefitting a youth whose weapons in the fray would be, not the foot-soldier's longbow, but the axe, the mace, the sword, and the lance. For the powerful feudal lord loved the gentle Saxon lady, and, while he rested in his Castle from the arduous service of his King, nothing pleased him better than to sit beside her in the bower, and watch the smiles that wreathed her beautiful features as 
ever and anon she gazed from the casement on the green courtyard far beneath, where Renoult with his faithful attendants was busy with his sports.

Renoult's archery highly pleased the two old men who had taught him how to bend the bow. One after another that winter morning the whistling arrows found the butt; sometimes they shivered in the "clout," and Serewulf, the marker, signalling his joy, stepped from beside the beech trunk, and promptly cut a notch for tally in a sapling ash behind the target. The boy, elated by his successes, secretly longed, as he stood upon the battlements, for some chance to prove his skill at a living, moving object. A week before, he had seen old Serewulf's deadly arrow pierce a grey wild goose that flew at utmost speed along the creek towards the open sea. He hardly believed, though his boyish selfassurance was unlimited, that he could hit a flying goose, but he kept a sharp look-out, and his favourite arrow, specially tipped by the armourer from the fragment of a dagger blade, and flighted with feathers from the bird that Serewulf had recently shot, lay in readiness on a near ledge of stone. The lesson was almost at an end, when suddenly a blue heron rounded the donjon wall, and, alarmed at the sight of Renoult and his companion, rose high above their heads. 


\section{THE HERON OF CASTLE CREEK}

Excited beyond control, the boy fitted his favourite arrow to the string, and, before the forester could interfere, aimed and sped the shaft. The heron struggled for a moment to continue her course, then flapped slowly downwards and fell in the undergrowth by the target.

In the Middle Ages the heron was game, preserved so carefully for hawking that on the great feudal manors the destruction of the bird by an underling was severely punished. If a serf, the underling probably suffered physical torture according to the barbarous customs then in vogue; if a freeman, he was banned, and to all intents and purposes outlawed from the district in which the offence occurred. Both foresters knew this, and, dreading lest they might be held responsible, as the attendants of the young noble, for the boy's thoughtless act, were instantly dumbfounded. Then Serewulf, ever resourceful, stripped off his jerkin, wrapped the wounded heron in its folds, and vanished with his burden into the undergrowth. Renoult and his companion hurriedly descended the winding stairway of the keep, sought the water-gate, pushed off in an empty boat till they gained the ferry opposite, and soon joined old Serewulf, who was leisurely examining the bird in a glade at the far end of the wooded 
stretch beyond the creek. After a few minutes' eager conversation in a broad dialect that Renoult imperfectly understood, the foresters, speaking in Norman-French, explained to the boy the position in which they were placed by his reckless archery. If he told of his deed, they, at least, would never more be present in his pastimes. He quickly recognised that he had wronged his staunchest friends, and protested, with tears, that he had meant no harm, and would on no account divulge his doings even to the seneschal or the friar.

Renoult and one of the archers presently returned to the Castle, leaving Serewulf with the heron in the glade. The archers, though they loved the boy sincerely, felt they could not rely on him to keep his recent action secret. They believed that, sooner or later, proud of his first successful shot at a bird on the wing, he would whisper the news to a playmate, or, in some moment of endearment, to his lady-mother. So, when Renoult had gone to the Castle, Serewulf again examined the heron, determined, if possible, to carry out the plans he had briefly discussed with his comrade. To his great relief he found that the bird was only slightly wounded in one of its wings; the arrow had cut through the thickest quills, and blood was oozing from the fleshy sockets of the split feathers. Concealing 


\section{THE HERON OF CASTLE CREEK}

his charge, whose pick-axe beak he had been careful to render harmless by wrapping his hose around it, he occupied himself for a while in making a coarse rope of grass. Then he bound the heron's legs and wings and beak, donned jerkin and hose, and walked away through the wood towards a corn-mill on the banks of the river some distance beyond the head of the creek. At dead of night, long after curfew, the heron was taken to the cage of a duck-decoy in the feeder, where she spent a luxurious captivity, fed by the miller with fish and all manner of dainties till her wound was healed, and the balance of her wide vanes so far restored that she was able to fly. But one of the great pinions was damaged beyond the present prospect of a new growth.

When all was in readiness Serewulf carried the heron back to the glade where, by appointment, he met his comrade and their pupil; and with great show of boyish gladness the Earl's young son himself released the bird and watched her as, wild-eyed and with ludicrous haste, she rose to the heights of the sky before flapping away in the direction of her unforgotten haunts. Thus for the bowmen ended a time of considerable misgiving. They cared little whether the boy kept his counsel or not, now that all had happened well; and their affectionate regard for 
him-affectionate, yet respectful as became their rank-was quickly renewed.

Renoult led an almost unfettered life. The Earl, famed as in every respect the greatest military leader among the Norman Barons of the day, was strict and unrelaxing in the discipline of his soldiery. Each beacon fire on the hill-tops of his broad domain was ever ready for the torch of the sentinel; the sleepless sentinel was ever ready to kindle it on the approach of a marauding band. "Watching, and in arms" was the motto on the escutcheon of this magnate of the Western Marches. Whenever Renoult wandered alone he was followed, as by an invisible shadow, by one or both of his personal attendants, and, if his rambles led far from the Castle, a troop of horse, presumably engaged in military exercises, often crossed his path or moved along an adjoining hillside. Hard, indeed, without a doubt, would it have been for the leader of that troop if Renoult had been kidnapped in a robber raid; hard, also, for the faithful foresters if wolf or boar had wrought him harm. Once, during a ramble through the woods, Renoult had happened on a rutting stag in company with a herd of timid hinds. Frightened by the threatening behaviour of the jealous beast, he had lifted to his lips the horn that, by his father's strictest orders, he on 


\section{THE HERON OF CASTLE CREEK}

his lonely excursions invariably wore strung at his baldric, and, at the first nervous note, had been surprised to see his friends the bowmen leap from the thicket and stand before him, beating off the persistent creature with their stout hog-spears.

It was, after all, fortunate for the heron that she had been wounded and imprisoned in the decoy by the mill. For, during the visit of the King's Justiciar to the Marshes, hunting and hawking had seemed to be the order of the day, and lords and ladies, with their trains of huntsmen, falconers, and servitors, had scoured the wide countryside in search of sport. Herons and bitterns, in particular, had suffered; and the smaller birds had been so often flushed and frightened that they either hid in terror or flew away with reckless speed when Renoult appeared near their accustomed haunts.

When spring was well advanced, and the leaves were opening on the forest boughs and the marigolds were blooming by the now unused decoy, Renoult's desire to wander far from home became stronger and still stronger. Out on a bright, fresh morning near the edge of a marsh along the river, he saw a heron-that, from the condition of her damaged pinion, he recognised as the bird he had shot-descending leisurely to the shores of a little lake in the 
midst of the swamp. He stole through the rushes and the alders till he reached a spot close to the lake; and thence he watched the bird intently.

She was in company with another heron, and waded hither and thither catching frogs. Now and again her mate-as the stranger ultimately proved to be-deferentially approached her and offered a frog or some other tit-bit he had just secured, which she invariably accepted with a slight display of condescension, as if his regard for her, though not exactly unwelcome, was an every-day matter of trifling importance. Renoult noted the strange, clumsy methods by which the male bird paid court-the wheeling, drooping flights, the lowering of the head and the elevation of the crest, the soft, caressing touch of the powerful beak on her slate-coloured breast, and the quick retreat as she, half in play, half in earnest, struck at him when his attentions lacked due ceremony. The Norman boy, accustomed to think of the heron as the falcon's prey, an object most particularly associated with hoods and jesses, bells and gloves and lures, the use of which had been familiar to him since his earliest infancy, found that new interest had awakened in his mind; and was possessed by a vague wonderment that the intelligent creatures before him, almost human 


\section{THE HERON OF CASTTLE CREEK}

in their free and happy ways, could possibly be sought out simply as the means of sport, offering little more than the tests of a falcon's flight, and marked for death at the very moment when the springer flushed them from the reedy mere. As summer drew nigh Renoult's love for the wild creatures in the great forest on the banks of the creek-a love owing birth to that morning on the marsh-immeasurably increased, and so absorbed him that he was seldom as happy as when he stole through the grassy glades, or over the open wastes of moor and bog, or along the banks of river and creek, his eyes alert for every movement, his ears quick to catch every note of bird and beast. But for the gaunt heron he had wounded from the Castle keep he maintained a peculiar fondness.

One place in the forest to which Renoult frequently resorted was a wild yet sheltered dingle, overgrown with furze and brambles, littered with big white boulders that gleamed among the rocks, and pastured by sheep belonging to the industrious Flemish weavers, who dwelt in neighbouring hamlets beneath the protection of their feudal lord. The young noble, wise beyond his years, felt that the perfect solitude appealed to him, suggesting ease and calm in contrast with the warlike bustle, and the preparations for feasts and sports, in- 
separable from life within the moated fortress by the creek. One side of the dingle, sloping steeply to a brook that poured in dancing torrent over the shale on a fringe of the moorland far up the valley, faced the south, and caught each ray of sunlight as in a trap of golden gorse and bronze and emerald fern. Lying amid the undergrowth near the crest of the slope, the boy could command such an uninterrupted view of every part of the dingle that not a single bird could enter it without his knowledge. Immediately beneath him, the brook flowed into a little lake, where, amid the flags and rushes, the trout glanced gaily as they rose to the incautious flies.

Like Renoult, the heron loved this solitude. But she knew far more of the trout and their ways than the boy could ever learn. Day after day the heron came to the brook; and whenever the sun shone bright Renoult watched from his retreat amid the golden gorse, till he believed he understood his wild pet's ways, and the bird seemed gradually to regard his presence with as little fear as that with which she viewed the wandering sheep amid the fern. At first her visits to the brook were frequent and hasty. She waded up or down the stream; she seldom captured a fish; chiefly her attentions were bestowed on frogs and worms. Once Renoult saw her fly away with a long grass-snake in her 


\section{THE HERON OF CASTLE CREEK}

beak to her nest, built high up in a tree not far from the mill ; and, greatly daring, the boy had climbed to the giddy height to see her four big blue eggs, that, as Serewulf told him, had borrowed their colour from the unclouded sky. Later, when again he wished to $\operatorname{climb}$, the forester had dissuaded him from mounting further than the bough beneath the nest, and from that point of view he had seen the young birds, as, hissing with fear and rage, they bent over the nest in readiness to resist his interference, while the parent herons, anxious for their fledglings' safety, and croaking their alarm, circled slowly high above the tree tops. 


\section{THE HERON OF CASTLE CREEK}

\section{II \\ Young Herons in Training}

NE midsummer day Renoult, the young Norman, walked over the Castle hill to the abbey, and thence accompanied his friend, the friar, to watch the monks fishing for their Friday's dinner in the ponds below the terraced kitchen garden. The monks were all keen anglers and enjoyed their sport with almost childish glee. Invariably, on Thursdays, they entered into competition for the biggest catch; and excitement ran high when, home at evening in the refectory, they weighed their fish, and the abbot rewarded the most successful fisher with an extra bowl of sparkling Rhenish wine. Rumour had it, said the friar, that brother Iorwerth, a monk from the mountains of Ceredigion, had on several occasions gained the prize when his catch seemed smaller than that of brother Gruffydd, a monk from Morgannwg, and the most eloquent preacher, as well as the most skilful angler, of the abbey. At last, suspicious, Gruffydd meekly asked the man from 


\section{THE HERON OF CASTLE CREEK}

Ceredigion to dress a few trout from the prizewinning dish, and lo ! in the gullet of each speckled beauty were found some round smooth pebbles, while the heaviest fish of all had swallowed a fair-sized piece of lead-such as the builders had used to cover the abbey roofrolled up neatly, like a "sinker" for the capture of the ravenous pike.

Brother Gruffydd, however, soon had cause to rue his proof of vulgar appetites in Iorwerth's fish, for when the trout that he himself had caught were dressed, the monks around him with one voice exclaimed that they would forthwith net each pond and stream, lest the abbey roof might disappear. The abbot, prompt in discipline, extended Friday's fast to Saturday and Sunday for the ingenious sinners, and, as part of their penance, caused them to read, once every hour, the chapter of the miracle of the loaves and the fishes, and furthermore instructed Gruffydd, whom he judged to be the greater rogue, to take for a text the words "five small fishes," and preach therefrom a sermon to the brotherhood on Sunday morn. This, according to the friar, had Gruffydd done, but with such little eloquence that all the listeners, from abbot to novice, dropped fast asleep, and the sound of snoring was loud and deep when the friar, returning from a visit to a sick member of the 
Earl's household, tiptoed on silent sandals through the doorway of the nave.

Renoult enjoyed the friar's story; and when the good man related how Iorwerth, determined not to be outdone, used heron's oil to flavour the moss wherein he kept his worms for bait, and, till his secret was discovered, continued to be an easy winner of the Thursday's prize, the boy led on his friend to further anecdotes of birds and fishing. The friar related that when a heron stood still in the water she voluntarily caused oil to ooze from her legs, and, tempting the fish with its taste and odour, was soon able to obtain a meal. Iorwerth, having heard this from the miller, had obtained the legs of a bird struck down by the Earl's fleet-winged peregrine, and, with the help of the Castle cooks, had carefully extracted the oil in a stew-pan.

Renoult fully believed, as many anglers since his day have believed, in the efficiency of heron's oil on baits for trout, and, therefore, that the friar related but a simple fact when he spoke of Iorwerth the monk's success on Thursdays by the fish-ponds. As luck would have it, when the party of merry clerics gained the lower hedge of the abbey garden the boy spied his wild pet, the heron from the nest in the forest, standing apparently asleep in the shallows at the margin of the ponds. He begged the good monks to 


\section{THE HERON OF CASTLE CREEK}

halt awhile, and, motioning the friar to hide with him behind the hawthorms, told, in a quick whisper, how he had often watched the bird in the dell beside the brook, and on her nest in the forest. The friar, who at heart was gentle and a lover of Nature and solitude, listened with interest, and delighted his companion by explaining that the heron always seemed to be asleep when luring fish, and that at the moment she was surely in the act of emitting the oil from her legs to tempt the trout. Immediately the friar had finished speaking the bird, as if she felt something nibbling at her long green shanks, struck downwards and shook her head vigorously, then lifted her beak high into the air, and devoured with utmost relish her glistening prey. Had any doubt as to the friar's explanation of the heron's method existed, it would inevitably at once have vanished, for Renoult was too young and inexperienced to judge that the fish had more than likely mistaken the heron's legs for stems of water weed, and had fearlessly approached them to suck at the glistening airbubbles collected on the scales.

The monks, though they looked askance at the visits of such an expert fisher as a heron to their well-stocked ponds, delighted, scarcely less than to sit fishing in the summer twilight, to gaze from their garden at the movements of a 
swift-winged cast of falcons-the spiral flight, the lofty poise, the sudden swoop on an outdistanced quarry, the trained return to lure and glove. Into their souls, thralled in the service of Mother Church, crept, perchance, a disturbing envy as they viewed the bright train of lords and ladies galloping across the wind-swept marsh; then self-reproached for their own levity, yet longing for the transient vanities of life, they returned from the garden to the cloistered atmosphere of grave-like peace, and at their orisons sought, with the recitation of creed and paternoster, to subdue the desire of the world, and, in duty bounden, prayed that this latest and most searching temptation of the flesh might be cast out.

Directly the monks passed through the garden gate towards the ponds, the heron rose into the air, and, throwing back her stilt-like legs and arching her supple neck, winged slowly off towards the heronry. Thence, as soon as the morning's sport was over, Renoult followed, but he saw neither the old birds nor the fledglings in the nest. So, taking the nearest course through the leafy woods, he climbed to the crest of the dingle, and found the object of his search by the lake below. She was not alone ; following her to and fro in the shallows were three other birds, whose smaller size and unkempt 


\section{THE HERON OF CASTLE CREEK}

appearance indicated that they were the fledglings from the nest in the forest trees. Renoult, not wishing yet to risk discovery, crawled like a snake beneath the gorse, till from behind a shoulder of rock he peeped unseen at the preoccupied family.

The young herons were undoubtedly filled with the importance of their early lessons in obtaining food, and were closely attentive to every motion on the part of their mother. When she advanced, they all advanced, when she trod, they all trod, lifting their long shanks with nervous clumsiness. Generally they moved in single file behind the parent bird, but sometimes, as with excessive caution, she stalked a trout or a minnow that had darted to refuge beneath a pebble in the shallows, or a mouse, or a frog, or a beetle that had hidden in the grass on the bank of the lake, they quietly stole up in line beside her the better to enjoy the sight of good hunting. Hardly had the mother lifted her head after striking her prey, when the young birds, crowding around her, and feebly flapping their wings, begged with low, harsh cries for food. If the catch proved to be an insignificant item in her usual bill of fare, the mother heron swallowed it with ludicrous haste, but if she caught a frog or a trout of any considerable size she at once doubled back among her excited brood, so that 


\section{YOUNG HERONS IN TRAINING 117}

the water she had not already fished might remain undisturbed; then, pretending to find difficulty in eluding their pursuit, she hastened haphazard hither and thither till her most vigorous pursuer forced her to surrender the prize. The excitement having abated, she resumed her stalking, and the members of her awkward squad formed again in line to the rear. The performance was vastly entertaining for the Norman youth; but his cramped position at the edge of the rock became more and more uncomfortable. Presently, turning slightly to seat himself on a grassy knoll, he dislodged a stone, which clattered down from ledge to ledge, rolled across the dingle, and so disturbed the herons that with hoarse cries of alarm they flew off and disappeared over the opposite hill.

Early next morning, Renoult, bent on learning more, again paid a visit to the heron's favourite haunts. From the highest battlement he scanned the creek, but could catch no glimpse of wide blue vanes beating slowly through the clear summer air, or of a lonely watcher by the mud-flats down towards the sea. The entrance to the mill-leat was deserted; the fish-ponds near the abbey were undisturbed save by dimpling trout, and busy coots and waterhens among the lily-pads; and nothing moved along the mere save the pale green flags that bowed and 


\section{THE HERON OF CASTLE CREEK}

nodded as the gentle wind passed by. A squirrel chattered as she explored the empty nest in the forest glade; she showed no signs of fear; its rightful occupants were far from home. Renoult turned away from the glade, and once more wandered up the winding sheep-paths to the hill-top. He looked out over the dingle, but neither by lake nor by brook could he see the heron and her brood.

Tired by his long ramble, he sat on the knoll to rest for a while before making straight across country to the nearest part of the river, that thence, on his homeward journey, he might explore the pools and the reed-beds. Scarcely, however, had he seated himself when far in the direction of the river he saw, just above the blue horizon, the hëron and her young heading straight towards the dingle. So slow was their flight that by the time of their arrival at the lake the boy was comfortably hidden in the shadow of the closest thicket near the rock. Preparatory to her descent by the water's edge, the mother heron, followed by her brood, wheeled several times around the dingle, and once, approaching the rock, almost touched the top of the furze beneath which the boy was hidden. But Renoult lay as motionless as the ground beneath him; and soon the birds, skimming the hillside, vanished below the line of his vision. 
Then, moving forward to the look-out station he had occupied on the previous day, he watched the birds wheeling lower and yet lower till their wings almost trailed the smooth, bright surface of the little lake.

Presently the young herons checked their flight, and, depressing their tails and throwing forward their legs, managed, with much selfsatisfaction, to alight safely at the water's edge, where they began, in the sheer exuberance of their summer mirth, a series of exercises that to Renoult seemed as diverting as the antics of the Justiciar's half-witted fool had been during the recent revels in the Castle hall. Lifting their legs almost to the level of their breasts, they paced awkwardly around a clump of reeds, and along the summit of a grassy mound, where, turning quickly, they bowed to each other with grave formality. Then they marched in single file back to the reeds, and, again turning, lurched from side to side, balancing themselves with half-open wings and occasionally shooting out their long, lean necks as if to guard against a fall. Afterwards, perhaps giddy and out of breath, they for a few moments stood motionless, with their feathers raised around their throats and their heads buried almost out of sight in their distended crops. Anon, recovering from their exertions, they formed a compact little 


\section{THE HERON OF CASTLE CREEK}

group, their heads towards the centre, and each bird standing on one leg only, as the mother heron had sometimes stood in the fish-ponds while Renoult watched her from the abbey garden. At last, breaking away from the group, and strutting, with heads erect and beaks pointing straight upward, around the reed clump and over the mounds, they ended their frolic by a grand parade. Then, returning to the mother bird, they dutifully placed themselves once more beneath her care.

In their sport they had doubtless scared every fish and frog from the neighbourhood of their alighting place, so the old heron led them to the further shore of the lake before beginning the lessons of the afternoon. Evidently determined that her progeny should as soon as possible be able to forage for themselves, she stalked to and fro till her keen eyes detected some small creature moving in the grass ; then she attracted the attention of the young birds by pointing at the ground before her, and allowed them to advance and secure the prize. Each such episode was full of interest, for the fledglings copied faithfully the old bird's movements, and " broke point " only when jealousy and hunger prompted them to a race. Once, in their eagerness, they reached beyond the spot where a half-grown water-vole was hiding, and the little animal, 


\section{YOUNG HERONS IN TRAINING 121}

leaping behind them towards the lake, was killed and eaten by the parent bird.

Out in the shallows of the lake, however, the heron's methods of training were somewhat different. There, though she stalked the trout and the minnows with unfailing patience, she for some time chose herself to catch the fish, which she killed by sharp blows against a stone, and dropped at her feet, that the young might learn how to mark and find their food beneath the surface of the water. Renoult observed that, in comparison with the rest of the brood, one of the herons was small, and weak, and unintelligent. This young bird had been the last to alight by the lake, had taken the least important part in the dances, and had often by its companions been bullied out of the possession of food. But, with all-enduring patience, the mother shielded her weakling, satisfied its hunger with the daintiest scraps that she could find, and never concluded her lesson till her backward pupil had attained proficiency.

The boy's warm, unspoiled heart went out towards the patient mother and the weakling of her brood. Had he carried his long-bow and his favourite arrow he probably would have hazarded a shot at the bullies when they pecked and chased the timorous weakling. Much of what actually happened during the education 


\section{THE HERON OF CASTLE CREEK}

of the young herons was, of course, not known to the watcher; but, had he possessed their keenness of vision, and occupied a hiding-place beside them, he would have learned that the lean, lanky birds, apparently ill-fed, were wonderfully fitted to meet the difficulties of life. Sometimes the old heron waded thigh-deep in the lake, and, seeing a trout or a frog beneath a lily-pad, stole up to the creature without giving it the slightest indication of her approach. Sometimes, either because her presence was detected, or because the over-anxiety of the fledglings to imitate her methods caused alarm, her quarry fled precipitately to refuge among the reeds or beneath the pebbles. Not in the least disconcerted, the heron marked the wake of the fleeing creature, cast ahead and viewed the dim little form shooting down into the depths, then, with the utmost weariness, stalked it again to its newfound hiding-place.

For some time the inexpert fledglings failed entirely in their attempts to learn the secret of their mother's good fortune ; they lifted their feet too high and splashed the water, instead of advancing stealthily and raising their feet only sufficiently to avoid the surface of the pebbly bed. They lacked the old bird's knowledge of the likeliest spot for a basking trout, and they could not follow the movements of their prey 


\section{YOUNG HERONS IN TRAINING 123}

when it hurried from shelter on their approach. Suddenly, however, they gained the trick of success; and henceforth, till the old heron led them back to their forest home, they fished assiduously in the shallows by the margin of the lake.

Often afterwards, when even the weakling became so strong and expert that she would no longer endure the slightest attempts at bullying from the other members of the brood, Renoult, in his rambles over the countryside, watched the family at work or play. And when the hawking season came again, the Earl, much to Renoult's delight, yielded to the intercession of his lady and allowed the rights of sanctuary over the creek, the brook, and the lower reaches of the river, where the lad's wild pets remained for long unmolested. 


\section{A MOORLAND SANCTUARY}

A WINTER night was stealing slowly over a A wilderness of moor and marsh among the hills. A gentle wind had scattered the day-mist and then had given place to a brooding calm. Above a solitary farmhouse on the northern slope of the moor, dark grey clouds had gathered in the sky, while down towards a part of the horizon discernible between a few scattered pine trees sheltering the lonely dwelling, gleamed a thin line of steely light. Towards the west, the outlook changed to the splendour of the afterglow. There, nothing was suggestive, like the white line among the pines, of desolation. The glorious light, spreading across the waste, transformed the withered grass and heather into masses of flame, and was reflected in the reedfringed pools and rivulets among the hollows of the peat. Gradually, the splendour sunk into the west, till nothing but a dazzling yellow bar, against which stood out in relief an ancient burial mound, remained above the horizon.

Then, breaking the silence, a hollow booming cry rang out over the waste, and echoed 


\section{A MOORLAND SANCTUARY}

drearily among the hills. It was the cry of a bittern.

Hidden completely by the lower slopes of the moor from view of the farmstead and the winding road across the hills, was a deep and narrow gorge. At its upper end, a torrent leaped a sheer precipice of rock into a cupshaped pool. Past the shallows at the margin of the pool, the brook flowed between steep banks clothed with fern and heather and strewn with rugged boulders, then gradually broadened, and at the outlet of the gorge was lost amid the tangled vegetation of an almost impassable morass.

From this sanctuary in the wilderness came the loud, weird cry that disturbed the stillness of the gloom. The gorge lay in dense shadow. None of the beauty of the afterglow was mirrored in the pool beneath the waterfall, or in the clouds of spray that wreathed the precipice. But the last golden light from the western sky, slanting across the entrance to the gorge, shone on the lingering vapours above the surface of the brook, and caused them to appear like phantoms rising, one by one, from the narrow mouth of some deep tomb, and gliding away, in long procession, to begin a night's fantastic revels on the marsh.

Suddenly, in the half-transparent haze, the bittern appeared flying from the direction of the 
marsh, and alighted by the stream. For a few moments he paused, as if intently listening, then stalked into the darkness of the gorge. Till midnight the bird continued to search for food beside the brook. But when the moon ascended, and hung like a clear lamp above the waterfall, he stretched his wings, flew up and around the gorge, and up again and further and still further into the heights of the sky; and, uttering a discordant cry, headed south towards a river, followed its course to the estuary, and crossed a headland to another marsh far off on the fringe of the sea.

Spring had come; and the marsh on the coast was the scene of restless activity. By day, the thick reed-beds at high-water mark were thronged with migrant birds on their way to the north and here awaiting the coming of night. During the darkness, the air seemed filled with the noise of beating wings, as flock after flock swept northward. If the night was calm, the noise was faint and continuous, and indicated that the birds were passing high over the marsh ; but when storm prevailed, the sounds seemed to show that the birds were skimming the waves, rising gradually as they neared the land, and then flying a hundred feet or so above the reeds. The bittern's favourite hiding-place was a 
wide hollow, between sand-banks overgrown with rushes and fringed with stunted trees, in the middle of the marsh. There, from dawn to dusk, he slept secure, his long stilt-like legs out of sight in the coarse herbage growing among the rushes, his head turned back beneath his wings, and the delicately mottled feathers of his breast rising and falling as he breathed. And thence, after sunset, he wandered in quest of food, by ditch and bank and across the open waste. And even as he thus wandered he often felt an intense longing to join the ranks of the great bird-armies.

During the previous autumn that desire had been strong within him while the birds were departing from the south; then, however, he was suffering from an injury, and so was unable to venture on the long journey oversea. For he had flown one night far from the gorge to a sheltered valley, where, among woods and cornfields and meadows, the wide river he had recently followed on his way to the sea glistened in the moonlight. The call of the water rippling over the fords could not be resisted, so, descending, he hid among the thickets of a little island in mid-stream. Presently, he emerged from his retreat and stole out into the shadows by the side of the island. He had just begun to fish when suddenly the alarm note of a wild duck to 
her young came from beyond the thickets. This unmistakeable sound was followed by a loud whir as the duck and her brood rose swiftly over the top of the alảers by the bank. Too timid to disregard such signs of danger, the bittern waded back to the island, lowered his head, spread his wings, and launched himself into the air. Instantly he heard an almost deafening noise and felt a stinging pain. Luckily, however, the poacher's gun had not been held quite straight, and the bird, though distressed, was able to continue his flight. With desperate and continuous effort he soared high above the valley, till the wide sweep of the dim moorland, dotted with shining pools and divided by the shining brook, lay before him towards the horizon. On and on he flew, and at last, in the grey light of dawn, reached the gorge once more. For days he languished, stiff and sore from his wound. Fortunately, however, food was easily obtained, and he was free from disturbance; but when at last he recovered, the autumn migration had ended.

It was now the time of the spring migration. Night after night the birds passed over the marsh by the sea; night after night the bittern impatiently longed to depart. Why did he not fly to the near estuary, and thence, by way of the river valley, to his haunts on the moor? The reason 
was that the time for his departure had not fully come; he was waiting. On stormy nights, especially, he was restless and anxious, and listened for the signal that should cause him to journey back towards the hills.

One evening, a cold north-east wind arose, and, as the darkness gathered, a storm of rain and hail beat mercilessly on the marsh. The migrant birds arrived unusually late, and flew so low that they almost touched the tops of the reeds with their wings as they moved slowly in from the edge of the tide, and, slightly altering their course, crossed the wind in the direction of the estuary. At midnight, during a break in the storm, the bittern, standing in the shelter of a rough, reed-grown bank, with his breast to the wind and his head turned sideways to the sea, suddenly recognised, among a small flock of herons and plovers, the familiar shape of a bird of his own kind. His keen sight and hearing could not be deceived ; the form of the approaching bird could be easily distinguished, and its beating wings produced a peculiar sound that could not be mistaken. Rising at once and facing the wind, the bittern uttered a harsh call, which to his delight was quickly answered. His waiting and watching were over; the newcomer was the bird that had shared his last summer's home in the mere beyond the lonely 
gorge. With her he journeyed through the gloom to the estuary, and, again, past villages and farms by the river. As the sun rose, the bittern and his mate circled down, and, alighting on the marsh, rested among the rushes near a broad and shallow channel through which the waters of the brook passed till they were lost among the quaking peat-beds in the bollows of the moor. Fatigued by buffeting against the strong north wind, the birds remained in close hiding during the entire day and the greater part of the following night.

For many years the conditions of migration in the spring had not been more unfavourable; the storm over the marsh by the coast, though apparently not more severe than an ordinary springtide gale, marked the fringe of a terrific cyclone that had swept over Europe and the Atlantic, and driven vast numbers of birds to destruction out at sea. The hen bittern, having wintered in the distant south, was utterly exhausted by the journey, and during the first week after her arrival seldom wandered beyond the marsh; but the cock soon recovered from his weariness, and at night flew restlessly from place to place, as if to make himself familiar with forgotten scenes, and so be better enabled to guard against danger.

Then came the brief season of courtship and 
of preparation for domestic life. How droll were the male bird's antics as, beside the pool in the gorge, or in some spot among the reedy tangles of the marsh, he displayed his charms before the eyes of his admiring companion!. He paced to and fro so proudly that he seemed to tread on air; he swayed and strutted with the rhythmic motion of a dance ; running a little way towards the object of his affections he spread his wings and ruffled the long, loose feathers of his breast; then, turning, he stood still in such a position that the lines of beautiful colouring, not seen before, were clearly displayed to her. Finally, taking to flight, he hovered immediately above her, so that, if all else failed, he might impress her with a show of strength and grace and perfect form.

Spring, on the bleak moor far from the sea, seemed reluctant to make ready for summer. On the hills, at that time of the year, the wind never slept even while, in the neighbouring valleys, an utter calm prevailed. March was bitter and tempestuous; the beginning of April was wet and almost as tempestuous as March. But there were occasional days when, though the wind blew chill and strong, the sun gave life and beauty to the wilderness. On the sheltered slopes of the gorge the heather unfolded its delicate green leaf-buds, and the furze its golden 
blossoms; and the colours of leaf and flower were reflected in the filmy curtain of the falling water, and in the clear, trembling depths around the vortex of the pool, from which fearless little trout, that had never seen an angler's lure, rose gaily to incautious flies. Sometimes an amorous grouse, in all his springtide finery, mounted a knoll on the highest ridge above the heather and the furze, and there, boldly outlined against the sky, stretched his wings, and cackled and crowed, as if he knew and rejoiced that envious eyes beheld him from the gorge. And, sometimes, the great stillness of the moor, of which the unceasing sound of the waterfall seemed a part, was broken by the "drum " of a towering snipe, or the bleat of a wandering jack-hare, or the carol of a joyous lark climbing an invisible stairway to the sky.

April brightened with the progress of spring, and then across the moor came often, mellowed by distance, the faint trill of a hovering plover ; while from end to end of the marsh rang out the loud, flute-like call of a curlew, as the bird, in an ecstasy of delight, dashed to and fro on rapid, whistling wings near the spot he had chosen for his nest.

To the peasant climbing the sheep-path by the farm, these wild voices were almost as eloquent of the freedom of the hills as had been the roar 
of winter tempests. They suggested some great mystery of Nature, but were not in themselves mysterious. Different from them all was the one weird voice that greeted him at dusk, and left with him a thought of immortality.

He would say to the shrivelled figure in the ruddy light of the inglenook, when he tramped into the kitchen after the long day's labour: "Mother, I heard the voice to-night." And the old woman would reply, in the slow, quavering accents of extreme age: "The shepherd is calling to his dog, calling, calling, by the marsh and by the brook. But nothing four-footed ever comes back from the quake. Poor dog! Poor dog !"

The bittern's evening call was considered to be a solemn warning. The peasant observed the utmost care to prevent his dog from straying beyond sight on the outer fringes of the marsh, and himself to avoid, after sundown, the neighbourhood of the dreaded spot. So the rare visitors to the marsh suffered nothing from the dwellers at the hillside farm.

By the end of April, a large nest, carelessly built of reeds and rushes, and containing four pale-brown eggs, occupied a dry tussock of ling and cotton-grass in the heart of the marsh. For some time, every approach to the nest had been vigilantly guarded by the bitterns ; a wild 
duck, crossing a little pool beyond a near clump of reeds, had been compelled to dive repeatedly to escape the bittern's fierce attack, and then, having failed to elude her pursuers in the shallow water, had taken flight in the direction of some more peaceful part of the mere. The curlew, whose home was on the further shore of the pool, dared not wander afoot through the archway of the flags by the edge of the water. For long, each day, he took up his post. as sentinel at some distance from his sitting mate, and piped disconsolately, as if longing to return to his old look-out station-the very tussock on which the bitterns' nest was constructed. Except to scare intruders, the bitterns, however, seldom moved, during the day, from the immediate vicinity of their nest. While the hen brooded and slept, the cock, his head well hidden in the soft plumage of his breast, stood near a clump of reeds on the margin of the pool, and dozed the quiet hours away, or, alert for signs of danger, watched the flight of passing birds. No approaching shadow seemed to escape his notice; the pool before him was a faithful mirror of everything that happened in the sky. Alike in sunshine and in shadow both he and his mate were almost invisible, so perfectly did the colours of their plumage harmonise with those of surrounding objects. 
Summer came, the brief radiant summer of the open upland moor, when the days are torrid and the nights are cooled by a gentle breeze, and the few bird-voices of spring are hushed. Its approach was not indicated by the sudden unfolding of the leaf-buds on the trees; the only trees on the moor were the pines near the farm, and they were always green; the grass, except immediately around the marsh, was stunted and parched by the fierce heats of noon. But along the hills the colour of the heather had slowly deepened on the lengthening sprays, and the bracken had thrust up its branching fronds till every trackway of the grouse and the hare resembled a bowered lane through which the creatures could wander unseen. And on the marsh the reeds and flags were tall and thick, and waved to the breath of the wind. Regularly now, in the twilight, the bitterns, leading a little family of three grey-brown birds, stole out from the mere to the brook, and thence to the gorge below the waterfall. Frogs and slugs were plentiful in the undergrowth when it was wet with dew, and, occasionally, a trout, in the act of leaving the pool to feed down-stream, could be surprised among the pebbles where the water narrowed near the side-channel of a neglected sheep-pond long since overgrown with weeds. The gorge was a chosen school, in which, safe 
from all enemies, the young bitterns could be taught to exercise their wings and seek for food, in preparation for a later life of separation from the parent birds.

The heat of summer waned with the advent of August. The purple of the heather rivalled in beauty the deep orange that had taken the place of a lighter yellow in the earlier blossoms of the gorse; and at sunrise, when the bitterns flew home to their sanctuary in the marsh, the pale blue of the rolling mist, and the first golden rays of the sun, blending with the colours of the flowers, transformed the wilderness into a paradise whose splendours surpassed even those of the afterglow of the previous winter, when the male bird was about to depart to the coast.

Then, with tragic suddenness, the sanctuary of the mere was violated, and its peace disturbed. Early one morning, before the moon had set, and while the bitterns as usual were feeding in the gorge, an old, unmated fox, that for years had haunted the lonely countryside, trotted leisurely down the sheep-path past the farmstead, and across the rough hillside, to drink at the brook. $\mathrm{He}$ discovered, as he stooped by the water's edge, that the scent of a young hare was fresh on the sodden grass, but, as he followed the line for some distance by the only safe track-way through the marsh, it became faint and was lost 


\section{A MOORLAND SANCTUARY}

among the reeds. The fox's home was in a cairn not far from the highest point of the moor; but, since the air was warm and gave promise of a perfect day, he turned aside from his path, lay down on the dry tussock where the bitterns had nested, and fell asleep.

At dawn he was awakened by a faint rustle among the reeds. Peeping from his "seat" he saw the bitterns slowly approaching him along the track-way by which he himself had come in pursuit of the hare. His eyes ablaze, he crouched for an instant; then, bounding from the tussock, he struck down one of the young birds and fastened his teeth in its breast. The other young birds quickly vanished, but, as the fox stood over his fluttering victim, the parent bitterns, abandoning every thought of danger, closed in and struck him repeatedly with their beaks and wings, inflicting such strong and rapid blows as for some moments to bewilder their enemy. He retreated a few paces; then, recovering from his confusion, and mad with rage, he leaped high into the air-once, twice, thrice. The conflict was over, and before him lay, fluttering in the throes of death, the two rare and beautiful birds which, probably alone of all their kind, had nested that year in Britain.

Away on the fringe of the marsh, the fugitive young bitterns lurked in hiding through the day. 
At evenfall, they began a weary search for their missing parents; and often, through the night, their weird calls resounded in the wilderness. But the only answer that came was an occasional echo from among the slopes of the gloomy gorge. And among the boulders of the cairn on the hill-top, the old fox, vainly endeavouring to pass the time away in sleep, moaned and writhed with pain. One of his eyes had been torn from its socket in his brief battle with the birds. 


\section{THE PARTRIDGE}

\section{I}

Partridge Nesting Habits

TTWM SÂR was the genius of the hamlet.

1 His neighbours relied on him for help in doubt and trouble. His little "shop" stood at a corner of the cross-roads; and almost filling it from door to window was a collection of old furniture, boards, planks, carpenter's tools, clogsoles, boot-lasts, nails, screws, rusty bicycle wheels, paint-pots, brushes, soldering irons, picture frames, block-pulleys, cart-shafts-all sorts and conditions of things likely to bewilder a chance passer-by who might desire to know what Twm could do or what he could not do. Amid this litter, an apprentice boy might at odd hours of the day have been seen at work; but Twm was seldom found at home. Either he was away at some lone farm among the hills, building outhouses, mending clocks and chairs and implements, doctoring cows and sheep, assisting at seed-time or harvest ; or he was out among the three-acre fields of his own little 
freehold, engaged in one or another of the tasks he there found ready to his hand.

Though clever at most things, Twm was not a good farmer. The pastures near his farmhouse-that nestled among the trees at the end of the lane beyond his "shop"-were overgrown with weeds; the hedges even of his cornfields were thickets of furze and brambles, with here and there a sapling oak or ash, and the gates were mere hurdles of split larch plaited with branches of hazel and alder. Twm Sâr's most cherished possession was a breech-loading gun of an obsolete French pattern that hung in the roof-tree of the kitchen at the farm. The old man had once been a poacher, inasmuch as he had shot game without a licence. But later, while he preserved his land with jealous care as had been his custom in the past, and each autumn fondly hoped for a few hours of leisure in pursuit of game, Twm never took his gun from the roof-tree except to scare the crows from the corn, or a prowling fox from the hencoops in the yard. It was a kind of fad, or hobby, with Twm Sâr that, till the bright autumn morning when his work might be laid aside, wild creatures such as had given him sport in his youth should find on his farm safe sanctuary from human foes. But when that autumn morning dawned, Twm was too feeble to go into the fields. 
A mild afternoon in March was merging into dusk as the old farmer-carpenter closed the gate of his cornfield, and, guiding his plough over the ruts and the stones of a rough pathway behind the farm, trudged homewards with a weary team. The clank of harness and ploughshare had died away, leaving the silence of the plough-land unbroken except for the cawing of the rooks, when a partridge suddenly appeared from a rabbit-creep and wandered over the newcut furrows in the cornfield. The little brown bird, alert for every sign of danger, moved out into the fringe of grass between the nearest furrows and the ditch, and for a few moments fed daintily on some fresh sprouts of herbage exposed by the plough, and on grubs and flies that, disturbed from their winter sleep, were hurrying over the damp clods to seek the shelter of the grass.

Instinctively feeling the presence of springin the scent of the earth, of the grass, and of the buds on the gorse by the ditch-the partridge stood upright, while the westering light shone full on the horse-shoe markings of his breast, and uttered his cry, ke-whit! ke-whit! ke-whit! And what an unexpected noise he made! This was the first time he had attempted the "challenge," and for a moment he was almost startled by his own effort. A rook stalking over a near 
ridge was so surprised that he jumped aside and flew to join his sable companions in a far corner of the plough-land; a field-vole under a withered bramble scurried to his burrow in the moss; a rabbit in a clover patch beyond the hedge sat up on his haunches to listen, drummed his alarm, and hopped into the shadowy thicket. For the voice of the young partridge was as unlike the full clear voice of an older bird as the first crow of a barnyard cockerel is unlike the long-drawn challenge of an experienced rooster ; and the rook, the vole, and the rabbit were suspicious of its meaning.

Then the partridge, remembering how the arrival of the farmer in the morning had caused him to hide for safety in the furze while the plump little hen bird to which he had begun to pay court hastily returned in the direction whence she had come soon after dawn, flew leisurely over the hedge and across the adjoining pasture where the rabbits were frolicking in the clover patches around stray tufts of withered grass. As he flew the partridge sought everywhere for signs of the presence of his kindred. His search for a while seemed vain, and he was in the act of alighting beside one of the grass tufts, when his keen eye detected a dim round form stuanding some distance away on a knoll among the rabbits. Half running, half flying, and, now 
that the desire of spring was strong within his quick-beating heart, equally ready for love or battle, he reached the knoll and surprised his companion of the morning as she was about to enter the tangle of the grass.

At first she paid slight heed to his gentle purring notes of affection, and treated his advances with cold disdain. Every note and movement of the birds seemed eloquent. "I have found you at last, at last, little love," he said. And she, with indignant gesture, made answer, "Who are you, who are you, seeking me at suppertime in the twilight of the grass?" "Pretty brown bird," he continued, "don't you know me? Don't you see the bright russet horseshoe on my breast? Don't you remember that I met you in the furze-brake after sunrise, and we were together for hours till the ploughman came and frightened us into hiding from the stubble?" And plainly she rejoined, "Go away, go away ; I do not choose to call to mind what happened this morning." Nearer and still nearer her suitor approached. In pretended fright she abandoned her haughty manner and ran to the far side of the knoll, but before she could look around he was at her side. Again and again she attempted to escape, only to discover, however, that her persistent admirer could with ease out-distance her. Secretly admiring his 


\section{THE PARTRIDGE}

grace and strength she at last admitted his conquest. Later, the wan moonbeams shining through the mist of night lingered on the two little wildlings crouching together, head under wing, asleep on the narrow path that Twm had left unploughed between the furrows in the middle of the cornfield.

A few weeks of early springtide weather were succeeded by gloom, and tempest, and bitter frosts; winter unexpectedly returned to mar the work of the husbandman and blight the hopes of the hedgerow songsters busy with their nests. Following the custom of their kind the partridge and his mate became members of a "pack" that, under the guidance of an old and experienced bird, frequented the southern slope of a hill beyond the hamlet. In the pack were half a dozen mated couples, and among the males fighting was frequent; but when the cold weather passed away, and the pack broke up, the relationship of each bird to its partner seemed to have remained unchanged. The young partridge from the plough-land in the valley returned with his mate to his winter haunts; and presently, when the hen bird had grown familiar with her new surroundings, the little pair searched the hedgerow thickets for a nesting place.

The sparkling crystals of a late white frost 
had vanished from the grass. The ash trees and the oaks unfolded their pale green and olive leaves; their lowest branches drooped over the matted thickets of the ditch. Clusters of celandine peeped from every bank, with violets and hyacinths, anemones and primroses. The pale-golden broom, the ruddygolden gorse, their splendour two-fold in the golden sunlight, seemed to make a garden's paradise of the roughly cultivated fields about the dwelling of the hamlet carpenter. Beside an oak in the lower hedge of the cornfield and behind a screen of broom and furze, yet away from the beaten track of rabbit and vole, the partridges had built their nest. Hardly perhaps could the few bent and withered leaves collected in a slight depression of the soil be called a nest. Yet nothing more was needed. Sheltered from wind and rain in such a position that even the drops of a summer shower would not fall into the hollow from the tree overhead, and hidden from the keen sight of sparrow-hawk and kestrel, the nest suited its purpose admirably.

By the end of May a dozen glossy brown eggs were deposited therein, and over these the hen bird brooded tenderly, sitting closely hour after hour, and leaving her charge only at infrequent intervals for food and recreation. The fussy long-tailed titmouse, that had her lichen-covered 
home in the furze-brake a few yards away, was scarcely more attentive to her domestic duties. And awhile the petals of the broom and the gorse fell in a scented shower on the grass, the hyacinths and the violets were succeeded by the may-bloom on low hawthorn sprays beneath the oak, and in the undrained pasture beyond the hedge the jewelled cups of the marsh marigolds fringed a tiny pool where the birds of the neighbourhood were wont to drink and bathe.

Whenever the hen partridge rose from her nest she covered the eggs with leaves and grass, so that if in her absence sly carrion crows or hunting weasels happened to peep through the hedgerow the treasures in the hollow should remain unseen. Even the most harmless of Nature's wildlings are at all times keenly inquisitive. Knowledge of animal life is often obtained only through familiarity with creatures whose intelligence has been blunted by domestication, and we are accustomed to imagine that the denizens of our woods and fields take at best a perfunctory interest in their surroundings. From watching a cow feeding in a pasture we can form but few ideas of the habits of her kind in remote ages, when they lived in herds amid the dense growth of scattered forests and marshy plains, and were surrounded by powerful enemies. Those unapproachable wild geese that, in the 
rigid winter, occasionally visit the up-country lake, and tempt us to feats of cunning and endurance comparable with those of an Eskimo watching a seal-hole in a floe-can they in any way be likened to the waddling flocks that supply our Christmas table with its choicest viand? The man who attempts to read wild Nature's book and is familiar only with the lives of domesticated animals is much in the same position as he who, having merely learned the Greek alphabet, essays forthwith the translation of Homer.

The creatures of wood and field may be divided into two classes - the hunters and the hunted. The business of the hunters is to learn the ways of the hunted, and so with ease obtain their food; while that of the hunted is to learn how to escape destruction. Sometimes, like the squirrel that, while raiding a blackbird's nest, is pounced on by a sparrowhawk, or a weasel that, while hunting a vole, is killed by a fox, the hunters become themselves the hunted. Whatsoever may be their path through life, wild creatures are continually alert as they travel therein. From each experience by the way they gather a little. Should something strange meet the eye it is approached cautiously and examined carefully, that in future it may be avoided, or pursued, or treated with indifference. 
This inquisitiveness affords the naturalist delightful studies of character in wild creatures. As might readily be supposed, curiosity often leads to mischief. The partridge, when on leaving her nest she covered it with leaves and grass, safeguarded her treasures from many dangers. How might the safety of the eggs have been affected if the nest were uncovered and a red bank-vole-an innocent animal, indeed, compared with the weasel or the stoat-passed by ? It is more than probable that the vole, his curiosity awakened by the unusual sight of a clutch of glossy brown eggs, would disarrange them, either from sheer love of mischief, or because he smelt some fresh, sweet stalks of herbage which under the warmth of the hen partridge's body had sprouted among the eggs, and desired at all costs to obtain the tit-bit. The vole would not trouble about the safety of the eggs as he searched for the young sprouts beneath the nest. The desertion of their home by the disappointed partridges would be well-nigh inevitable after such a visit from the vole.

From an incident I witnessed in the life of Bright-eye, the water-vole, I might write, perhaps, another story of disaster to an uncovered partridge's nest. Late one evening in spring I was lying in the long grass on the river-bank. A few yards from my hiding-place, out on a 
willow bough over the pool, was a moorhen's nest containing six downy chicks and an addled egg. For an hour I had watched the parent birds tending their young and swimming and diving into the pool. Darkness was drawing on when I heard the clatter of a loose pebble on the shelving bank immediately below the willow root, and, a moment afterwards, saw the watervole creeping along the overhanging trunk towards the moorhen's nest. As the vole neared the outer branches a low gurgling call-note came from one of the parent birds, and instantly each of the chicks dropped over the rim of the nest and disappeared. The vole reached the nest, and, without hesitation, dived into the pool beyond. Again I heard a slight sound on the gravel below the bank; then a full-grown otter came into view, stood erect and sniffed at the willow-trunk, climbed to the branch, and followed on the scent of the vole. On the edge of the nest the otter paused, moved from side to side as if intent on a close examination of the spot, slipped into the water, and glided from view just as the vole floated up to the surface of the water in the shallows near the opposite bank. Soon the pool around the moorhen's nest was apparently the scene of a tragedy. The old moorhens swam along by the reeds at the margin, and hither and thither past the willow bough, calling plaintively 
and trailing their wings as if in great distress and pain. The hubbub continued, but the night was too dark for any further observation of their movements. Next day when I visited the spot, only two little fledglings squatted on the platform of rushes at the end of the willow bough, and I judged that the water-vole, while fleeing for his life, had thrown the otter off his scent, and that the moorhen's brood had been hunted instead.

Something similar might have happened had the partridge left her nest uncovered. The bank-vole, even if he himself did not destroy the eggs, might, in all likelihood, have brought about their destruction by another creature. Chased by a weasel, he would, perhaps, have led his pursuer over the nest, with the result that, while he himself escaped, the "vear" would stay and greedily devour the unexpected spoils. The hare and the fox show great cleverness in their attempts to baffle the hounds. While running through a flock of sheep, their only object may not be ta delay the hounds by "fouling" the scent. Probably, what they most desire is that the hounds should recognise the presence of other animals that may well repay persistent hunting, and should thus forget the object of their first long chase. Of course, the fox and the hare cannot take into account 


\section{PARTRIDGE NESTING HABITS 151}

the human intelligence directing the hunt. In long past ages, when the wild ancestors of the modern foxhound coursed the hills and the plains, that intelligence was lacking, and the artifice was always likely to succeed. Now, among the smaller folk whose conditions are much the same as they have ever been, the ruse is practised as one of the principal means for the preservation of life. 


\section{THE PARTRIDGE}

II

The Summer Life of the Partridge

TT was June, and Nature stood on the thresh1 old of summer. The crab-apple bloom had fallen; the earliest dandelion seeds had drifted away. The swifts, from their nests under the eaves of the farmstead, flew wheeling and screaming high in the trackless sky. Out beyond the furze-clad hedgerow, the young wheat grew rapidly, hiding with its rich greenery the expanse of brown plough-land. Already the mothering hare had worn a trackway between the stalks from her "form" on a neighbouring bank to the gateway by the lane; and the finches and the yellowhammers often led their fledglings thither to a sanctuary where, under the arching verdure, they were safe from hawk and weasel as they wandered to and fro in search of food. The day wore peacefully away, and the hen partridge, brooding over her eggs on the nest by the ditch, closed her eyes to the bright sunlight and fell asleep. She was awakened by a faint 
noise of scratching and pecking beneath the feathers of her breast, and her little heart fluttered with joy, as, with head held downward and aside that she might catch each repetition of the sound, she listened intently. Soon the scratching and pecking could be heard from other parts of the nest, and, near her feet, she feli that an egg was broken, and that a tiny chick was feebly moving towards the edge of the nest. The brooding partridge lifted herself gently, till the chick, with a twitter of contentment, gained the warm, well-ventilated shelter of her wing.

Now, instead of resuming the position she had previously occupied, she held herself slightly higher above the nest, that the air might pass freely between her body and the eggs. At intervals, for some hours, the sounds of chipping and twittering were continued; and before evening all but three of the eggs were safely hatched. The mother bird succeeded in cracking one of these three eggs, and thus releasing a chick that had vainly striven to break the shell; in another, a weakling died after vain attempts to secure its freedom; while the third, in which could be detected no sign of life, was allowed to remain for a time among the chicks, and ultimately, when the mother bird put her home in order, was removed to a place amid the rotting herbage of the ditch. 
Darkness fell over the countryside, and as long as it lasted the partridge chicks did not venture from their nest. But with the first peep of dawn, little heads were pushed from between the yielding feathers of the mother's breast and wings, shining eyes looked forth on the beautiful new world of summer, and low twitters of curiosity and wonder were exchanged. Soon, joined by her mate, that had slept in a grasstuft by the nest, the hen-bird led her brood through the "creeps" of the rabbit and the hare into the growing corn, where, running to and fro, and gossiping intermittently of their joy and surprise, they fed on seeds and insects pecked from the soil or from the dewy herbage about the stalks of the wheat, while the parents guided their movements with scarcely audible notes of warning or encouragement. They soon grew tired; and, when the sun rose over the tallest tree by the gateway, they nestled again beneath the hen-bird's wings as she crouched on the nest, and the cock, standing in the shadow of a clump of thistles close beside them, kept watch for every sign of danger.

At noon the little family adjourned to the hedge-bank, and there, choosing a dry, sunny spot by a rabbit burrow, the old birds indulged in a luxurious dust-bath, fluffing out their breasts, idly stretching their wings and feet, and kicking 
up the loose loam over their plumage, while the chicks, curious and surprised as when they partook of the morning's meal, attempted, with comically feeble gestures, to share in the performance of which as yet they could not understand the meaning. The afternoon was spent in wandering through the corn and along by the tangled hedge behind the nest, and the evening in feeding and playing among the cool shadows of the root field.

For several days the brood remained in the near neighbourhood of the nest. The mother bird still hoped for an increase in the number of her chicks ; but one morning, having recognised that her hopes were vain, and having removed the two unhatched eggs, she led the young away, and nevermore returned with them to sleep in the shelter of the gorse. Had they continued to frequent cover, the young birds, unable to fly, and leaving behind them a strong, widely diffused and easily followed scent, would, sooner or later, have been attacked by prowling stoats or weasels. During the rest of the summer they generally slept in some place among the open fields, where the dew-fall was not so heavy as on the dense verdure of the meadow grass and the corn. The mother partridge, her duties sometimes shared by her mate-whose solicitude was almost equal to her own-nightly took her chicks to the 
shelter of her wings, till they had grown too big to nestle in comfort there ; afterwards, as darkness deepened, the covey "jugged" together, forming a ring, with heads turned outwards, that no danger might steal on them unobserved.

The old birds at all times took the utmost care that other coveys should not trespass on their haunts. Once, when a pair that had nested in a fallow beyond the carpenter's farmhouse ventured into the wheat, a desperate fight occurred, and the intruders were routed and driven back to their own domain. The partridges jealously sought to ensure that their provender should not be shared, and also that foes should not be attracted to their neighbourhood. The finches and the yellowhammers, searching for seeds dropped in the grass, were often forced to fly for safety to the trees; and the skylarks, about to tuck their heads beneath their wings for the night, were likely to be unceremoniously evicted if the "brown birds" chose to roost near by. Fearing none but birds and beasts of prey, the old partridges would, without hesitation, attack a pigeon or even a pheasant that chanced to cross their path.

Towards noon one day in mid-July, when the dew had dried on the undergrowth and the creatures of field and hedgerow seemed to be at rest after the morning's work, the partridges 
were lazily " dusting" on a mole-heap in the hayfield. Not far off, the hare with her two leverets squatted in their runway through the grass, and the rabbits basked in the warmth on the outskirts of a thicket between a patch of clover and the hedgerow. Suddenly the cock partridge heard the distant clank of chains, the hoof beats of a horse, and the shout of a man. The sounds reminded him of the day in early spring when, concealed in the ditch, he had watched the farmer ploughing the cornfield, and the little hen partridge had stolen back from the furzebrake to the fields in which she had been reared. Uttering a low "cluck, cluck" of warning to his brood, he quickly ran with them to closer hiding in a dense thicket of the grass.

The sounds drew nearer, the gate swung open, and, after an interval of silence, a rattling noise, mingled with the measured thud, thud of the horse's feet, passed down a path by the hedge that the farmer on the previous day had cleared with scythe and hook. All through the afternoon the loud, monotonous rattle continued, now on one side of the field, again on the other, while the patient horse plodded on and on, and the cut grass fell over in even swathes as the mower gradually approached the middle of the meadow. Bewildered, and not daring yet to cross the widening gap beyond the unmown 
grass, the rabbits and the hares moved hither and thither; and the partridges, their alarm increased as they observed the signs of general panic and were hustled by their neighbours, often made rash efforts to escape, but were as often deterred by the confusing noise about them. At last, when from any point in the undergrowth the movements of the mower could be clearly seen along the swathe, the hare and her leverets limped off towards the hedge, and the rabbits scattered and fled at utmost speed to their burrows. Terror-stricken, the partridge brood ran out and crouched at the edge of the grass, hoping that there they would escape the impending danger. In the nick of time the farmer, bending over the side of the mowing machine, caught sight of a shining eye, and stopped his horse. Hastening into the tall grass behind the covey, he waved his arms and shouted loudly; then, as the old partridges flew out and alighted on the swathes a few yards distant, and the young birds, with drooping wings, scuttled away to join their parents, he muttered, in his deliberate, self-convincing manner, "If I'm not too busy when September comes, that ot o' birds'll give some fun. Maybe I'll get the loan of a setter in the village; but if I don't, the gen'leman at the big house'll be sure to let me shoot over his slow old spaniel for a day." 
But, as usual, Twm, the farmer-carpenter, did not mature his plans.

Though by night the partridges, their habits acquired from the experiences of many generations of their kindred, never slept in thick cover, by day they frequently wandered through the ditches, the outskirts of the furze-brakes, and the thick verdure of the cultivated land; for then they feared, not the stoats and the weasels, but the crows and the hawks, and were safer amid the brambles and the gorse, and even in the long grass and the standing corn, than in a bare pasture or a new-mown meadow. Their own particular domain-beyond which they seldom ventured, save to explore its surroundings, and thus to learn of a possible refuge should they be evicted from their haunts-consisted of the meadow, two rough pastures partly overgrown with " trash," the cornfield bounded by the hedge in which was their deserted nest, and a small field of "roots" and barley. One of their favourite resorts had been the meadow, and for a while they still visited it at dawn and dusk to pick up seeds and grubs.

The gateway from the meadow to the pastures had not been closed since the laden wagons passed homewards from the harvest; and through the opening the cattle sometimes strayed. Early one morning, as the partridges were feeding 
near the spot where the farmer had saved them from the teeth of his mowing machine, an old ill-tempered cow, fancying they were trespassers, gave determined chase. In the pastures they had already grown accustomed to her bullying tricks, and so, easily avoiding her clumsy pursuit, they scattered and ran off full speed towards the gateway. Suddenly the cock bird, seizing the opportunity of inducing his brood to use their wings, rose into the air, and they, squeaking with excitement and misgiving, flew up and hurried after him. Only two or three times previously had the chicks succeeded in making short flights from field to field, and not as yet had they learned the importance of rising together in quick obedience to the signal of one or other of their parents. The meadow sloped rather abruptly to the hedge; this circumstance favoured their inexpert movements; so they sped on in an irregular line, followed, as soon as they were well on their way, by their mother. They had reached the gateway, and were about to turn across the hedge into the wheat, when. a sparrow-hawk shot with lightning swiftness along by the hawthorns, and struck down the two last weaklings to the earth. The mother partridge saw the hawk descend to complete his cruel task, swerved through the bushes, and dropped like a stone into the ditch on the far 


\section{SUMMER LIFE OF THE PARTRIDGE 161}

side of the hedgerow. There she lay, her little heart beating wildly, till at twilight, anxious for the safety of those of her young that had escaped the hawk, she summoned courage to wander on to where they fed by a tiny rill at the margin of the root-crop. 


\section{THE PARTRIDGE}

\section{III}

\section{Enemies of the Partridge}

TN the old-fashioned hedges of Twm the 1 Carpenter's farm, and in the adjoining furzebrakes and bramble clumps, the rabbits, as they fed and gambolled at dawn or dusk, could remain unseen from the open fields. Lurking in and near thick cover, they acted as if birds of prey were their most dreaded enemies. The days of falcon and eagle, however, had long passed, and the worst foes that now remained to harass the weaklings of the hedgerow thickets were the members of the weasel tribe. The rabbits were seldom safe from these bloodthirsty little pursuers. As summer drew on, the weasels and the stoats, hunting in family packs, wrought such havoc that, had not the power of reproduction among the rabbits been extraordinary-as it always is among defenceless creatures, the history of whose lives is mainly a record of hair-breadth escapes from death-the thickets must have been depopulated.

Despite the daily, almost hourly, slaughter, 
no decrease was noticeable in the number of the rabbits; always the signs of their "traffic" on the mounds near the burrows seemed to be fresh; and, in the moonlight, when fear of dog and hawk was forgotten, they moved hither and thither by the margin of the tangles, and, venturing even into the middle of the field near the roosting-place of the partridges, fed and played without a thought of death. Sometimes a hunted rabbit escaped by leading her enemies in and out of the tortuous trails through the undergrowth, where, at every step, the scent of other conies crossed her own and baffled close pursuit.

In the early morning and late afternoon these cross-scents were so strong and numerous that the partridges, while wandering between the outer line of the furze-brakes and the hedges, seemed to be surrounded by a different atmosphere from that of the open fields, and their movements rarely excited the curiosity of the weasels or the stoats, unless the animals chanced to arrive at a spot where the brood had lately "dusted" in the dry loam near a gap, and where the scent of the birds' bodiesfar more powerful than the scent of their claws and legs-could be readily distinguished from anything indicating the presence of the rabbits. In a small but dense covert on the hillside, 
to which, during the previous winter, the old partridges had resorted when they "packed," a vixen, with a family of cubs that were now rapidly learning how to obtain their food without her assistance, lived in a carefully hidden "breeding earth" beneath the roots of an oak. Nightly, the rovers stole through the gloomy woods and through the narrow belts of shadow cast by the hedge-banks over the dewy fields, and their quick yet careful methods of hunting were disastrous to the voles and the rabbits surprised in their journeys.

The hare, who had made her springtide home near the wheat-field, now dwelt in a dry "form " among the reeds in the lower pasture. Her "run," however, still led through the cornfield to the gate; thence, after ambling down the lane, she generally made off to the hillside, and skirted the fallows above the wood.

The vixen and her family had discovered her whereabouts, and on several occasions had vainly endeavoured to capture her while she fed in the clover away from home. One night, on the margin of the root-crop, they followed the line of her scent, and attempted to surround her as she lay in a clump of grass. But in the nick of time she bounded from her "seat," swerved, and thus eluded one of the cubs which made an effort to close in on her; 
then she darted through the gap, and with long, easy strides hastened across the pasture towards the wheat. For a moment, the fox-cub stood bewildered; then, realising the situation, he cleared the gap, and, keenly excited by the prospect of a chase, dashed after the fleeing creature. Breathless from his impetuous rush, he halted in the middle of the pasture, and was about to return in a direct course to the hedge when, suddenly, almost beneath his fore-feet, he smelt the sleeping partridges. With light footfall, he turned for an instant, to make sure that his senses had ot been deceived; but as he moved the slight rackle of a withered leaf awoke the covey, and, with a low twitter of alarm, the cock-bird, followed closely by his mate and all but one of the young partridges, flew up in the darkness. As the hesitating "cheeper" ran forward to gather momentum for flight, the fox leaped swiftly, and with a. single blow struck it to the earth.

Confused by the sudden disturbance of the young fox, the survivors of the covey separated from one another; but, helped by the gentle breeze of the summer night to direct their course, they all eventually reached the rootcrop, and, still scattered, sought refuge here and there among the turnips and the potatoes, and in the barley that grew at the lower end 
of the field. Wandering afoot between the dewy stalks and leaves, and listening to the frequent call-notes of the cock, they succeeded in reuniting in an open space between the barley and the roots, then settled, once more, to rest. But their fright had filled them with misgiving, and the faintest sound of a windstirred leaf roused them at once from slumber. With the first peep of dawn, they moved away, cautiously and silently, and sought a well-known sanctuary where, hitherto, they had never been disturbed.

It may often be observed that partridges, when they take flight without the least suspicion of danger, but simply to exercise their wings, or change their feeding quarters, do not rise straight or far from the ground. The signal to rise is given in a low, twittering note by the old partridge that leads the way. As on such occasions the parent birds fly along routes familiar to their offspring, and do not wander to any considerable distance, the youngsters need not hurry their departure. They sometimes wait till they have finished a light meal; then, thinking perhaps that their parents have had sufficient time to find for them a further supply of food, they leisurely make off in the direction taken by the cock; and soon the covey is once more complete. 
Frequently, instead of rising over a hedge, and thus risking a surprise attack from a quick winged bird of prey, they steal through the ditch and between the hawthorns before venturing to use their wings. Another circumstance may be marked: the whirring noise of wingbeats is not so loud when the cock partridge takes to flight of his own free will as when he is alarmed. It is, of course, only natural that a bird, when forced to ascend hurriedly from the ground, should make a greater commotion than when haste is unnecessary. The wing-beats have a language; each pitch of sound indicates precisely some condition of alarm or contentment, and its meaning is immediately known to the members of the covey, and probably to every other beast or bird within hearing.

Partridges in hilly districts hereabouts show decided fondness for nesting on a slope that faces the morning sun, or on a plateau where the sun shines continuously from dawn to dusk. Such a place is generally dry and well sheltered. It has also this advantage : in winter, when the prevalent breeze blows from the high ground above or behind this southern slope, the birds can quickly escape from danger approaching them down-wind. If alarmed, they rise against the breeze, so that the air current, however slight, catches their slanted wings and assists 
them from the ground. They then turn, and, with the slope before them and the full force of the wind behind, fly at high speed, and with little noise and exertion, down into the valley, where, utilising the momentum gained in their descent, they wheel, and thus baffle any pursuer following the first evident direction of their flight and hoping to find them again by a forward " cast." Sportsmen out shooting on the winter stubbles are nonplussed time after time by this simple expedient, and, failing to observe the turn of the partridges' flight, hasten to the bottom of the valley. Afterwards, keenly expectant, they search each likely place along the lower part of the hill; but, meanwhile, the birds, having rested there for an hour or so, return to the fields where they were flushed.

When abroad on the hills in the wet winter weather I have repeatedly found partridges on the east side of hedges in bare spots beyond the drift of the trees, and yet sufficiently near to the bank to be screened from the driving showers. They have hurried for a considerable distance through the ditch directly the setter, facing them against the wind, came to point, and, drawing the dog slowly after them and out of the dangerous position he at first occupied, have taken flight, when the way was clear, to the valley. When surprised at night, part- 
ridges face the wind immediately, and rise almost vertically into the air. Expert poachers, aware of this habit, work against the wind, and hold their sweep-nets in such a position that while the lower meshes trail along the ground, the upper meshes, to intercept the frightened birds, can be instantly thrust forward and " clapped." If, under ordinary circumstances, forced to leave their roosting-places, partridges on a dark night rise to a greater height than by day.

I have noticed that, when they have thus ascended in the dark, it is well-nigh impossible to judge of the direction in which they turn; their movements become strangely silent, as if, with slow flight, they were endeavouring to ascertain their whereabouts and guard against the dangers of the gloom. Occasionally the young birds utter soft, musical notes; but these are strangely illusive to the human ear, much as are the harsh calls of the corncrake in the summer grass.

The partridges were accustomed to the noise and the activity which by day were inseparable from the ordinary life of the summer fields. Intelligent and high-spirited, they were not daunted by what they usually saw and heard as their neighbours wandered near in search of food. Straying among the sheep and the cattle that drowsed in the shade of the hedge- 
banks, or under the great oak trees by the lane, they even ventured to peck at the insects their sharp eyes detected alighting on the flanks of the recumbent animals. But during the twilight they loved to frequent sequestered spots not far from chosen sleeping-places, and in peace to feed and prepare for the night. While thus engaged, each foraging apart, but within easy distance of the parent birds, the chicks were keenly attentive to every occurrence in their immediate neighbourhood, and, as at night, were extremely liable to panic and its attendant longcontinued distress.

A sportsman whose "preserve" is small, and who shoots partridges over dogs, knows well that if the disappointment of a blank day is to be avoided the birds must be left unmolested in the early morning and the late afternoon. Nothing more certainly causes partridges to become unapproachable, and finally migrate to distant farms, than the habit which inexperienced men possess in beginning their sport soon after dawn and relinquishing it only when dusk veils the countryside.

Years ago, circumstances illustrating forcibly the truth of this came under my notice. Through the courtesy of a farmer owning and living on a small freehold, I was allowed to ramble with dog and gun about a sunny hillside overlooking his 
home. The old man was a true naturalist, in every sense of the word; and the days I spent with him "looking for 'oodcock" were among the happiest of my life. Every field on the hillside was in full view from the farmstead, and poachers, aware that their presence would be unwelcome, rarely, if ever, crossed the thick boundary hedge at the brow of the slope, except on a fair-day, when they believed that the farmer would be from home, or on Boxing Day, when by immemorial custom everybody who owns a gun may "blaze away" to his heart's delight on any farm whither his fancy leads him, and, moreover, may claim the hospitality of the festive board when he tires of his fun.

On the farm, or, rather, on the particular hillside I have mentioned, partridges were always to be found in fair number during the season, till the young paired off and sought homes elsewhere. I shot also over the lands between our village and the farm, and, early in the season, could obtain sport on my way to see my old friend. But those lands were also frequented by men whose favourite evening recreation was to take a stroll with gun and spaniel. No very deadly marksman was among the members of the party, but all were expert in ascertaining the direction of a part- 
ridge's call-note, in creeping about the hedgerows, and in "spotting" the exact position occupied by a covey that had collected to " jug "; and all could shoot with some degree of certainty at a motionless bird on the ground. Till I knew that these fine sportsmen shared my privilege, I wondered greatly why on the uplands between the village and the farm the habits of the coveys changed suddenly after mid-September, whereas those of other broods remained unaltered except, as might have been expected, at the ingathering of harvest. The birds became as wild as hawks, took wing directly I appeared over a hedge, and sometimes travelled long distances before they dared to alight. Later, I never found them in their old homes, but I generally managed to discover their new haunts, and there, with caution, my dogs could approach them and give me the chance of a " right and left."

Indeed till the dawn of the happy-go-lucky Boxing Day, which upset all calculations of sport, and generally ended, for me, the partridge season, I could rely on finding, among the rough pastures and stubbles of the sunny hillside, any covey I had recently flushed within a radius of a quarter of a mile. Also to a small plantation on the slope came not a few of the wild pheasants that had found discomfort in adjacent woods. As the years went by, I became 
convinced that my luck, and the extraordinary length of the season in which my setters could be worked before rabbit shooting over spaniels began, was attributable to the fact that I took the utmost care never to disturb a brood of partridges during the usual hours of feeding and resting, unless, indeed, I required to do so in studying the bird's habits, or in satisfying my curiosity as to the ways of Philip, the moorland poacher.

Many wild creatures are quickly driven to seek new haunts beyond the reach of persecution. But partridges-our home-loving little "brown birds," whose very presence on a farm is suggestive of all that is idyllic in the rural life of Britain-seem reluctant, till the "local migration" of spring becomes general, to move further than is absolutely necessary from the fields where they were reared. Their wingpower is sufficient for long and frequent journeys which would soon place many miles between them and their old homes; yet, apparently, their dispersal over the countryside is similar to that of plants, the seeds of which drop and take root only just beyond the area required for the further growth of the parent stem. The birds, however, soon recognise the significance of night attacks, from which they escape with the memory of the frantic struggle of a wounded companion, 
and with the scent of blood fresh in their nostrils. And they know, also, how impossible it is for them to abide where food cannot be obtained without continuous dread. The "moucher," sweeping the coveys by night, or shooting at them while they feed and " jug " in the stubbles at dusk, does far more mischief to the game preserver than may be occasioned simply by the loss of half a dozen brace of birds. 


\section{THE PARTRIDGE}

\section{IV \\ The Changing Year}

TTHE partridges of the moorland fed, like 1 the grouse, on young shoots of herbage, tender seeds, and all kinds of soft-bodied insects; so also did the brown birds of the lowland. The partridges on the wild mountain-side, during periods of summer drought, were often compelled to travel considerable distances in search of food and water, and sometimes a shepherd found a dead chick under a heather spray beside a stony path-mute witness that little limbs had failed by the way, and that the sun had not only given, but also taken, the sweet fresh life of the year's late morning.

But the habits of the partridge on the old carpenter's farm were slightly different. The same sun that shone unpityingly on the famished weakling of the mountain waste was not the giver of death to the birds in the lush valley stretching to the hills around the hamlet by the brook. These loved the summer heat, which, while seldom parching the cultivated fields, 
hatched countless insect swarms, ripened the seeding tops of corn and grass, and caused the red and purple berries to swell to full maturity on hawthorn and bramble in the thickets of the hedges. And even the longest drought failed to dry up the waters of the brook.

Winter, too, was less distressing to the birds in the sheltered fields around the farm than to those in the barren wilderness that, on the far ridges of the grey horizon, fronted the rough tempests from the north. Even the adult partridges of the uplands, so trained by hardship that they gleaned and were satisfied where the partridges of the valley would have found nothing fit for food, often succumbed to the rigour of mid-winter. But, except in some long season of severest cold, the lowland birds obtained sufficient provender with ease. They suffered more in rainy weather, in the choking fog of an autumn night, or in the drenching thaw following severe frost and snow. Often after the mountain had shed its rainfall in a hundred trickling rills through gorge and dingle, the valley, despite its deep and thorough drainage, held the moisture as in a broad and shallow receptacle from which vapour and flood alike could find no means of escape; and often, when clear sunshine or moonlight lay on the breezy mountains, a pall of thick darkness hung over the low-lying fields, 
where the great silence was broken only by the voice of the turbid brook.

Nests of brown and black and yellow ants were numerous in the rough pastures and untrimmed hedges near the farmstead; and of the many trifling delicacies in the partridges' bill of fare none was more highly prized than were the larvæ and pupæ found in the chambers hollowed out by the industrious insects to form their underground abodes. As spring advanced toward summer, and when most of the "neuter" population in each mound had hatched out, the small pupal forms from which they had emerged gave place to the much larger grubs intended for development into "perfect" males and females. These larger "ant-eggs," as the country people ignorantly called them, were for the partridges a tasty, rich, sustaining food; they represented the very essence of the soil and the air, first absorbed through the life of a plant by Nature's alchemy, and then transformed into the bodies of insects.

The lives that had their being in those chambered mounds at the roots of the grass were, perhaps, even more wonderful than were the lives of the feathered pillagers. After years of ceaseless observation in field and wood and by the riverside, I can suggest no more entrancing occupation for a lover of Nature than the study 
of sociable insects, among which the first place might safely be given to ants. The spectacle of an ants' nest, robbed and ruined by a wandering covey of partridges, is always to me a subject for profoundest thought. The habits of birds are, indeed, at all times full of interest, but I venture an opinion that the intelligence of ants is above comparison with the intelligence of birds.

As summer passed, the ants' nests that had escaped detection by the partridges became the scenes of extraordinary labour. Hunting parties of the "neuters" scoured the neighbourhood of each hidden home. They would attack, in a body, a creature much larger than themselves, and, surrounding it, would strive to bite through its joints, and inject the poisonous acid with which they were armed. Or, spreading out like a pack of eager hounds " in full cry," they would chase untiringly through the grass some little quarry that, aware of imminent peril, scurried with utmost haste to a distant retreat. Others, like jackals, would await the pleasure of some animal or bird of prey feeding on its victim, and then drag homewards the remains of the feast. And others, again, would climb the trees and the bushes, to filch the nectar distilled for them by the patient aphids from the juice of leaf and stem. Whether at home among the 
dim nurseries, or abroad among the radiant summer fields, the ants spent every hour of day and night in preparation for the annual exodus of the young swarms.

Presently, when the population of the formicaries had become congested, that exodus began, and teeming multitudes of winged males and females issued from the holes in the mounds. Generally the males came first, scores of diminutive "neuters," their jaws wide open, driving them up the trees and twigs and stalks that there they might stretch their wings in expectation of the flight of the females. As these virgin queens, daintily fluttering, like the males, to the extremities of stalks and leaves, whence they could quit their foothold without risk of damage to their gauzy fans, rose singly into the air, the males near them also left their restingplaces, and mounted in swift rivalry far up into the air till lost to view in the dazzling sunlight.

For a time before these swarming movements, and also while the movements were in progress, the partridges cared for little else besides the bountiful insect food which they so readily obtained. But afterwards, when the queen ants, scattered over the country-side, began their work as founders of separate colonies, and when the season of exodus was over in the populous insect-cities that had been their home, 
came autumn, when fruit and seed were everywhere strewn in the grass, and when "caterpillars innumerable" climbed down from bush and tree and sought their winter quarters to prepare slowly for the perfect life of spring.

For many kinds of insects, the year is made up of only two seasons, the one, a brief summer of rapid growth and momentous change, and the other a long winter of continuous sleep. Their summer consists of the three warm months; their winter stretches from August to May. But among the less fragile forms of life which are able to endure the slight frosts of late spring and early autumn, hibernation is postponed till after the fall of the leaf, and it lasts only till the buds again burst open on the boughs.

Long before the great autumn change, when myriads of familiar creatures seemed suddenly to vanish from their accustomed haunts, came corn harvest, with a swifter and more bewildering alteration in the aspect of the countryside than that occasioned previously by the mowing of the hay. While Twm with his assistantreapers worked in the cornfields of the valley farm, the partridges there were not exposed to such peril as in the meadows when the mowing machine, in irregular, narrowing spirals, moved along the edge of the waving grass; for the methods of corn harvest adopted by Twm and 
his fellows were almost identical with those in vogue a hundred years before. The scythe with its curved "cradle" had not yet given place to the reaping and binding machine; Twm, with clean swinging stroke, began his work on the margin of the field, then, behind him and on his right, the next labourer stepped into place, and after him his fellow, till the slanting line of reapers was complete, and the stalwart toilers advanced in order towards the further edge.

Thenceforth, for a week, the harvesters came daily to their task as soon as the sun had dried the dew on the corn. At first the partridges, when they heard human voices on the edge of the oatfield, and the frequent swishing sound made by the men in sharpening their blades with greased and sanded wedges of wood, were more curious than alarmed. But as, at intervals, the noises continued, the birds gradually retired, crossed the hedge, and wandered leisurely into the furrows among the cool green turnip leaves. In the evening, as was their wont, they returned to the oatfield. The labourers had well-nigh finished the work of the day; only a few swathes remained uncut beside the hedge. In alarm, the partridges returned to the turnips, then, by easy stages, made their way to the shelter of the barley at the lower end of the green crop, where, unmolested, they fed and slept within little arch- 
ways of the yellowing stalks. Every morning in their wanderings the birds observed new signs of denudation among the fields, till at last even the barley beyond the root-crop had been cut and garnered. Now, apart from the copses and the brakes of ferns and furze and bramble where they could not as a rule obtain the food they most desired, the only places in which the partridges remained close hidden as they searched for seeds and insects were under the big leaves of swede and mangold, or amid the patches of clover springing up here and there in the stubble. For a time, after harvest, the shorn lands seemed so utterly desolate that the covey dared not visit them when the sun was high. Occasionally, however, towards dusk, the boldest of the birds ventured a little way out from the hedges to pick up the grains shaken by the busy harvesters from the sheaves, but generally they kept to those spots on the farm where conditions had not recently undergone a change.

In the crisp, calm autumn days, they were often startled by the loud report of a gun. Occasionally, as soon as the noise had died away, a rabbit would be seen hastening across the pasture to its burrow in the hedge; or, at other times, a covey from an adjoining farm would fly in consternation to the root-field, and, notwithstanding many attempts on the part of the 
original occupiers to drive them out, insist on prolonging their stay till twilight, when they cautiously withdrew to their accustomed feedingplaces.

In the middle of November, when, in the sheltered valley, the leaves of the oaks had changed from green to yellow but not as yet to brown, and when on the ash-trees the sere seedclusters still clung to the slender twigs, came the first heavy snowstorm of the year, and for hours the landscape was veiled by the close-drifting flakes. In the afternoon the storm ceased, the air became colder and still colder, and silence brooded over the fields. At evening, across the blue and yellow sky floated round grey clouds, their edges touched with pink, the crescent moon hung pale and lifeless above the hill, and the wide expanse of gleaming snow reflected the hues of the heavens. The glassy brook-pools down among the rime-fringed reeds also mirrored, but more clearly than the crystalled snow, the colours of the dome. As the splendour of the early winter sunset brightened, and glowed like liquid fire, then faded, and was succeeded by a cold white mist moving slowly along the western hills beneath the dark indigo roof of night, the deep silence was broken by the loud carols of the robins, the hoarse notes of a carrion crow, the frequent cawing of rooks on their way to the 
woods beyond the nearest hill, and the incessant, angry twittering of hedgerow birds whose warm night sanctuaries in holly and gorse bush were being invaded by strangers that could find no protection from the cold among the bare hawthorns where they had usually slept. All these sounds, even the songs of the robins, seemed mysteriously in accord with the desolate aspect of hillside and valley.

Under the snow-laden gorse, the partridges obtained a frugal meal of seeds and hibernating insects by scratching away the shallow soil covering the upper roots of the sapling trees. The darkness deepened, the moon's ashen light gleamed on the white waste, one by one the stars peeped from the cloudless sky, and every voice but that of a robin still singing by the brook was hushed. The hare left her "form " in the hedgebank, and leisurely set forth on her night's lonely journey; and, along the margin of the thickets, the rabbits played with one another, or, after clearing away the snow from favourite little patches of clover, nibbled the crisp leaves exposed to view. The partridges, having with difficulty found sufficient food and for that reason prolonged their stay in cover till nightfall, settled down at last on the leeward side of some reeds in the rough pasture below the wheatfield; where, an hour later, a poacher, setting 
snares for rabbits in the runways of the hedge, saw them together asleep, but without disturbing their slumber went his way.

The snow, hardened by successive frosts, remained on the ground for more than a week, and many animals and birds, unable to obtain food except at noon when the sun brought on a slight thaw in places screened from the wind, suffered from privation. The partridges, ready at once to adapt their habits to a change of circumstances, now frequented the borders of the woods during the morning and the afternoon, instead of roaming in the open fields, where, against the white background of the snow, their movements could have easily been followed. While occupied with their toilet, or sporting with one another, or looking for stray insects and berries near the tangled undergrowth, they were quick to take alarm, and if they suspected danger would scatter each to a particular retreat, and squat, moveless, among the protecting twigs. Always, however, when the sun was warm and the frost began to melt, they would steal away together, along by the south side of the hedges or of the high-road, where the crust of snow was often melted by the heat and pressure of waggon-wheels and horses' hoofs, and search for the miscellaneous provender which now sufficed to allay their hunger. Thence they wandered down the valley to the brook, 
and, among the willow roots beneath the arching bank, sipped from the swift-flowing stream that, even in the severest weather, was never entirelv covered with ice.

Every action of the partridges, till the fields again were moist and green, seemed to be guided by a marvellous intuition of peril. Exposed to view if they dared to walk or fly across the snow, they were also often in danger when they frequented the sheltered hedges. For there, many others among the hunted dwellers of the field, when sorely in need of food and warmth, foregathered, and birds and beasts of prey were not slow to observe the opportunity thus afforded them, and to mark especially the spots frequented by the well-conditioned partridges. 


\section{THE PARTRIDGE}

\section{V}

\section{A Day with the Partridge}

TOWEVER inclined we may be to hold 1 tenaciously our own opinions, we surely should recognise, in common fairness, that the ideas of other men are worthy of respect. But nowadays, even in field and covert, sport threatens to partake of the nature of an exact science, and many good sportsmen rebel against the change, and long for a return of methods and conditions associated with the past. Rather ungenerously, perhaps, these sportsmen blame the Master of Foxhounds who hunts his fox in a way to please a fashionable crowd that at all costs will "go the pace." An enthusiast of the old-fashioned school is wont to protest that there is nothing in fox-hunting nowadays but "pace." When he was young he loved to see the hounds match their intelligence against Reynard's many wiles, and to enjoy the winter beauty of the countryside, as much as he loved the long, hard gallop and the excitement of leaping bank and ditch. Now, in his opinion, 
a fox-hunt is a steeplechase, and any element of uncertainty afforded by Reynard might as well be given by a man riding a devious course and trailing a red herring at his horse's heels. Indeed, says our disappointed sportsman, it would be well at once to recognise the extinction of the fox and make the hunt a "drag," for then the Master could privately arrange his course to the satisfaction of his followers.

The old-fashioned sportsman is equally bitter against the changes which have taken place in the shooting-field, but these changes are inevitable, while those in fox-hunting are, to some extent at least, a matter of choice. In most districts of England the farmer "cleans" the harvest fields and trims the hedges and the ditches so thoroughly that there no bird or beast can remain unseeing and unseen; consequently new methods of shooting game have been devised.

Not long since, while reading what is supposed to be a clever work on shooting, I could not help remarking how strange to me were the phrases the writer used, how bare and uninteresting seemed the facts, how into every page had crept the luxury and the artificiality of twentiethcentury life. It appeared to me that the writer considered the charm of partridge shooting to lie entirely in the act of bringing down a fast- 


\section{A DAY WITH THE PARTRIDGE 189}

driven bird, in making a record " bag," in doing something to create a stir among the men with whom he associated at his host's table. And at the end of the treatise, he, in mood like Alexander sighing for more worlds to conquer, complained that partridges were not reared in sufficient numbers on the estates over which he shot, certain little corners of the fields having been left untenanted by birds that should have nested there. In vain I looked through that treatise for the least indication of the finer feelings of humanity-I might as well have scanned the pages of a gunmaker's catalogue. But the picture in my mind as I closed the book was such as no catalogue has ever suggested-a picture of wounded birds left for hours to struggle in their misery around the butts, till the keepers arrived on the scene to count and collect the spoil.

Luckily partridge shooting, here in remote districts of the west, may still be made to yield precisely the kind of sport that our fathers and grandfathers enjoyed. We bring up our pointers and setters in the way they should go, and though the modern "twelve" has taken the place of the muzzle-loader, and we do not venture out into the fields wearing long-tailed coats and "chimney-pot" hats, incidents very similar to those chronicled by our ancestors 
form the subject of the entries in our gamebooks. The farmers over whose lands we shoot adhere to old methods of husbandry, and sufficient cover exists for birds to lie in imagined security before our dogs. May the day be long distant when setters and pointers shall never be seen in the fields around my home!

If only for memory's sake, I must needs go forth into the autumn fields, and take the long windward beats from hedge to hedge, while my dogs, obedient and sure as they and their kin have ever proved to be, range over root-crop and stubble, eager to scent the hidden covey. As I walk in my Arcadia, that since my childhood has ever yielded new delights, I see, from the hills, a little straggling village by a river, with white pigeons circling about a dove-cote near the bridge, and sunlight gleaming on the gardens ; I hear the rumbling of laden wains along the street, and even, if the wind be from the south, the sound of voices as my neighbours wander down the river path. In the fine air of the autumn morning every sound is distinct, like the chime of sweet-toned bells; all objects before my eyes seem brilliantly near.

I am brought to a sudden halt; Cora, my Gordon setter, is at point in the middle of the field, close to some ungarnered sheaves of wheat. The "old lady," as my children call 


\section{A DAY WITH THE PARTRIDGE 191}

her, seldom makes the least mistake. I was not her trainer; she came into my possession when all but the finishing touches had been put on her education, and some time passed before I learned her ways, or taught her mine. I soon decided, however, that Cora needed unusually gentle treatment to make her a good sporting dog. She differed greatly from any dog I had previously possessed, and had evidently been hardly used in puppyhood. She dreaded the sight of a whip, and cringed and trembled at a single angry word. But by patience I found out most of her little peculiarities, how to humour certain of her whims and to control others; I found, also, how, by praising and coaxing, to lead her to comprehend that many of her duties were well performed. How faithfully she has served me! Hundreds of times she has ranged the autumn fields and the wild stretches of the winter moors, and always, obedient as a child, and faithful as only a dog can be, she has delighted in the work for which her training fitted her. Cora is old now; the jet-black hair of the muzzle and around the eyes is plentifully streaked with grey. Her reputation is great in the village and among the farmers on the countryside; but a stranger, seeing her trot before me down the street, would hardly take her from me as a gift. "Handsome is as hand- 
some does ;" as the old Gordon stands staunchly on her game, with her almost hairless "flag" outstretched, one almost hairless paw uplifted, and lips and nostrils quivering with excitement, she needs none of the silken beauty that adorned her in her prime to increase my admiration. Steady! old lady; the birds are not wild to-day; I need not hasten to your side.

Moving leisurely towards Cora, I catch sight of Random, my big Irish setter, standing motionless away to my left. He has taken in the situation at a glance, and is backing his companion from a spot behind a wheat-stack. Anxious for him to remain on his best behaviour I raise my arm; and at the signal he sinks slowly to the earth and rests his head between his paws. I go a few steps further, and with gun in readiness stand behind the old Gordon. She welcomes me with a single movement of her tail, and tells me plainly, with one serious look from her dark brown eyes, that business is to the front; then strikes an attitude slightly stiffer, if possible, than that which she had first assumed. With a gentle push of the knee, and a whisper of command, I send her on to " seek." She moves a yard, and another, and yet another, crawling on the ground. She stops; not another inch will she advance. I end the suspense by stepping forward, the whir of many wings breaks 


\section{A DAY WITH THE PARTRIDGE 193}

the morning stillness as a strong, full-grown covey flies up almost from beneath my feet; two loud reports ring out, and the sport of September is begun with a clean, well-distanced right-and-left. For a moment I wait, calming the excitement which both my dogs, though trained to "drop to shot," must keenly feel ; then, cautioning Random to remain at " point," I give Cora the signal to "seek dead." She ranges slowly ahead, careful lest some straggler from the covey still waits to be shot; and presently "sets" on the dead birds, which I retrieve and deposit in my ancient game-bag. Then Random is whistled " to heel," and soon both he and Cora are sent off again across the winc.

W here now are the dozen birds that survived the peril of the gun? Doubtless they have flown to the root-crop beyond the near meadow. Later, on the down-hill beat, Cora and Random will find them again. The stubblesmall as are most of our fields in the westyields nothing more towards the bag. I climb the hedge, walk over a pasture where the dogs are rested, because no cover exists for game, and reach a second stubble. Cora trots away to the left; Random gallops to the right. Quickly they turn and are almost crossing when the Irish setter checks his headlong career, tries a back- 
ward cast, then works inquisitively up-wind, with tail held low and swaying gently from flank to flank. Off once more he gallops as far as the hedge, returns, passes Cora, and checks on the line of scent that he had previously detected. But this time he works further into the wind, is uncertain only for a moment, and then stands rigid. Almost before he comes to point, Cora is " down" in the ditch, watching him eagerly, but not daring to move.

Boisterous Random needs firm handling. $\mathrm{He}$ is not free from the failings of his careless puppy days, and would dearly like to catch a rising bird rather than see me shooting it. Nevertheless his temper is of the sweetest, his power of scent extraordinary, his speed and style are such that Cora could never hope to rival him had she not the experience of many an autumn day to aid her in her quest. Random, in brief, is a type of the rare combination of the show dog with the worker. "Live-stock" journals have vied with each other in describing his appearance on the "bench" ; critics, promising for him a career of triumph in the field, have sought to win him from my ownership. But Random, the rollicking pet of the household in the valley, is neither for mart nor exchange.

Luck is not with my wild Irishman in his first find. A "cheeper" brood, too weak and small 


\section{A DAY WITH THE PARTRIDGE 195}

to tempt my gun, flies up, hastens towards the hedge, and alights in a corner of the field amid a rough tangle of briar and gorse. Fortune comes a few minutes later. A "barren" bird dashes out from the ditch, and is "grassed" on my second barrel; and immediately I reload; and her mate offers the easiest of shots as she flies along by the hawthorns.

Afterwards sport slackens; sometimes I try to pick out the old birds of the covey, and fail, or the young partridges are so small that the gun hangs at the trail instead of leaping to the shoulder. During the afternoon, in a turnip field where partridges are scattered, both dogs work exceptionally well; and strong, quick birds are flushed, and dropped with a precision which I by no means frequently attain. After an uneventful hour, another scattered covey is surprised. Then Random and Cora, tried by their hard work beneath the broiling sun, begin to show signs of fatigue, so I call them to me, and rest beside them on the stubble till evening pales in the west, and the ke-wheet, ke-wheet of a partridge that has lived through the experiences of the day sounds faintly from the hill-top, and seems to remind me that, like a true sportsman, I should leave the birds in peace at supper-time.

The westering light gleams on my study window far across the river valley. Perhaps, 
on the grass beneath that window, a budding sportsman and a little, white-frocked companion who already has tastes of her own and loves a fox-hound and a setter dearly, are waiting for my tale of the day. 


\section{WILD LIFE IN HARD WEATHER}

BITTERLY cold days, overhung with a light mist that vanishes at noon, but in the dusk of morning and evening floats like a dim blue film over the red sun, and still colder nights, bathed in unnatural brightness by the moon and stars, have succeeded the rainy weather that accompanied the advent of winter. Hardened by frost, the snow lies thick on the fields. All the broad pools of the river are icebound. To the fast-flowing trout-reach below the bathingpool an otter comes every day at noon to fish the stretch beneath the cottage gardens. If only the watcher remain motionless and silent, the creature continues a systematic search from bank to bank, now and again showing itself at the surface when it rises to breathe. Forced by hunger to abandon many of its wild ways, the otter is sometimes seen at night in the lane at the end of the village, whence it is chased back to the river by any wandering terrier which may chance to cross its path. Its favourite resorts are the refuse heaps in the gardens and beyond the high wall built as a breakwater against the 


\section{WILD LIFE IN HARD WEATHER}

river floods. During long-continued hard weather every fish in the river apparently vanishes. The trout are there, however, though not visible. They have forsaken the streams for the still pools, where the temperature beneath the ice is not so variable as in the open water among the rapids. The otter, unable, because of the ice, to drive the trout from their hiding-places at the bottom of the deep pits they frequent, is forced to feed on anything it may find in the streams -an occasional "kelt" salmon, or salmon "pink," or a stray morsel from the cottagers" kitchens-and finds the bill of fare well-nigh a blank. Yet fortune sometimes favours it. A half-pound fish, chased by a cannibal of its own tribe, will now and then drop down from the hollow of the pool to the shallows, where the ice becomes thin and at last disappears on the edge of the rapids. Here, if anywhere, a stray " blue dun " is to be found loitering at the surface in the brief sunlight of the winter noon. The trout know this, and lurk among the ripples for half an hour in the warmest time of the day. The otter, learned in all the ways of its prey, has forsaken its nocturnal habits, and spends most of its time on the look-out for roving fish by the fringe of the ice.

Around the trunks of the willows that grow by the river are cleared spaces where the water- 
voles have scratched away the snow in their quest for food. Under the trees the ground thaws more rapidly than elsewhere; the latent heat in the trees themselves is, in part, the cause of this. Finding the earth comparatively soft close by the willows, the voles have here and there dug a shallow trench, that they may obtain a frugal meal of grass-roots and reeds. They are timid little creatures; their burrows by the waterside are like miniature dwelling-places of the otter, one entrance opening on the top of the bank and the other below the surface of the stream. In summer the voles are rarely seen by day, but when darkness falls they sit out with their families near the reeds at the margin of the river. At the slightest disturbance they drop into the water and enter their burrows by the hidden passages. Like otters, they are nightfeeders. But hard frost causes a change in their habits; they now take full advantage of the warmth of noon. In the least thaw the voles must work hard, if life is to be kept aflame. Perhaps only for a little while in the day can the hungry creatures have easy access to the succulent shoots of water plants and grasses which form their simple diet, and then, in certain unfrequented places, they throng the river bank.

None but the student of Nature recognises how marked is the change in the life of the fields 


\section{WILD LIFE IN HARD WEATHER}

after a week of uninterrupted frost. An unforeseen catastrophe has befallen the weaklings of Nature's flock. No sufficient provision has been made to meet the sudden cruelty with which an erstwhile bountiful hand turns the key that closes the storehouse door. Disinherited and forlorn, the wild wanderers by wood and hedgerow eke out a bitter existence in mute appeal against the inexorable fate which has driven them forth upon the bleak face of a barren world. When the mildness of our climate is rudely disturbed by piercing east or north-east winds succeeding a fall of snow, the conditions of life in our temperate latitudes are similar to those existing in Arctic regions. But the habits of our wild creatures are different. Along lines of migration known for ages, Arctic birds and animals move southwards in the dusk of the darkening winter night. Once arrived at their usual resting-place, they for some unaccountable reason seem disinclined to journey further south.

Overtaken by unexpected severity of weather, redwings and fieldfares die in thousands from privation and cold. One morning, in a recent winter, thirty-three of these birds were picked up dead on a small farm of forty acres. Even our native birds suffer greatly from any unusual continuance of cold. Wood-pigeons, among 
the hardiest of forest dwellers, collect in large flocks and associate with the stronger-beaked rooks. The sable legions fly from field to field, and by unremitting labour among the furrowslabour directed by shrewdness and intelligence -manage in places to tear up the ground and obtain the necessaries of life. The cushats watch the resourceful rooks, and in the fresh-turned earth find here and there some welcome morsel rejected by their companions. But the woodpigeon is no longer the plump, fleet-winged bird that filled the summer wood with soft and ceaseless cooing. Wasted by privation to a mere bag of bones covered with feathers, it wearily wings its way to the home meadows, and there alights to pick a meal from the turnips provided by the farmer for his hungry sheep.

By the river-side, the water-vole, as well as the pigeon, discovers in the ubiquitous rook a friend. The rook is a keen entomologist. Ponderous books would not suffice to contain all the knowledge of insect life possessed by the tribe-father of the rookery on the hill. In the mysteries of pupa-digging, college professors are as novices compared with the ploughboy's black attendant. Every tree in summer sheltered amid its leaves a hundred little families of promising caterpillars, destined, if fate were propitious, to develop into delicate, soft-winged 
moths. When autumn came these caterpillars spun their robes of silk and passed into the third, the sleeping, stage of their existence. With the fall of the leaf they dropped to the ground. Some, however, when about to sleep, crawled down the trunk and burrowed in the warm soil at the roots, before putting on their garments of "chitine." All this is known to the observant rook. In the thaw of the winter noon the wise bird comes to the foot of the tree, digs beneath the snow among the rotting leaves, and, foraging for the hidden grubs, assists unconsciously the little vole to hollow out a shallow trench around the trunk.

The increasing cold of night drives every creature to cover. The rooks forsake the elms on the slope for the oaks in the valley below, where they cluster together almost as closely as leaves. Hares and partridges lurk in the furzebrakes near the haunts of man, and at dawn steal through the gaps into the home meadows, to join the pigeons among the turnips or to pick up stray grains near the feeding-troughs. Blackbirds, thrushes, and finches collect in the thickets for shelter from the bitter wind. When morning comes they, too, join the wood-pigeons in the fields near the farm. The pheasant goes to roost in the middle of the larch plantation. Shyer than the partridge, the forest-bred "long-tail" 


\section{WILD LIFE IN HARD WEATHER 203}

trusts to the woodland sanctuaries, and there, during the day, searches the tangles on the outskirts of the trees for acorns and berries.

Many creatures now become torpid. Others fall into a state of lethargy from which the call of hunger every day arouses them. Except when thus awakened, the weasel, stoat, and polecat lie curled up in the furthest corner of their burrows, doubtless longing for winter to pass away. Like the otter, they abandon some of their wild ways at this season. Occasionally the stoat is seen to peep from a hole in the farmyard wall, when hunting the rats that have entirely forsaken the fields to take up an abode in warmer quarters.

The members of the weasel tribe, were it not for the rats and mice at the farm, would find it difficult to live through a long period of frost. The keen air of night benumbs them. After dusk they seldom, if ever, venture forth from their burrows. By force of circumstance the habits of all three animals are changed. So sensitive are these creatures to cold that they choose the warmest part of the day for a visit to the neighbouring warren or corn-stack. But at that time the rabbits are generally abroad, enjoying the slight thaw; and the stoat and polecat have no alternative but to pursue them through the furze or along the hedgerows. Such 


\section{WILD LIFE IN HARD WEATHER}

a hunt is seldom successful, unless time be at the disposal of the hunters. Yet in the afternoon, should the rabbits be driven to their burrows, the raiders find their task an easy one, for, caught in blind alleys among the galleries below ground, the timid rodents choose rather to submit to death than by one bold effort to make their escape.

5. No satisfactory reason can be given for the paralysing fear that possesses the rabbit directly it ascertains the presence of a stoat. Nor can it be explained why the rabbit should "bolt" before its cruel foe more readily in the morning than in the afternoon. For ages, from causes which evolutionists have clearly described, those creatures most capable of taking care of themselves have outlived their weaker and less intelligent brethren; and, bearing this in mind, we cannot understand how a strange stupidity, which so often results in death, can have become hereditary.

In hard weather the fox and the hawk approach the homestead. The kestrel descends suddenly, like a stone dropped from the sky, into the barnyard, and rises with a mouse in its claws. The sparrow-hawk, bolder and more cruel still, dashes along the hedgerow and "stoops" upon a thrush that is trying to get at a worm in the "miskin" near the cowsheds. 
At night, when the unclouded moon shines from the indigo sky with a strange, weird brightness upon the white coverlet of the sleeping world, the fox steals through the shadows of the woods and enters the fowls' house at the farm. Presently, awakened by the cackling of the poultry and the barking of the dogs, the farmer appears at his window. A shot rings out into the silence. Stung by a stray pellet from the old muzzleloader, Reynard drops his prey and, followed by the loud-tongued dogs, disappears within the woods.

Unsoiled, save by the firm footprint of some lone labourer on his cheerless way to a neighbouring farmstead, the snow covers the village street completely. Regularly each night the flakes are wafted by the wind against the southern side of walls and hedgerows, and there heaped in drifts which, lit by the grey light of early morning, glisten with a soft, pearly splendour like that of the hovering mist above the curtained river-fall in the gorge. Fantastic traceries, as of crystal pine trees, or like festoons of flowers hung upon columns and archways, are outlined on the window panes. When the sun tops the hill, these become merely dainty incrustations, having the appearance of obscure cathedral glass, with fragile borderings which slowly melt into radiating spangles, and increase 
in transparency and beauty till they fade away. Then the cold world without, of village street and open field beyond, is plainly visible, all mantled in the riftless snow. Meanwhile, before the shafts of sunlight strike the window panes, the grey, leaden sky changes and assumes the colour of dull yellow. The vapours of the frost, warmed by the risen but invisible sun, are distilled from the meadows in a dense cloud that hides the towering woodlands of Dol'llan.

Directly the thaw begins, the coldness of the morning seems to grow keener than before, since cold is more penetrating in a damp atmosphere than when the air is dry. During a thaw the air is laden with moisture to such a degree that, if we stand still in the shade for any length of time, our limbs become almost paralysed. Earlier in the winter, night after night, a dense hoarfrost, rising chiefly from the river and the adjoining water meadows, closed like a pall over the valley. High on the slopes, beyond the level of about a hundred feet above the river, this unusually dense hoar-frost was not felt; when morning gilded the crests of the hills, the sun shone uninterruptedly on the dry and supple verdure of the uplands. But, within the fringe of the great mist-cloud, every blade of grass, every tree, and every stone were set stiffly in a jewelwork of frozen dew; light almost failed to 
WILD LIFE IN HARD WEATHER 207

penetrate the dense rolling waves of gloom; and the very breath of the field life seemed stifled by the heavy pressure of the humid fog-wreaths. Then the cold was felt to be terribly severe, and the raw dampness of the atmosphere chilled one through and through.

As the morning advances the dense mist of the frost is lifted by the growing strength of the sun above the water meadows, and there, collecting in a dense cloud, rolls past the wooded slope. Soon, when the sun is high above the wood, the cloud dwindles into a thin streak of blue fog, which lies across the tree-tops near old Watty's cottage at the entrance to the glade. This fog, rent at its edges by innumerable shafts of ruddy light, disappears at last; and the bright, unclouded azure of heaven extends in a great inverted cup that rests on the rim of the moorlands, on the rugged crests of the far-off mountains, and on the gentle undulations of the sleeping upland pastures-all a dazzling irregular horizon of untrodden snow. Simultaneously with the departure of the cloud from the wooded slope near the river, the fairy fretwork of the rime-frost vanishes from the stiffened boughs, and the moisture drips from the pendent twigs. Sometimes it trickles down the twigs, and, meeting on the main branches, forms rivulets that in turn become united where the branches 


\section{WILD LIFE IN HARD WEATHER}

join the stem; thence the melted frost flows in one broad stream down the furrowed bark, and, penetrating the snow, nourishes the gnarled roots outspread beneath the soil.

As I leave the village by the hard, slippery path leading to the woods, the voices of street and farm mingle with those of the fields. A babel of sounds-the cackling of poultry, the cooing of pigeons, and the lowing of cattlereaches my ears from the neighbourhood of home; while near me, on the shelving rocks by the river, a dipper sings cheerily as he splashes and runs through the ripples; and still nearer, hopping in and out of hawthorn and ash, then hiding in the " trash" that still clothes the fence, a lively wren, undismayed by the piercing cold of the winter morning, trills his loud, audacious lay-disproportionate as coming from such a diminutive songster-and searches every likely spot for the tit-bits of the day's first meal.

The wren is ever an optimist; in summer and winter alike he is the same cheery philosopher, apparently revelling, with a keen eye for humour, in circumstances which to others bring despair. His actions are my only guide, however, and though, like " the merryman, moping mum, who sang because his heart was glum," the wren, in his comical postures and whimsical ripples of gladness, may possibly hide with a mask of 
burlesque those troubles, in the scarcity of food, and danger from frost, which are brought him by the keen breath of the winter wind, I cannot, somehow, imagine that his indifference to adverse conditions is assumed. Since childhood, I have thought him possessed of a stout heart in a tiny body, and with a strong, cheery voice fit to proclaim his happy-go-lucky philosophy. Like the hedge-sparrow when in full, unhesitating song, the nut-brown wren commences his outbursts of joy with a high, shrill note followed by a rapid, rollicking phrase. The wren sings all through the year, except just after midsummer, when, as if he noticed the lengthening shadows on the grass by the hedgerow, he is silent for three or four weeks, till, with the ripening of the golden corn, he finds again that philosophy which was in winter the secret of his merry life. No wonder that the old Celtic bards loved the wren, and his fellow winter songster, the sprightly redbreast! According to the old Cymric saying :

"Pwy bynag dorrith nyth y dryw, Ni chaiff weled gwyneb Duw."

(He who breaks the nest of the wren shall not see the face of God.)

Whereas the wren's music perpetually displays the spirit of a bohemian, the robin's carol often betrays a minor undertone of pensive melancholy, and recalls the beauty of a past summer, 
instead of promising that a similar loveliness will shortly rest on the fields.

Vast flocks of wood-pigeons wheel above the trees from end to end of the wood. They pass between the clumps of Scotch firs, and, as they settle simultaneously on the leafless branches around their favourite roosting-places, the fluttering of their wings seems for the moment like the erratic spinning of a thousand slate-blue leaves. Having alighted on the tallest twigs, the cushats are conspicuous, like points of pale light, against the sombre background of the leafless oaks. Restless, they do not stay for any length of time in one place, but soon move off, and wheel to and fro along their previous lines of flight. Their strange restlessness is, no doubt, induced by hard weather. The cushats have failed to procure their food; till noon the iron grip of the frost holds the woodlands, and denies to myriads of hungry birds their meagre winter fare. Even the jackdaws and rooks are unable to obtain a meal; but here and there the carrion crows, wily and omnivorous, find at the margin of the stream a few scraps of refuse wherewith to satisfy their eager appetites, and the lapwings, having come down from the moors, are busy in places where the frost is not so keen as elsewhere, and a trickling brook, hastening to join the river, overflows its muddy banks. As I pass onward, 
two or three snipe, with feeble notes of alarm, rise quickly from the reeds beside the brook, and, on pointed pinions, speed away towards the Cerdyn valley. Then, with a sudden change of flight, they top the woods and are gradually lost to sight in the far distance of the sky.

Noon draws on, and the snow disappears from the open fields and from the hillsides facing the sun. The pigeons leave the pines, and settle to feast on the acorns which the sun has exposed among the open spaces in the oak-scrub, and among the low-lying meadows in the hollow of the valley. Their habits, perforce, are changed with altered conditions. Now, instead of feeding in the early morning and again towards sunset, the pigeons must be content with little more than their noonday meal. Their eagerness in procuring the day's provender is more marked than in mild weather. As the afternoon approaches, the flocks divide; henceforward the pigeons congregate only in parties of twenty or fifty at most. If fortunate in finding plentiful supplies of food, they return to the pines about two hours after noon, leaving behind them those which have not been successful. Thus, a continual stream of birds crosses and re-crosses the wooded hillsides, the satisfied pigeons betaking themselves early to roost in the firs, and the hungry birds still wandering from place to place 


\section{WILD LIFE IN HARD WEATHER}

in hope of discovering some hitherto unexplored locality in which the fleshy acorns lie strewn beneath the trees. Since the first of the frosts occurred, I have noticed this decided change in the habits of the wild pigeons.

Somewhat similar changes may be observed, in methods of obtaining food, among nearly all wild creatures; and local migration, which ceased during the mild weather at the beginning of the month, is now plainly recognised by birds, and also by certain mammals, as the surest method whereby to find sustenance, and thus to prolong life under adverse circumstances. One of the most common instances within, perhaps, more limited areas than those affected by the local migration noticeable about the beginning of winter, is shown in the altered habits of even our most familiar birds. Our woodland inhabitants, as a rule, keep to their usual habitats, for there a grateful shelter may be found when in the starry night the pitiless north-east blast, or that tingling stillness which is almost as cruel as the winter wind, brings the blight of the frost on the open fields and moors. Birds would be destroyed in countless numbers by hard weather, and the balance of life in general entirely upset throughout our islands, were it not for the sanctuaries of the woodlands. To these, in time of famine, our little friends resort as to a home where 
Nature provides a crumb for consolation and a little warmth for comfort, while the world without is being sorely tried, and the fittest only are suffered to survive.

Many birds, which in mild weather frequent the open fields, change their places of abode after a few days of hard frost. Indeed, the absence of small birds in exposed meadows is sometimes strangely noticeable. The members of the thrush and finch families are found in hundreds where before the frost hardly one could be seen. I have observed even larks and sparrows to take up their quarters in thick coverts of Scotch fir when the frost binds the pastures with its glassy fetters and leaves only the rich, loamy soil of the woodlands free.

But, while in certain respects the habits of many creatures have altered to a remarkable extent, the rigours of winter have caused, on the whole, comparatively little suffering this year among the hills. Every day in the past week has been alike-hard frost in the shade, and a quick, general thaw in the sun. And, though the daily periods of release from the conditions of famine are fully utilised by the little dwellers in the wilds for obtaining nourishment, the equally constant periods of frost are beginning to tell on the life of field and woodland. 


\section{WILD LIFE IN HARD WEATHER}

The redwings and fieldfares, our typical winter visitors from northern climes, are less shy than they were a month ago, and even a few of these have taken to the woods. As I pass along the hard, dry road at the bottom of the dingle, on which the slanting sun rarely throws a single yellow beam, I see above me, where the sunlight is breaking between the interlaced boughs on the crisp carpet of oak leaves, a redwing busily engaged, pecking at the withered heaps, scattering them, and seeking diligently and ravenously for a few morsels of food beneath. The bird scarcely heeds my approach, though the icy road rings with the clatter of my well-shod feet. When, an hour later, I return along the same path, the redwing is still among the oak leaves, but so weak from hunger and cold that I almost succeed in capturing him. Desirous of knowing a little more about the bird, I chase him up the slope, but he finally eludes me by scrambling through a clump of brambles, and I continue my walk, satisfied that the unwonted exercise and fright probably brought to the poor sufferer more good than harm. I have read of a benumbed traveller desiring to sink into slumber, and of his companions keeping him from the fulfilment of his fatal desire; perhaps the redwing, but for me, would presently have slept beyond awakening. 


\section{WILD LIFE IN HARD WEATHER 215}

I have long desired to understand why such apparently hardy birds as fieldfares and redwings, coming from higher latitudes than ours, suffer even more than our native birds during hard weather. It is a generally accepted belief that migratory birds, or their young, return to the same quarters by the same line of flight, year after year. Supposing that the redwings and fieldfares we now see are the descendants of untold generations which have frequented these fields and woodlands for countless winters -why, then, are they not inured, like thrushes and blackbirds, to the hardships they at present encounter? Disasters, apparently similar to those that have overtaken other birds, have been the lot of redwing and fieldfare; a similar process of weeding out weaklings by these disasters, and thus of causing a gradual adaptability to surroundings, has taken place. Bearing this in mind, I cannot readily account for the disproportionate mortality among the birds. Our northern visitors are doubtless affected by having to change their diet after migration. But for centuries they have been affected in the same way, and so should have become accustomed to the conditions imposed on them, in constant succession, by Nature.

Musing over this problem-one of thousands which the naturalist cannot solve-I return 


\section{WILD LIFE IN HARD WEATHER}

homewards from the woods along the riverside. As I reach the pool under the farm, a "bunch" of teal starts up from the rushes, and, with a great whirr and whistle, hurries away towards the distant gorge. Over the now quiet pool lingers the pale radiance of the passing day, and I pause for a while by the brink, gazing at the red glory of the sunset fading into the blue mist of the dusk. Near the hedge a mothering sheep, with head bent to the ground, keeps lonely watch over her prostrate, new-born lamb. From the distance comes the mournful cry of a restless lapwing. Overhead, the moon, scarcely more than half a disc, and wearing a resemblance to some cold, time-worn face, looks down on the shivering, sleepy world.

Often, in long-gone years, I have stood by the pool, looking, as now I look, towards the west, and waiting for the sun to sink behind the hill, before the big rod came into play and the gaudy salmon-fly shot out over the stream. "There, sir, 'tis all in shadow at last; now for a twenty-pounder!" Ah, I had fallen into a reverie; how clear seemed the voice of the old gillie! But that voice, except in memory, may never again be heard during my daily rambles. Let me continue my way, lest wistful fancy make the world seem colder than it used to be in those years that have now passed into silence. 


\section{INDEX}

Ants, 177-80

Birds' feeding "preserves," 38 , $88,156,159$

- songs, 46-7

Bird-watching, 32-40, 52-65, 75-7

Bittern, the, 124-38

- courtship of, 131

- fight with fox, 137-8

- nest, 133

Caterpillars, 201-2

Dipper, the, 23, 67, 78-96

- breeding, 88

- food, 89

- habits, 83-6

- nest, 92-3

- song, 78-9

Ephemerals, 22-5

Evolution, puzzles of, 204, 215

Fieldfares, $200-1,214-15$

"Fouling " scent, 150-1, 163-5

Fox, cub and partridge, 165

- fight with bitterns, 137-8

Fox-hunting, modern, 187-8

Heron, the, 74-7, 107-10, 11523

- courtship, 107

- oil of, 113-14

- training of young, 116-17, 120-3
Hibernation, 180, 202-3

Hunters and hunted, 147-8

Inquisitiveness of animals, 147-8

Kingfisher, the, 67-74

- training of young, 70-4

- winter habits of, 68

Migrants, return of, 19-20, 126,130

Migration, looal, 212-13

Moorhen, tragedy of bird life, 149-60

Otter, the, winter habits of, 197-8

Partridge, the, 139-196

- brooding, 146, 152-3

- courtship, 143-4

- fooding habits, 170, 178$80,182,184-5$

- flight, 166-9

- nesting, 145, 167

- a poacher's trick, 169

- training young, 154-6, 160

Rabbits, foes of, 162-3, 204

Redwings, 200-1, 214-15

Rook, the, 201

Shooting, modern, 188-9

- over dogs, 170-3, 189-95

Skylark, 46-7 
Sparrow-hawk, 160, 204

Spotted fly-catchor, 42

Swift, 42-3

Water-voles, 198-9

Weasels, 203-4

Whitethroat, nestlings of, 64

Willow-wren, the, 42-51

- courtship, 49

- habits, 44-6

- nest, 48,50

- song, 38-9, 43, 47, 49, 50
Wintor, animal lifo in, 183-6, 197-216

Wood-pigeons in winter, 149, $150,201,210-11$

Wood-wren, the, 19-41

- courtship, 24-5

- food, 22

- nest, 25-8

- notes, $33,37-8$

- plumage, 36

- young, 30-2, 40-1

Wren, song of, 78-9, 208-9 


\section{By A. W. REES}

\section{Creatures of the Night}

A Book of Wild Lrfe in Western Britain

THE OTTER-THE WATER-VOLE-THE FIELD-VOLE-THE FOX-THE BROWN HARE-THE BADGER-THE HEDGEHOGNIGHT IN THE WOODS.

With eight full-page illustrations from drawings by Florence $H$. Laverock.

The Times.- "So graphic is Mr. Rees' writing, the reader himself feels one of the company, crouching in the brushwood in the moonlit wood, as a crackle of twigs or a glint of light makes the stealthy motion of otter, fox, vole, hare, or badger ... these pictures of them, in conditions so seldom described, form engrossing reading for all who love the wilder aspects of nature."

Daily Telegraph.- "No one with a love of wild creatures can resist the charm of such a work, every page of which shows knowledge, insight, and sympathy ... a fascinating work."

JOHN MURRAY, Albemarle Street, LONDON, W.1. 


\section{FIELD PATHS AND GREEN LANES IN SURREY AND SUSSEX.}

By LOUIS J. JENNINGS. 5th Edition. Illustrated. 6s. net. This book will be found interesting, and in some degree useful, to those who find an unfailing source of pleasure in wandering over England, deeming nothing unworthy of notice, whether it be an ancient church or homestead, a grand old tree, a wild flower under a hedge, or a stray rustic by the roadside. It is a genuine account of personal experiences recorded, as a rule, on the very day they occurred.

\section{THE GAMEKEEPER AT HOME; or, SKETCHES OF NATURAL HISTORY AND RURAL LIFE.}

By RICHARD JEFFERIES. Illustrated. 6s. net. " Delightful sketches. The lover of the country can hardly fail to be fascinated wherever he may happen to open the pages. It is a book to read and keep for reference, and should be on the shelves of every country gentleman's library."

Saturday Review

\section{THE AMATEUR POACHER.}

By RICHARD JEFFERIES. 5s. net. "We have rarely met with a book in which so much that is entertaining is combined with matter of real practical worth." Graphic.

\section{SPRING IN A SHROPSHIRE ABBEY.}

By Lady C. MILNES GASKELL. Illustrated. Ios. 6d, net. "A beautifully illustrated book, half garden book and the rambling thoughts of a cultivated woman, half fiction and Shropshire folklore." Evening Standard.

\section{FRIENDS ROUND THE WREKIN.}

By Lady C. MILNES GASKELL. Illustrated. Ios. 6d. net. A further collection of history and legend, garden lore and character study, such as was gathered up in the former volume, "Spring in a Shropshire Abbey." 




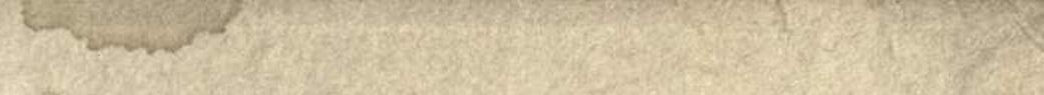


